\title{
DESEMULSIFICAÇÃO DE EMULSÕES ESTÁVEIS DE ÁGUA E ÓLEO DE GIRASSOL POR PROCESSO DE FILTRAÇÃO TANGENCIAL
}

Dissertação apresentada à Escola de Engenharia de São Carlos da Universidade de São Paulo, como parte dos requisitos para a obtenção do título de Mestre em Engenharia Mecânica.

Orientador: Prof. Dr. Sérgio Rodrigues Fontes

São Carlos 
Aos meus pais, Sebastião Roberto Del Colle e Vera Lúcia Del Colle, dedico o meu trabalho, por terem me dado todo o apoio e incentivo que precisei para conseguir alcançar mais esse objetivo. Agradeço a eles por tudo que me proporcionaram, por terem participado e contribuido para o meu crescimento; tanto como pessoa como profissional. Também ao meu irmão, Vinícius e à minha cunhada, Lígia, pela ajuda e dedicação. 


\section{AGRADECIMENTOS}

Durante a trajetória para a realização deste trabalho, pude contar com a colaboração e atenção de várias pessoas que por fim, merecem meus agradecimentos.

Agradeço primeiramente a Jeová, por ter me dado saúde e força, para perseverar diante dos obstáculos que enfrentei e poder concluir mais essa meta em minha vida. Também ao Prof. Dr. Sérgio R. Fontes, pela orientação, atenção, paciência e generosidade que demonstrou durante todo o tempo, para que esse trabalho pudesse ser concluído.

Ao Prof. Dr. Élson Longo, pesquisador do Laboratório Interdisciplinar de Eletroquímica e Cerâmica (LIEC) da Universidade Federal de São Carlos, pela colaboração e sugestões dadas durante a pesquisa e por disponibilizar reagentes e equipamentos necessários para o desenvolvimento do trabalho. Aos meus colegas Mário Godinho Júnior e Luís Presley S. Santos do LIEC, pela ajuda e atenção dadas durante todo o trabalho.

Aos técnicos do Laboratório de Termodinâmica e fluidos: Hélio, Luchesi, Donizeti, Jorge e Roberto pela ajuda na montagem e manutenção dos equipamentos usados para a realização dos experimentos.

Ao Prof. Luís Daniel, chefe do departamento de Engenharia Hidráulica e Saneamento, por disponibilizar o uso do equipamento para análise de TOC. Ao Engenheiro Luís Fernando Porto, Diretor da Cetebra Ltda - São Carlos-SP, pela confecção e doação dos tubos cerâmicos utilizados na pesquisa.

Ao Instituto de Física de São Carlos, por colocar à disposição os aparelhos usados para análise dos tubos cerâmicos. À CNPq e à FAPESP pelo suporte financeiro desta pesquisa.

Aos meus colegas de trabalho do NETef, especialmente à Renata, Grazieli, Juliana e Ernesto pela amizade e companheirismo. 
DEL COLLE, R. (2005). Desemulsificação de emulsões estáveis de água e óleo de girassol por processo de filtração tangencial. Dissertação (mestrado) - Escola de Engenharia de São Carlos, Universidade de São Paulo, São Carlos, 2005.

O processo estudado utilizou tubos cerâmicos porosos fabricados predominantemente com alumina e produzidos pela técnica da colagem de barbotina e sinterizados a temperaturas próximas a $1450^{\circ} \mathrm{C}$, para seleção de uma temperatura. O meio micro poroso foi caracterizado pela técnica de porosimetria por intrusão de mercúrio, apresentando tamanho médio de poro de $0,5 \mu \mathrm{m}$. Os tubos foram submetidos à impregnação com solução de citrato de zircônio (precursor) por capilaridade. Posteriormente, os tubos foram calcinados e tratados termicamente até 600 e $900^{\circ} \mathrm{C}$, com o objetivo de eliminar componentes orgânicos voláteis e transformar o precursor no óxido metálico. A impregnação foi realizada em diferentes proporções e os tubos microporosos foram testados na bancada de micro-filtração, onde foram variados parâmetros fluidodinâmicos do processo (Reynolds e pressão transmembrana) e analisada as propriedades físico-químicas do volume de permeado, através de medidas da Concentração de Carbono Orgânico Total (TOC), condutividade elétrica, pH e a caracterização da mistura (concentrado) através de microscopia óptica. O meio micro poroso impregnado foi caracterizado por microscopia eletrônica de varredura (MEV), para analisar a morfologia do material impregnado e sua composição qualitativa. Os resultados do fluxo de permeado foram analisados e observou-se que os melhores resultados quanto ao fluxo transmembrana foram obtidos para o tubo impregnado a $900^{\circ} \mathrm{C}$. O tubo impregnado a $600^{\circ} \mathrm{C}$ apresentou melhor desempenho relativo à desemulsificação, por apresentar menores valores de TOC. Em relação ao processo de transferência de massa, o tubo impregnado $900^{\circ} \mathrm{C}$ obteve maiores valores de Sherwood, portanto a temperatura após impregnação influenciou no transporte de massa durante o processo de separação. A retenção da fase óleo analisada através de medidas de TOC foi de até $99 \%$.

Palavras-chave: Micro filtração; emulsões; tubos porosos; zircônia; transferência de massa. 
DEL COLLE, R. (2005). Demulsifying of stable emulsions of water and sunflower oil by cross-flow filtration process. M.Sc. Dissertation - School of Engineering of São Carlos, University of São Paulo, São Carlos, 2005.

The studied process used porous ceramic tubes manufactured predominantly with alumina and produced by the technique of the collage with barbotina and sintered to close temperatures for $1450^{\circ} \mathrm{C}$, for selection of a temperature. The microporous enviroment was characterized by mercury porosimetry, presenting medium size of pore of $0,5 \mu \mathrm{m}$. The tubes were submitted to the impregnation with solution of citrate of zirconium (precursory) by capillarity. Later on, the tubes were burned and thermally treated up to 600 and $900^{\circ} \mathrm{C}$, with the objective of to eliminate volatile organic components and to transform the precursory in the metallic oxide. The impregnation was accomplished in different proportions and the microporous tubes were tested in apparatus of microfiltration process, where were varied fluid dynamics parameters of the process (Reynolds and transmembrane pressure) and analyzed the physical-chemical properties of the volume of permeated, through measures of the Concentration of Total Organic Carbon (TOC), electric conductivity, $\mathrm{pH}$ and the characterization of the mixture (concentrated) through optical microscopy. The enviroment impregnated microporous was characterized by Scanning Eletronic Microscopy (SEM), to analyze the morphology of the impregnated material and its qualitative composition. The results of the flow of having permeated were analyzed and it was observed that the best results with relationship to the transmembrane flux were obtained for the tube impregnated for $900^{\circ} \mathrm{C}$. The tube impregnated for $600^{\circ} \mathrm{C}$ presented better relative acting to the demulsifying, for presenting smaller values of TOC. In relation to the process of mass transfer, the impregnated tube $900^{\circ} \mathrm{C}$ obtained larger values of Sherwood, therefore the temperature after impregnation influenced in the mass transport during the separation process. The retention of the phase oil analyzed through measures of TOC was of up to 99\%.

Keywords: Microfiltration, emulsions, porous tubes, zircônia, mass transfer. 
$C_{\mathrm{b}} \quad$ concentração do meio fluido (ppm)

$C_{0}$ concentração do meio fluido na entrada do tubo (ppm)

d diâmetro interno do tubo cerâmico (m)

D coeficiente de difusividade $\left(\mathrm{m}^{2} / \mathrm{s}\right)$

$J \quad$ fluxo transmembrana $\left(\mathrm{m} / \mathrm{s}\right.$ ou $\left.1 / \mathrm{h} \mathrm{m}^{2}\right)$

$k \quad$ coeficiente global de transferência de massa $(\mathrm{m} / \mathrm{s})$

L comprimento do módulo tubular (m)

$\Delta P_{t m}$ pressão transmembrana $\left(\mathrm{N} / \mathrm{m}^{2}\right.$ ou bar $)$

$Q \quad$ vazão $\left(\mathrm{m}^{3} / \mathrm{s}\right)$

$R \quad$ raio interno do tubo cerâmico (m)

Re adimensional de Reynolds: $R e=\rho . V . d / \mu$

Sc adimensional de Schmidt: $S c=\mu / \rho . D$

Sh......adimensional de Sherwood: $S h=k d / D$

$t \quad$ tempo (min)

$u \quad$ velocidade média $(\mathrm{m} / \mathrm{s})$

Letras gregas

$\mu \quad$ viscosidade $\left(\mathrm{N} \mathrm{s} / \mathrm{m}^{2}\right.$ ou centipoise)

$\rho \quad$ densidade $\left(\mathrm{kg} / \mathrm{m}^{3}\right)$ 
Figura 1. (a) Camada polarizada na superfície da membrana. (b) Princípio da micro filtração tangencial (Ripperger e Altman,2002). 20

Figura 2. Representação esquemática da reversão de fluxo (Sondhi et al, 2003). 30

Figura 3. Mudanças durante o estágio inicial de sinterização. (a) início, (b) rearranjo, (c) formação do pescoço. (Richerson,1992)

Figura 4. Mudanças ocorridas no segundo estágio. (a) crescimento do pescoço e retração no volume, (b) crescimento do pescoço e aumento do comprimento do contorno de grão, (c) crescimento de grão. (Richerson,1992) 31

Figura 5. Mudanças no estágio final de sinterização. (a) crescimento de grãos e descontinuidade da fase dos poros, (b) crescimento de grão e redução da porosidade, (c) crescimento de grão com eliminação da porosidade. (Richerson,1992). 32

Figura 6. Princípio da rejeição da gotícula de óleo por pressão capilar na superfície da membrana adaptada de:TING e WU, 1999. 39

Figura 7. Reação química para produção do citrato metálico. 45

Figura 8. Bancada experimental. (1) - tanque de armazenagem da mistura; (2) - bomba de escoamento; (3) - rotâmetro; (4) - módulo com membrana; (5) - sistema de controle de aceleração da bomba e controle de temperatura; (6) - tanque de armazenagem de água fria ou quente.

Figura 9. Análise de porosimetia por intrusão de mercúrio dos tubos cerâmicos sinterizados a diferentes temperaturas.

Figura 10. Fluxo trans-membrana em função do tempo, para os tubos impregnados queimados até $600^{\circ} \mathrm{C}$ e tubo sem impregnação. Reynolds: $R e \sim 20000$ (a); Re $\sim 16000$ (b); Re 12000 (c).

Figura 11. Fluxo trans-membrana em função do tempo para tubo impregnado uma vez a $900^{\circ} \mathrm{C}$ (a); tubo impregnado com solução $(2,07 \%)$ a 600 e $900^{\circ} \mathrm{C}($ b) .......58

Figura 12. Fluxo trans-membrana em função do tempo para um processo estático: tubos impregnados 2 vezes até 600 e $900^{\circ} \mathrm{C}$ (a); tubos impregnados 1 vez até 600 e $900^{\circ} \mathrm{C}(\mathrm{b})$. 
Figura 13. Gráfico dos valores adimensionais " $J / u$ " em função de " $\Delta \mathrm{P}_{\mathrm{tm}} / \rho . \mathrm{u}^{2}$ " para tubos com tamanho de poro de $0,5 \mu \mathrm{m}$, impregnados uma e duas vezes, queimados até $600^{\circ} \mathrm{C}$ e tubo sem impregnação para: Reynolds de 20335 a 22600 (a); Reynolds de 15609 a 16970 (b); Reynolds de 12602 a 13318 (c).

Figura 14. Gráfico entre os parâmetros adimensionais " $J / u$ " em função de " $\Delta \mathrm{P}_{\mathrm{tm}} / \rho . \mathrm{u}^{2}$ " para tubos cerâmicos com tamanho de poro de $0,5 \mu \mathrm{m}$, impregnados em concentrações diferentes, queimados até $600^{\circ} \mathrm{C}$ e $900^{\circ} \mathrm{C}$ e tubo sem impregnação para: Reynolds de 20335 a 22600 (a); Reynolds de 15609 a 16970 (b); Reynolds de 12602 a 13318 (c).

Figura 15. Resultados adimensionais do processo dinâmico. Tubo cerâmico com tamanho de poro de $0,5 \mu \mathrm{m}$, impregnado com solução mais concentrada, com temperatura de calcinação até $600^{\circ} \mathrm{C}$ e $900^{\circ} \mathrm{C}$.

Figura 16. Tubos cerâmicos com tamanho de poro de $0,5 \mu \mathrm{m}$, impregnados em concentrações diferentes com temperatura de calcinação até $600^{\circ} \mathrm{C}$ e $900^{\circ} \mathrm{C}$. Parâmetros adimensionais em processo estacionário.

Figura 17. Tubo impregnado uma vez a $600^{\circ} \mathrm{C}$. Para $R e=22600,16970,13318$. Valores de Sherwood para: (a) $\mathrm{t}=0 \mathrm{at}=15 \mathrm{~min}$; (b) $\mathrm{t}=15 \mathrm{at}=30 \mathrm{~min}$; (c) $\mathrm{t}$ $=30$ a $\mathrm{t}=45 \mathrm{~min}$. Comparação do adimensional de Sherwood (Sh) com a correlação de Deissler (ZEMAN e ZYDNEY, 1996). .68

Figura 18. Tubo impregnado duas vez a $600^{\circ} \mathrm{C}$. Para $R e=20335,16397,13103$. Valores de Sherwood para: (a) $\mathrm{t}=0 \mathrm{at}=15 \mathrm{~min}$; (b) $\mathrm{t}=15 \mathrm{at}=30 \mathrm{~min}$. Adimensional de Sherwood.

Figura 19. Tubo impregnado uma vez a $900^{\circ} \mathrm{C}$. Para $R e=20431,16119,12655$. Valores de Sherwood para: (a) $\mathrm{t}=0 \mathrm{at}=15 \mathrm{~min}$; (b) $\mathrm{t}=15$ a $\mathrm{t}=30 \mathrm{~min}$; (c) $\mathrm{t}$ $=30 \mathrm{at}=45 \mathrm{~min}$. Adimensional de Sherwood. .70

Figura 20. Tubo não impregnado. Para $R e=22483,15609,12602$. Valores de Sherwood para: (a) $\mathrm{t}=0 \mathrm{at}=15 \min$; (b) $\mathrm{t}=15 \mathrm{at}=30 \mathrm{~min}$; (c) $\mathrm{t}=30 \mathrm{at}=$ 45 min. Adimensional de Sherwood. 
Figura 21. Análise do permeado. TOC (mg/l) em função da pressão trans-membrana (bar) para Reynolds: próximo de 20000 (a); próximo de 16000 (b); próximo de 12000 (c).

Figura 22. Análise do permeado. TOC (mg/l) em função da pressão trans-membrana (bar) para processo estático (a); dinâmico (b). .76

Figura 23. Fluxo trans-membrana nas pressões trans-membrana: 2, 3, 4 e 5 bar para Reynolds próximo de 20000.

Figura 24. Valores de pH em função do tempo do processo, em diferentes Reynolds e pressões trans-membrana (2, 3, 4 e 5 bar). Para tubo impregnado 1 vez a $600^{\circ} \mathrm{C}$ (a); tubo impregnado 2 vezes a $600^{\circ} \mathrm{C}$ (b); tubo sem impregnação (c).

Figura 25. Condutividade elétrica em função do tempo do processo em diferentes pressões trans-membrana (2, 3, 4 e 5 bar) e para Reynolds acima de 20000 (a); acima de 16000 (b); acima de 12000 (c). Processo dinâmico. 80

Figura 26. Análise morfológica do material cerâmico tubular impregnado: tubo impregnado 1 vez (a) e respectivo mapeamento (b); tubo impregnado 2 vezes (c) e respectivo mapeamento $(d)$ 82

Figura 27. Análise morfológica do material cerâmico tubular impregnado. (a) tubo impregnado $1 \mathrm{vez} \mathrm{a} 900^{\circ} \mathrm{C}$ e respectivo mapeamento (b). 83

Figura 28. Representação de uma partícula e um aglomerado de partículas que podem se formar na estrutura micro porosa tubular.

Figura 29. Espectros dos raios- $x$ realizados através do microscópio eletrônico de varredura. (a) espectro respectivo à fig. 4.17 (a); (b) espectro respectivo à fig. 4.17 (b) no ponto 1; (c) espectro respectivo à fig. 4.17 (b) no ponto 2 .85

Figura 30. Difratogramas de raios-X para amostras de zircônia provenientes da solução precursora calcinada e tratada termicamente em temperaturas de 600 e $900^{\circ} \mathrm{C}$. 86

Figura 31. Imagens da emulsão (concentrado) tiradas através de microscópio óptico com aumento de 150x (a) e 75x (b). 
Figura 32. Distribuição do tamanho das gotículas de óleo presentes na mistura água/óleo (1\%). 88

Figura 33. Imagens captadas com câmera CCD para medição do ângulo de contato, entre o líquido e o material impregnado: água e tubo impregnado 1 vez a $600^{\circ} \mathrm{C}$ (a); óleo e tubo impregnado 1 vez a $600^{\circ} \mathrm{C}$ (b); emulsão e tubo impregnado 1 vez a $600^{\circ} \mathrm{C}$ (c). 89

Figura 34. Imagens captadas com câmera CCD para medição do ângulo de contato, entre o líquido e o material impregnado: água e tubo impregnado 1 vez a $900^{\circ} \mathrm{C}$ (a); óleo e tubo impregnado 1 vez a $900^{\circ} \mathrm{C}$ (b); emulsão e tubo

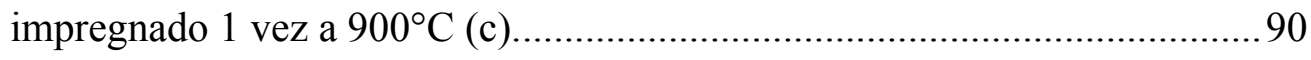

Figura 35. Imagens captadas com câmera CCD para medição do ângulo de contato, entre o líquido e o material não impregnado: água e tubo não impregnado (a); óleo e tubo não impregnado (b); emulsão e tubo impregnado (c)..................91 


\section{SUMÁRIO}

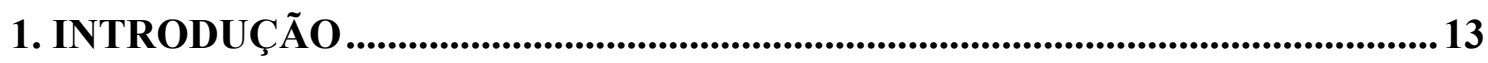

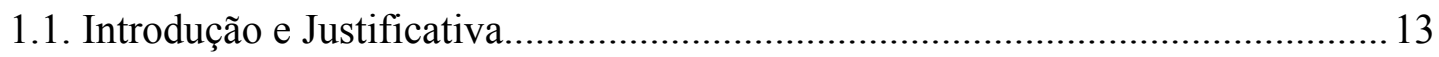

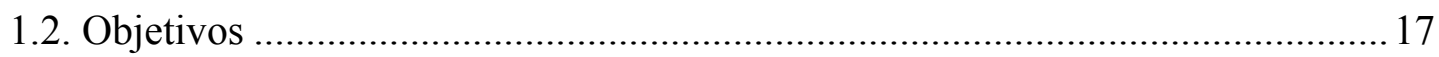

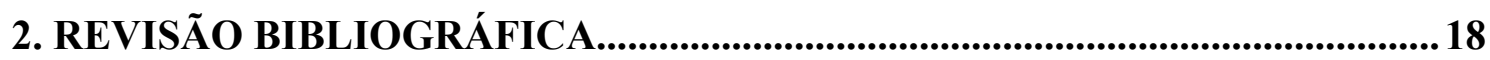

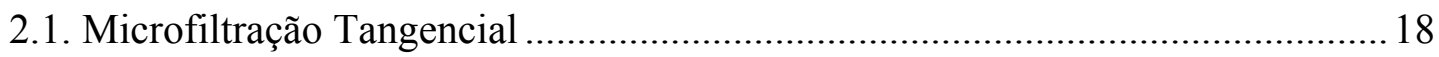

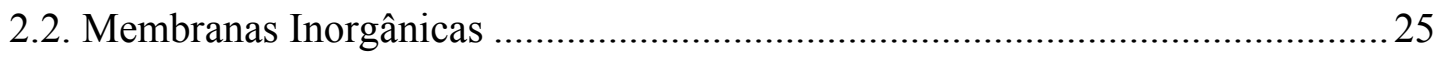

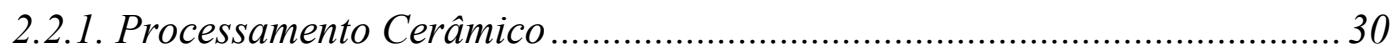

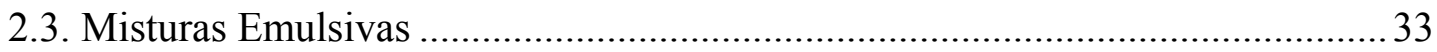

2.3.1. Macro e Micro Emulsões - Teoria e Aplicação .......................................... 33

2.3.2. Aspectos Físico-Químicos de uma Emulsão e sua Interação com

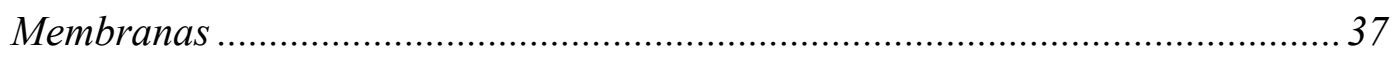

2.3.3. Tratamento de Resíduos Industriais ...................................................... 40

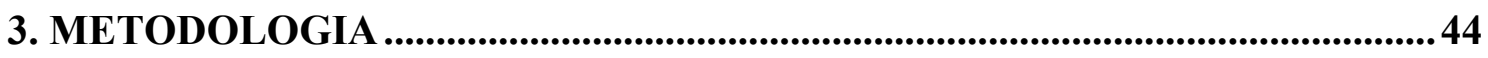

3.1. Preparação do Meio Micro Poroso ..................................................................... 44

3.1.1. Sinterização do material cerâmico tubular ................................................ 44

3.1.2. Obtenção do precursor da zircônia (solução de citrato de zircônio) .......... 44

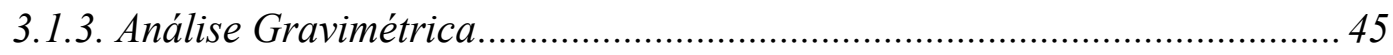

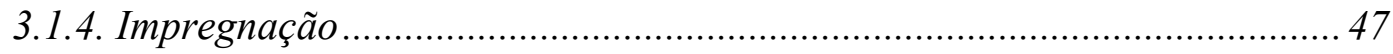

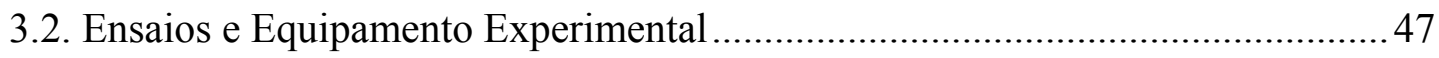

3.3. Análise Físico-Química do Permeado ..............................................................50

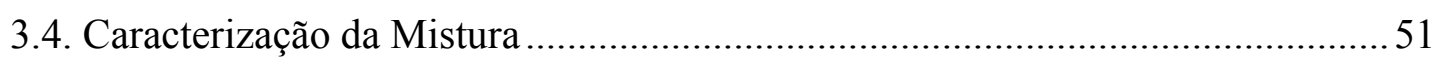

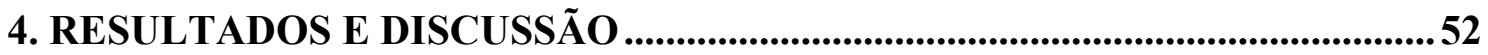

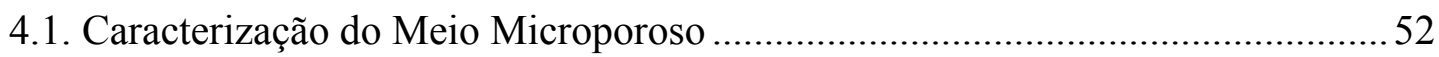

4.2. Análise dos Resultados do Processo de Micro Filtração......................................55

4.3. Caracterização da Micro Estrutura Cerâmica Impregnada.................................... 80

4.4. Caracterização da Mistura e sua Interação com o Meio Filtrante ......................... 86

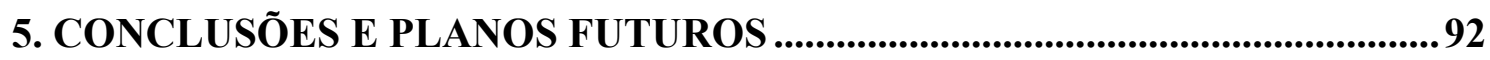

6. REFERÊNCIAS BIBLIOGRÁFICAS ............................................................95 


\section{INTRODUÇÃO}

\subsection{Introdução e Justificativa}

Atualmente é grande o número de pesquisas sobre os processos de micro e ultrafiltração. Este processo atuante em várias áreas da engenharia possui grande potencial para remoção de componentes em misturas sólido-líquido, líquido-líquido e gás-sólido. O processo também chamado filtração tangencial requer a circulação do fluido por uma superfície permeável confinada (membrana seletiva) sendo a mistura sujeita a diferenças de pressões trans-membrana entre 1 e 8 bar.

Esta espécie de filtração é classificada de acordo com o tamanho das partículas a serem separadas, tratando-se de uma separação de natureza física, sem a necessidade de uso de substâncias químicas, que podem poluir o meio ambiente. A tecnologia com membrana é vantajosa quando comparada ao processo convencional de extração de água, em que é necessária a mudança de estado do solvente durante o processo. Evaporação e congelamento são técnicas comuns de extração de água de produtos líquidos. O processo com membrana torna-se mais viável economicamente, pois não necessita da mudança de estado para ocorrer separação.

A maior vantagem deste tipo de filtração é a boa adaptação a materiais sensíveis a temperatura e ausência de compostos químicos como os processos de destilação e precipitação. A filtração por membrana oferece simplicidade e baixo custo de operação em comparação com a separação por centrifugação, filtração a vácuo e secagem por vaporização (spray drying). A microfiltração é também utilizada na produção de sucos e acúcares em seu processo de concentração, sendo economicamente vantajosa por consumir menor energia em relação ao equipamento tradicional de evaporação (QUEIROZ, 2004). 
Neste tipo de processo, não é necessário equipamentos de manutenção complexos que envolvem transferência de calor, mas apenas a operação da membrana que requer energia elétrica para funcionamento da bomba hidráulica e, podendo estar situada longe da planta de geração de energia primária. Não é necessário condensadores, evitando problemas como poluição térmica e sobrecarga do sistema de tratamento de efluentes.

O processo de filtração tangencial apresenta vantagens significativas como: i) a mesma tecnologia pode ser aplicada em diversos setores da indústria; ii) a precisão na seletividade da membrana é alta, e a qualidade do permeado tem pouca variação; iii) a técnica minimiza o uso de agentes químicos; iv) concentrados de macromoléculas e óleos são alcançados acima de $70 \%$; v) a instalação é compacta e requer menor consumo de energia do que processos térmicos; vi) a planta pode ser automatizada requerendo baixa manutenção.

O conhecimento do processo de separação água-óleo é de grande importância na indústria petroquímica, química e de alimentos, especialmente na solução de problemas relativos à proteção do ambiente aquático. Desta forma, a tecnologia com membranas tem sido intensamente investigada como técnica alternativa para a separação de emulsões estáveis de hidrocarbonetos (SRIJAROONRAT, JULIEN e AURELLE, 1999), contribuindo no processo de remoção de óleos em misturas com água (XU et al, 1999).

A literatura apresenta muitas investigações a respeito do tratamento de emulsões utilizando a filtração tangencial (LOPEZ et al, 19995 e NAZZAL e WIESNER, 1996). Koltuniewicz e Field (1996) estudaram experimentalmente a separação de óleo de águas através do uso de membranas. Variando parâmetros que influenciam diretamente o processo, tais como, pressão trans-membrana, regime de escoamento, concentração de óleo e temperatura. Foram comparados os desempenhos de membranas poliméricas e cerâmicas, através da análise das curvas de fluxo trans-membrana com o tempo. As membranas cerâmicas demonstraram melhor desempenho, com pouca queda do fluxo trans-membrana e inibição do efeito de polarização.

Hyun e Kim, 1997 apresentam um estudo a respeito do desempenho de membranas cerâmicas sintetizadas especialmente para o tratamento de emulsões originárias da indústria petroquímica. As membranas de alumina e zircônia foram 
caracterizadas a partir do processo de separação de misturas preparadas com água deionizada e querosene.

Nesse estudo a distribuição do tamanho de gotas de óleo foi medida utilizando um analisador de partículas. O processo foi mantido para pressões trans-membrana no intervalo de 1 a 3 bar e velocidade média no tubo poroso no valor de $0,27 \mathrm{~m} / \mathrm{s}$, em condições típicas de microfiltração. A eficiência de separação foi verificada através da análise química de carbono total no permeado. O coeficiente de rejeição alcançou $98 \%$ usando membranas de $0,16 \mu \mathrm{m}$ (tamanho médio dos poros), com vazões de permeado da ordem de $2501 / \mathrm{h} \mathrm{m}^{2}$.

Para emulsões estáveis típicas da indústria alimentícia (oliva/água) a ultrafiltração também tem sido uma opção vantajosa, pois reduz o uso de estabilizantes químicos típicos de processos convencionais (NABI et al, 2000). O uso de membranas cerâmicas também foi satisfatório na produção de caseína (VIOTTO e RIZVI, 1998).

Venturini, Dornier e Belleville (2000) estudaram a otimização da microfiltração no processo de concentração do suco de laranja. Outras investigações são desenvolvidas pelo primeiro autor envolvendo a clarificação no processamento de bebidas licorosas.

Pesquisas com membranas cerâmicas foram inicialmente direcionadas na preparação de membranas de alumina, estas foram amplamente aplicadas, mas atualmente, vários outros materiais tais como: zircônia, titânia e sílica estão sendo considerados. Dentre esses, zircônia é o material mais interessante para membranas inorgânicas. As qualidades excepcionais de membranas de zircônia são: alta resistência química que permite esterilização a vapor e procedimentos de limpeza em ampla faixa de $\mathrm{pH}(0-14)$, boa permeabilidade em água pura e alto fluxo na separação e filtração devido às propriedades de superfície específicas da membrana e alta estabilidade térmica, que é muito atrativa no caso de membranas usadas em reatores de catálise a altas temperaturas.

Emulsões água-óleo emitidas de indústrias siderúrgicas são um dos maiores poluentes do ambiente aquático. Ultra ou microfiltração com membranas cerâmicas é um dos métodos de separação mais eficazes em comparação com métodos de separação tradicionais, neste caso. Alguns estudos com membranas de zircônia mostraram vantagens no desempenho da separação quando comparadas com outras membranas, tal como: alto fluxo, menor obstrução dos poros, alta rejeição do óleo (YANG et al, 1998). 
O comportamento de membranas alumina-zircônia é provavelmente atribuído as diferentes propriedades superficiais do material, tal como tensão superficial, carga de superfície e sorção de íons em solução aquosa.

O óleo de girassol vem ganhando um crescente espaço no comércio nacional e internacional devido à excelente qualidade do óleo comestível extraído de sua semente. A qualidade e digestibilidade dos óleos comestíveis são determinadas pela quantidade e qualidade dos ácidos graxos insaturados que os compõem. É fundamental a presença do ácido linoléico em quantidades adequadas, já que o organismo humano não consegue sintetizá-lo, o óleo de girassol é considerado o de melhores características nutritivas pelo alto teor de ácido linoléico (ácido graxo insaturado). O acúmulo de ácidos graxos saturados no organismo humano está diretamente ligado ao aumento de colesterol, responsável por doenças cardiovasculares.

Reduzindo a quantidade de saturados em relação aos insaturados, espera-se que haja redução dessas doenças. Em vista disso, o óleo de girassol torna-se excelente para consumo. O óleo de girassol apresenta ainda grande vantagem, pôr sua capacidade de conservação por períodos prolongados, devido ao baixíssimo conteúdo de ácido oléico (Aboissa - Óleos Vegetais). O óleo de girassol refinado é também utilizado pela indústria de conservas. As margarinas e os cremes vegetais são cada vez mais consumidos. Com o aumento na produção da indústria que processa óleos comestíveis, o problema da geração residual de emulsões também deve ser considerado. Também é usado na fabricação de sabões, como óleo industrial e na indústria de tintas e recentemente vem sendo usado como combustível alternativo (biodiesel) devido as suas inúmeras vantagens ambientais, sociais e econômicas.

Sendo que o maior benefício proporcionado por esse combustível alternativo é ambiental, pois sua emissão de dióxido de carbono é 78\% inferior à do óleo diesel. Desse modo, haverá uma contribuição para a redução dos gases que provocam o efeito estufa, que aumenta a temperatura da Terra. 


\subsection{Objetivos}

O objetivo geral desta dissertação é a investigação experimental do processo de filtração tangencial aplicado na desemulsificação de misturas estáveis de água e óleo vegetal (girassol). No processo foram utilizados como meio filtrante, tubos porosos de alumina, sujeitos também ao tratamento químico através da impregnação de zircônia. Os objetivos específicos são:

- Impregnação do óxido metálico (zircônia) em concentrações diferentes no meio filtrante (tubos cerâmicos micro porosos de alumina).

- Estudar o desempenho do processo de filtração tangencial para a desemulsificação de emulsões utilizando-se tubos micro porosos com e sem impregnação de zircônia.

- Caracterização do meio filtrante e do processo quanto aos mecanismos de transferência de massa, através da investigação com medidas de propriedades físicoquímicas do permeado e com variação de parâmetros fluidodinâmicos: número de Reynolds e pressão trans-membrana. 


\section{REVISÃO BIBLIOGRÁFICA}

\subsection{Microfiltração Tangencial}

Várias técnicas como a nanofiltração, ultrafiltração, microfiltração e osmose reversa por membrana, podem ser usadas para separação de misturas (sólido/sólido ou líquido/líquido). A distinção entre elas se faz pela pressão a ser aplicada no processo e o tamanho da partícula. A seletividade quanto ao tamanho das partículas a serem separadas indica qual a melhor técnica a ser usada. A natureza físico-química da própria membrana controla quais componentes da mistura serão filtrados e quais serão retidos.

A microfiltração tem sido usada desde o início do século 20, com a preparação de membranas micro porosas sintéticas baseadas na celulose. Nos últimos 30 anos o processo de micro filtração vem sendo utilizado em vários processos industriais, atualmente a sua aplicabilidade tem aumentado em várias áreas como, no tratamento de água para consumo humano.

Micro filtração é um processo de separação que utiliza um gradiente de pressão como força motriz, separando partículas com tamanho de 0,06 a $10 \mu \mathrm{m}$, através de membranas micro porosas. Portanto, a micro filtração está classificada entre a ultrafiltração e a filtração convencional. A separação de partículas de materiais distintos ocorre espontaneamente em função de seus tamanhos, independente da temperatura e da densidade do material a se separar. Esse processo de separação se baseia no efeito peneira molecular e macromolecular, que é limitado pela superfície da membrana. Existem dois tipos de micro filtração que são empregados: o método perpendicular e o tangencial.

$\mathrm{Na}$ micro filtração perpendicular ou convencional, o fluxo de alimentação se estabelece perpendicularmente à superfície da membrana, e as partículas se concentram 
na superfície e/ou nos poros da membrana, formando uma camada de filtrado sólido que com o tempo pode aumentar e consequentemente diminuir a eficiência da filtração. Um aumento da pressão pode melhorar o processo por pouco tempo, porém, quando os poros são obstruídos, o fluxo é interrompido e a membrana tem que ser trocada, tornando o método pouco viável economicamente. Este tipo de incrustação pode ser controlada e reduzida com a micro filtração tangencial (SCOTT, 1995).

Tal incrustação pode ocorrer nos dois métodos, no entanto ocorre mais facilmente na micro filtração convencional, pois o fluxo chega diretamente na membrana, assim, este método é recomendado para líquido pouco concentrado em sólido; diferentemente da micro filtração tangencial utilizada para líquido contendo alta concentração de sólidos.

A corrente de alimentação é mantida sem interrupção através de uma membrana no processo de micro filtração tangencial, com velocidade e pressão específicas, de acordo com as necessidades de cada experimento. Uma velocidade de alimentação baixa evita a rápida formação da camada de polarização, proporcionando um controle da incrustação do módulo.

$\mathrm{Na}$ micro filtração tangencial, o fluido pode ser filtrado mantendo-se o fluxo paralelo à superfície da membrana e consequentemente o fluxo de permeado pela mesma, também devido à diferença de pressão. O fluxo tangencial em intervalos adequados ao regime de escoamento, pode reduzir a formação da camada de polarização no meio filtrante, possibilitando um fluxo de filtrado quase constante por muito tempo.

Quando uma corrente tangencial é filtrada, ocorre-se a formação de uma camada de polarização na membrana (figura1.(a)), que é causada pela constrição do tamanho do poro, bloqueio do poro, ou deposição de células, restos de células ou outras partículas da mistura, tais como macromoléculas no topo da superfície da membrana, fazendo-se com que a vazão do permeado diminua (CZEKAJ, LÒPEZ e GÜELL, 2001).

Os processos da filtração tangencial são principalmente determinados pela formação desta camada de polarização na membrana. Um melhor conhecimento da formação da camada e da deposição de partículas na membrana poderiam resultar em um uso mais econômico da filtração tangencial em muitas aplicações técnicas (RIPPERGER e ALTMANN, 2002). 


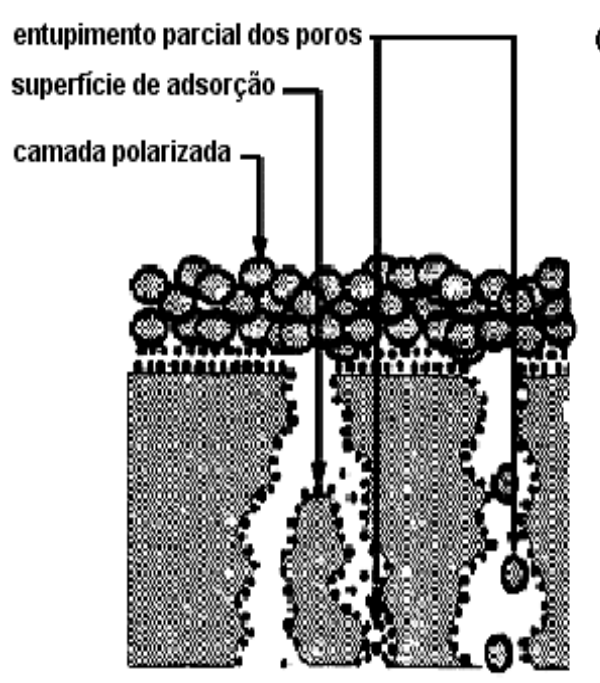

(a)

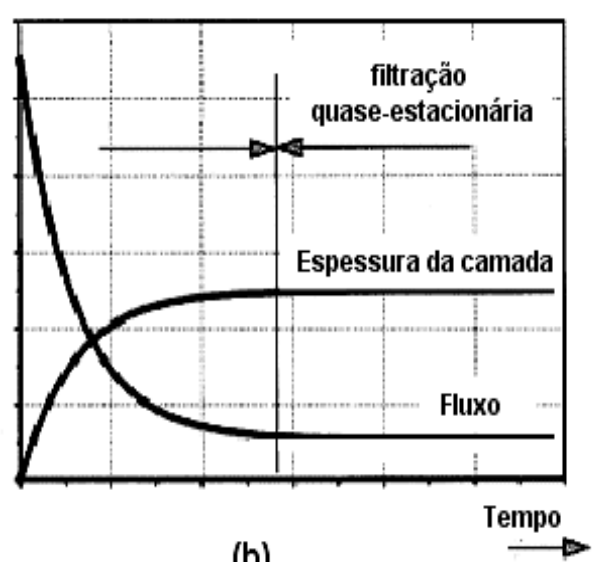

(b)

Figura 1. (a) Camada polarizada na superfície da membrana. (b) Princípio da micro filtração tangencial (Ripperger e Altman,2002).

Em micro filtração, os colóides (bactérias e suspensões macromoleculares) podem aderir à superfície da membrana ou poros, dependendo do tamanho e da forma do colóide. A retenção das partículas junto à superfície da membrana é devido ao fenômeno da camada de polarização. Este fenômeno é manifestado devido à diminuição da vazão de permeado e alteração nas propriedades seletivas da membrana, e tem sua origem devido às interações físico-químicas da mistura com a membrana.

Partículas muitas menores que os poros da membrana podem ser depositadas internamente, as quais podem bloqueá-los, e partículas muito maiores serão depositadas na superfície da membrana formando uma camada de resistência conforme mostra a figura 1.(a).

Por outro lado, outro efeito de entupimento chamado fouling provoca alteração irreversível devido a interações físicas e/ou químicas específicas entre a membrana e os vários componentes presentes na mistura. A vazão de filtrado e soluto passam a ter variações semelhantes àquelas associadas com o fenômeno de polarização. No entanto, a polarização é um fenômeno reversível em nível de camada limite podendo ser controlada, por exemplo, com condições de operação de fluxo reverso.

Um dos maiores problemas relacionados ao entendimento do mecanismo da formação do fouling, é distinguí-lo entre os efeitos de polarização. Muitos 
pesquisadores têm atribuído o rápido declínio da vazão como o começo do processo de polarização.

Certos parâmetros neste processo, tais como: velocidade tangencial, pressão e temperatura, podem influenciar no comportamento do fouling. De todos esses fatores três categorias gerais devem ser examinadas: propriedades do material da membrana, propriedades do soluto e parâmetros de operação, cada um destes podem interagir entre si e complementar significativamente efeitos diferentes em combinação do que se esses efeitos fossem estudados separadamente ou com modelos de sistemas.

Uma conseqüência evidente do fouling é o alto custo de manutenção e limpeza da membrana causada pelo pequeno fluxo médio. Como resultado, dependendo da natureza e extensão do fouling, a restauração do fluxo pode requerer agentes potentes de limpeza, que podem reduzir a vida útil da membrana. Para membranas de acetato de celulose que tem um limite de $\mathrm{pH}$, temperatura e taxa de tolerância de cloro, isso pode se tornar um problema, ao contrário de outras membranas poliméricas e outras membranas inorgânicas que podem tolerar procedimentos de limpeza agressivos. Rejeição e rendimento podem ser afetados. Se a armazenagem de sólidos na membrana é significante o bastante, ela pode agir como membrana secundária e mudar a eficiência da separação e propriedades de transporte do sistema.

Partículas muito menores que os poros da membrana poderão se depositar no interior deles conforme a figura 1(a), conduzindo ao fechamento do poro. Partículas de tamanho semelhante ao poro bloquearão o mesmo e partículas maiores causarão a formação de uma camada, com a porosidade dependendo do tamanho da partícula (QUEIROZ, 2004).

De acordo com Belfort, Davis e Zydney (1994), incrustações coloidais ocorrem em dois estágios: incrustações internas e externas. A incrustação interna é causada pela adsorção ou deposição de partículas pequenas e macromoléculas dentro da estrutura interna dos poros.

Para descrever a incrustação interna dois modelos foram propostos: modelo padrão de bloqueio (Standard Blocking Model-SBM), que assume que as moléculas são adsorvidas nas paredes do poro, reduzindo seu diâmetro efetivo; e o modelo de bloqueio do poro (Pore Blocking Model-PBM), este modelo assume que as moléculas ou agregados bloqueiam completamente alguns dos poros deixando outros inalterados. Os dois fenômenos podem ocorrer durante a filtração. A incrustação externa é descrita pelo 
Modelo de filtração de camada (Cake Filtration Model-CFM) que assume que o agente filtrado (célula, restos de células e agregados) forma uma camada na superfície da membrana e a resistência cresce gradualmente.

Existe uma enorme variedade de espécies inorgânicas que podem causar um significante fouling em membranas durante a micro filtração. Muitos destes compostos inorgânicos estão presentes nos alimentos e nas águas de superfície. Eles incluem sulfato de cálcio, carbonato de cálcio, sílica, óxidos metálicos e hidróxidos (principalmente de ferro e alumínio), colóides de enxofre, e outros particulados inorgânicos. $\mathrm{O}$ entupimento causado por compostos de metais e sais, geralmente ocorre por precipitação ou floculação dentro dos poros da membrana. Em vários processos, sais de cálcio são um dos mais importantes agentes de indução ao entupimento fouling, como por exemplo, na indústria de processamento de queijo (ZEMAN e ZYDNEY, 1996).

No trabalho de Yang et al. (1998), um fluxo mais alto e estável foi observado para membrana compósita de zircônia para processo de micro filtração, na qual houve um fouling num grau insignificante, em comparação com três membranas (com diferentes porosimetrias) alumina, devido a um evidente entupimento causado pelo óleo. Pôde-se concluir que a membrana zircônia com diâmetro de poro de $0,2 \mu \mathrm{m}$, foi a membrana escolhida para tratamento de emulsão água-óleo devido ao seu melhor desempenho.

O processo de micro filtração tangencial pode ser:

-Descontínuo (ou batelada):

O produto a ser filtrado é recirculado tanto quanto necessário até se obter a concentração desejada de sólido no tanque de alimentação ou até que o mesmo atinja os limites de fluidez. Nesse momento diminui a eficiência da filtração e o processo é interrompido.

\section{-Contínuo:}

Parte do volume do concentrado é retirado continuamente de circulação. $\mathrm{O}$ volume equivalente à soma do volume concentrado retirado e do volume filtrado, obtido até aquele instante em que é introduzido no tanque de alimentação.

A micro filtração tangencial pode ser processada de dois modos: mantendo-se a pressão constante através do meio filtrante, com conseqüente perda de vazão ou 
aumentando-se a pressão para manter a vazão. Por medida de segurança o primeiro modo é usado.

Estes fenômenos hidrodinâmicos podem ser quantificados por diferentes parâmetros, como, tensão de cisalhamento ou taxa de deformação na parede da membrana, velocidade tangencial, pressão trans-membrana, resistência da membrana e da camada de polarização, número de Reynolds e efeitos de superfície da partícula. Dentre estes parâmetros, o mais utilizado é a velocidade tangencial, principalmente quando a influência qualitativa do fluxo tangencial no permeado é estudada, mas qualquer parâmetro pode ser utilizado quando correlações são desenvolvidas para representar este fluxo.

Os modelos que descrevem a micro filtração tangencial são: modelos empíricos e físicos. Modelos físicos são focalizados, porque considerações empíricas são úteis na prática, mas não são muito significativas para o entendimento do processo físico de filtração tangencial. A divisão dos modelos físicos em macroscópico e microscópico é prática, porque a aproximação macroscópica considera o sistema particulado como um todo, já o microscópico considera o comportamento de uma única partícula durante a filtração. Essas aproximações reduzem um grande número de influência de parâmetros para três mecanismos físicos:

- hidrodinâmica das partículas

- difusão das partículas

- interações da partícula e efeitos de superfície.

$\mathrm{Na}$ década de setenta, os primeiros modelos macroscópicos da filtração tangencial, basearam-se na difusão e concentração de polarização de membrana. Estes modelos consideram os parâmetros que afetam o fluxo no caso de sólidos suspensos com modelos matemáticos baseados na difusão. O movimento de difusividade das partículas causa um transporte oposto ao transporte convectivo do filtrado. No estado estacionário, ambos os mecanismos de transporte estão em equilíbrio. A taxa de filtração pode ser calculada pela equação 1 (ZEMAN \& ZYDNEY, 1996) da seguinte forma:

$$
v_{F}=\frac{D}{\delta} \ln \left(\frac{C_{M-} C_{P}}{C_{F-} C_{P}}\right)=k \ln \left(\frac{C_{M-} C_{P}}{C_{F-} C_{P}}\right)
$$


O coeficiente de transferência de massa k é a relação do coeficiente de difusão D e a espessura da camada limite de concentração $\delta$. A concentração do componente a ser separado no líquido permeável $\mathrm{C}_{\mathrm{P}}$, é determinado pelas características da membrana. $\mathrm{O}$ $\mathrm{C}_{\mathrm{F}}$ é a concentração da alimentação. A concentração na superfície da membrana $\mathrm{C}_{\mathrm{M}}$, é a concentração máxima de um sistema de partícula de fluxo. Os modelos de difusão macroscópicos são freqüentemente um caso incerto de modelos semi-empíricos e empíricos, porque eles não consideram só efeitos de corrente térmica e difusão turbulenta. Este modelo inclui todos os efeitos da interação, hidrodinâmica e difusão das partículas, em um coeficiente de difusão D.

O ponto de partida de modelos microscópicos é a consideração das forças agindo numa única partícula. $\mathrm{Na}$ modelagem quatro agentes diferentes estão sendo desenvolvidos, tais agentes predizem o fluxo limite para a operação de micro filtração. O fluxo limite é a pressão independente do fluxo, obtida quando altas pressões transmembranas são aplicadas. Depende da velocidade tangencial, temperatura, propriedades de suspensão na alimentação e da geometria do módulo da membrana.

Levando em consideração a influência de forças de interação da partícula no processo de micro filtração tangencial, esta se torna significativa para determinar dois efeitos:

- influência no sistema de partículas pela ação da aglomeração ou floculação;

- influência no comportamento de deposição da partícula e ressurgimento de partículas vindas da camada.

A micro filtração tornou-se um processo estabelecido para a separação de micro partículas, bactérias e emulsões em uma variedade de aplicações industriais. Freqüentemente uma concentração muito alta de uma mistura fluida pode ser alcançada, por isso a micro filtração tangencial é normalmente utilizada em combinação com outros processos de separação (RIPPERGER e ALTMANN, 2002). Atualmente este modo de operação é padrão em várias aplicações nas áreas médicas e técnicas, conhecido também como filtração dinâmica. Também pode ser usada para a produção de líquidos puros, para a concentração de suspensões, recuperação de produtos e regeneração de processos líquidos.

A micro filtração tangencial é utilizada em diferentes tipos de indústrias, demonstrando uma extensa aplicação desta técnica de separação em: 
- Clarificação de suco de fruta, vinho, sidra e vinagre;

- Separação de gordura e remoção bacteriana do leite;

- Remoção do fermento de cerveja;

- Clarificação de soro antes de outra etapa de filtração por membrana, como ultrafiltração ou eletrodiálise;

- Tratamento da água potável sem adição de substâncias químicas (redução da carga microbiana);

- Filtração de caldos de fermentação;

- Tratamento de águas residuárias de processos metalúrgicos gerados de misturas água/óleo (QUEIROZ, 2004).

\subsection{Membranas Inorgânicas}

A membrana pode ser constituída por um polímero orgânico ou inorgânico, metal, cerâmica, camadas químicas ou mesmo líquidos ou gases. A aplicação de uma força direcionada (pressão, concentração, potencial elétrico, etc.) pressionam alguns elementos da solução pela membrana. A membrana controla a taxa relativa do transporte de várias espécies, e como toda separação, proporciona um produto com baixas concentrações de um determinado componente e um outro produto com altas concentrações do mesmo.

O desempenho da membrana é definido em termos de dois fatores simples, fluxo e retenção ou seletividade. Fluxo ou taxa de permeado é o fluxo volumétrico de fluido que passa através da membrana por unidade de área por tempo. Seletividade é uma medida da taxa relativa de permeado de vários componentes através da membrana.

Nos processos de micro filtração e ultrafiltração, o gradiente de pressão através da membrana deve conduzir o solvente e as pequenas espécies pelos seus poros, enquanto as moléculas mais largas devem ser retidas. Assim, uma vazão de alimentação é dividida em duas, a vazão do concentrado que será enriquecido de macromoléculas retidas e a vazão do permeado que será deficiente em macromoléculas.

A estrutura dos micro poros da membrana deveria ter uma pequena distribuição do tamanho dos poros para garantir a retenção quantitativa das partículas de um mesmo tamanho e tipo (RIPPERGER e ALTMANN, 2002). Outra característica importante é a 
alta permeabilidade da membrana que leva a altas taxas de filtração com pequenas diferenças de pressões.

As propriedades dos micro poros das membranas são determinadas através do processo e materiais usados. As membranas poliméricas são geralmente usadas nos procedimentos de filtração. Estes tipos de membrana são favoráveis em termos da relação custo/benefício. As membranas de micro filtração (MF) de materiais inorgânicos como a cerâmica, o metal e o carbono, são utilizadas quando é necessário, por exemplo, uma alta estabilidade térmica.

As membranas podem ser classificadas segundo as várias características da sua natureza:

a) Natural ou sintética;

b) Estrutura porosa ou não;

c) Ação de mecanismo: adsortiva ou difusiva, troca iônica, osmótica ou membranas não seletivas.

Dentre as membranas inorgânicas, destacam-se as cerâmicas por serem ótimos materiais para a produção dos tubos de filtração, pois permite alta velocidade de alimentação da filtração tangencial, resultando em um regime turbulento que previne a formação de incrustações e garante um fluxo altamente permeável.

Membranas minerais ou cerâmicas deveriam ser extremamente versáteis, visto que elas são feitas de materiais inorgânicos e, portanto deveriam ter poucas das desvantagens associadas com membranas poliméricas. Camadas de alumina sinterizada não serão retiradas sob condições de alta temperatura, pressão ou queda de fluxo. Porém, deve-se lembrar que, ainda que a própria membrana seja muito resistente a parâmetros de operação extremos, a presença de materiais orgânicos no módulo limita seu desempenho (CHERYAN, 1998).

Algumas vantagens das membranas cerâmicas em comparação com as poliméricas são:

- Resistência a temperaturas acima de $280^{\circ} \mathrm{C}$ (especialmente modelos desenvolvidos e sistemas acima de $700^{\circ} \mathrm{C}$ );

- Boa resistência à corrosão: resistente a solventes orgânicos e extensa faixa de $\mathrm{pH}$; 
- Membranas cerâmicas são apropriadas para limpeza e esterilização;

- Longa vida operacional;

- Quimicamente inerte: aplicações variadas na indústria.

As apresentadas acima mostram que este tipo de membrana tem diversas aplicações nos processos de separação, como, por exemplo, misturas de tinta/água, emulsões água/óleo, tratamento de esgoto, etc.

As desvantagens em relação às membranas poliméricas são:

- Devido sua fragilidade deve ser manuseada com cuidado;

- A taxa superficial área/volume é baixa, conduzindo a sistemas com maiores dimensões;

- Segundo Scott (1995), o investimento inicial em membranas de cerâmica é alto.

Membranas cerâmicas hoje movimentam uma gama variada em termos de materiais (de alfa alumina a zircônia), aplicações (de filtração de suco de maça a óxido de zinco) e benefícios. Porém, elas são relativamente discutidas, ainda são recente no mundo da filtração tangencial de líquidos. Então, novas aplicações e benefícios de forma crescente estão sendo encontrados para o uso dessas membranas.

Clarificação de sucos de fruta natural como maça e uvas são uma das mais amplas e bem sucedidas aplicações de membranas cerâmicas. Membranas cerâmicas de filtração fornecem uma alternativa particularmente atrativa, substituindo tratamentos convencionais. Membranas produzem clarificação superior de sucos e baixo custo comparado com processos de clarificação convencionais (SONDHI et al, 2003).

Na filtração do caldo da cana de açúcar, podem-se usar membranas cerâmicas em diversos estágios no produto bruto até no refino do açúcar. Uma oportunidade interessante do uso da micro/ultrafiltração está na clarificação do suco e/ou préevaporação do suco como um pré-tratamento para separações através de troca-iônica ou por cromatografia. A necessidade de compra, preparação e uso de filtros é eliminado, no caso da micro ou ultrafiltração, em algumas aplicações, o custo do equipamento necessário para desidratar os filtros pode ser comparado ao custo do sistema de membrana. 
Em muitas indústrias alimentícias e de bebidas, soluções cáusticas aquecidas são usadas para limpar uma variedade de equipamentos tais como: tanques, misturadores, evaporadores e cristalizadores. Isto é necessário para manter condições próprias de limpeza entre as produções em série. As soluções cáusticas consumidas contêm sólidos suspensos (polpas, proteínas de baixo peso molecular, polímeros orgânicos e oligossacarídeos), e aditivos tais como agentes umidecedores e surfactantes. Membranas cerâmicas são capazes de reter os sólidos suspensos e permitir a permeação dos aditivos.

Essas membranas são resistentes ao ataque biológico e esterilização à vapor, por isso que provavelmente há menor contaminação por bactérias. Tal aspecto é altamente atrativo para indústrias alimentícias e farmacêuticas. Ultrafiltração ou osmose reversa com membranas pode substituir processos convencionais de alimentos, como por exemplo, destilação, por isso minimiza a degradação térmica e reduz o consumo de energia (WU e LEE, 1999).

Óleo de soja é tipicamente extraído de tortas do grão por hexano, no processo do óleo comestível. O extrato bruto normalmente contém de $25-30 \%$ em peso de óleo de soja. O hexano que é removido por destilação consome a maior parte do custo de energia de uma planta típica para produção de óleo de soja. A praticabilidade do uso de processos com membranas para remover o solvente do óleo vegetal cru foi examinada por Köseoglu et al. (1990). Porém, as membranas poliméricas foram prejudicadas pelo hexano. Se o hexano é parcialmente separado por ultra filtração usando membranas cerâmicas, o consumo de vapor pode ser menor do que o processo de destilação elétrico.

Solventes orgânicos causaram danos em membranas de material polimérico, por mudar a estrutura dos poros. A instabilidade dessas membranas em solventes não aquosos representa uma de suas maiores desvantagens, ao contrário de membranas inorgânicas. Guizard et al. empregou membranas de alumina, zircônia e sílica na ultrafiltração para separação do asphaltene (ou betume - um dos produtos que forma a mistura de hidrocarbonetos mais pesados que ficam no fundo de uma torre de destilação fracionada do petróleo bruto) do óleo cru no intervalo de temperatura de $155-180^{\circ} \mathrm{C}$, e encontrou que membranas zircônia mostraram maior fluxo do que membranas alumina e sílica por causa do baixo nível de interação com asphaltene (TSURU et al, 2001).

Hyun e Kim (1997) testaram membranas sintéticas em sistema de micro filtração tangencial para separação do óleo de emulsões óleo em água, com pressão transmembrana de 0,98 a 2,94 bar, velocidade tangencial de 0,27 a $0,55 \mathrm{~m} / \mathrm{s}$, e concentração 
da emulsão de 600 a 11.000 ppm à temperatura ambiente. Eles observaram que variações para essas condições não causaram eficiência na separação do óleo. Testaram também o fluxo do permeado e a eficiência na separação do óleo para membranas compósitas de alumina e zircônia, ambas com parâmetros de operação iguais (pressão trans-membrana de 2,94 bar e velocidade tangencial de $0,27 \mathrm{~m} / \mathrm{s}$ à temperatura de $25^{\circ}$ C). Em ambos os casos, houve uma queda significativa no fluxo do permeado, mas mais abrupta para a membrana compósita de alumina (de 280 a $50 \mathrm{~L} / \mathrm{m}^{2} \cdot \mathrm{h}$ em 20 minutos de operação) devido a uma torta criada na superfície da membrana pelas gotículas de óleo acumuladas, que causaram uma barreira aumentando a resistência ao fluxo. Mas depois de certo tempo, o fluxo mostrou-se quase constante.

O fouling foi pouco pronunciado para a membrana compósita de zircônia, pois o diâmetro dos poros da mesma $(0,07 \mu \mathrm{m})$ era menor do que os da membrana compósita de alumina $(0,16 \mu \mathrm{m})$. Assim, as gotículas de óleo relativamente grandes causam um maior bloqueio nos poros da membrana compósita de alumina em relação à outra. As duas membranas apresentaram quase $100 \%$ de eficiência na remoção de óleo da emulsão o/a.

Membranas cerâmicas são ideais para limpeza com agentes químicos a altas temperaturas, de vez em quando usando soda cáustica, cloro, peróxido de hidrogênio, ozônio e ácidos inorgânicos fortes e/ou usando esterilização à vapor. Essas membranas também podem ser forçadas reversamente, que é basicamente uma técnica que inverte o fluxo do permeado para reduzir o fouling e aumentar a eficiência da filtração. Esta técnica é um método in situ para limpar a membrana por reverter periodicamente o fluxo do permeado através da pressão aplicada ao lado do permeado (SONDHI et al, 2003). Desta forma, o líquido do permeado é forçado a voltar através da membrana para o lado da mistura de alimentação, conforme mostra a figura 2. 


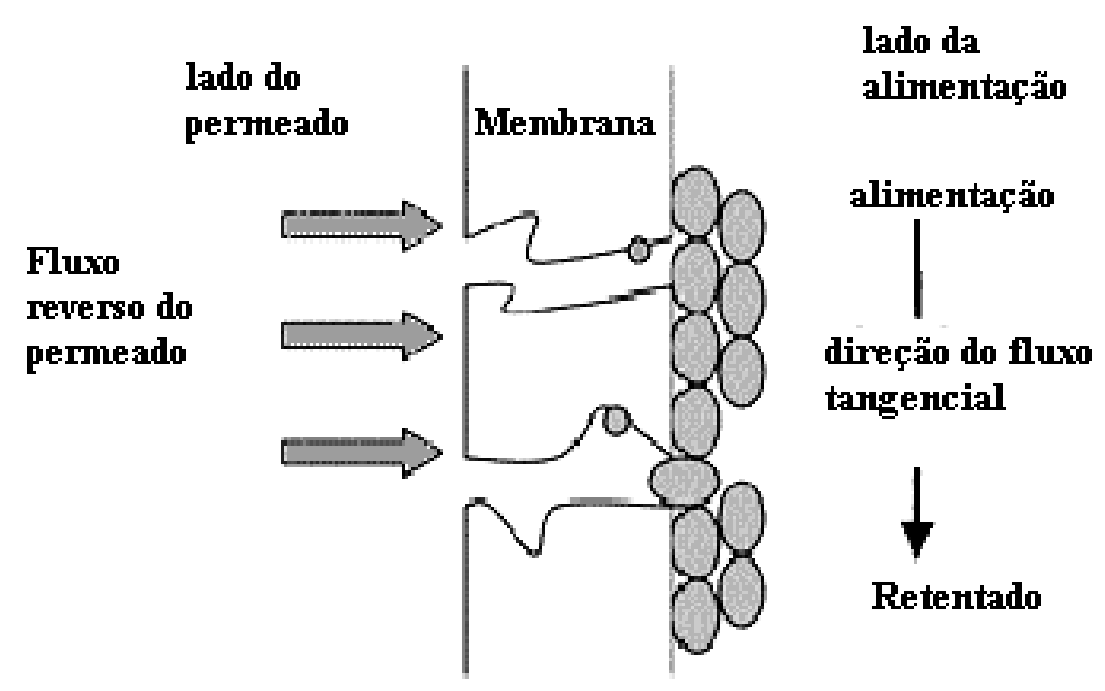

Figura 2. Representação esquemática da reversão de fluxo (Sondhi et al, 2003).

Esse fluxo reverso do permeado expulsa partículas depositadas dentro dos poros, que são carregadas para fora do módulo da membrana através do fluxo tangencial do retentado ou concentrado, ou então podem depositar-se novamente na superfície superior da membrana.

As membranas inorgânicas e de cerâmicas, geralmente, são encontradas na forma tubular, sendo de canal simples ou de multicanal. Cuidados especiais devem ser tomados com seus O-rings, gaxetas e tampões que são utilizados para manter seus elementos em suas posições. Em todos os módulos inorgânicos, a alimentação flui dentro dos canais, enquanto o permeado escoa através do suporte (CHERYAN, 1998).

Titânio $\left(\mathrm{TiO}_{2}\right)$ é sinterizado em material poroso dentro dos tubos para formar uma membrana de micro filtração permanente com tamanho de poro de $0,1 \mu \mathrm{m}$. Devido suas excelentes propriedades químicas e alta resistência à temperatura, são utilizadas em processos de alta temperatura, filtração crítica de lubrificação de óleos. As membranas de prata são atacadas pelos ácidos sulfúrico e nítrico, e como a maioria das membranas inorgânicas são muito caras. Existem também as membranas de alumínio (QUEIROZ, 2004).

\subsubsection{Processamento Cerâmico}

A sinterização é uma técnica de densificação do compacto cerâmico particulado. Ocorre essencialmente remoção dos poros entre as partículas unitárias (acompanhado de 
retração do componente), junto com o crescimento e forte união entre as partículas adjacentes, assim, o compacto cerâmico se torna uma massa coerente. Geralmente a energia de ativação e sustentação do processo de densificação é fornecida na forma de calor. A sinterização ocorre frequentemente através de três estágios de acordo com a seqüência das mudanças físicas. No primeiro estágio ocorre um rearranjo e início da formação de pescoço (figura 3).

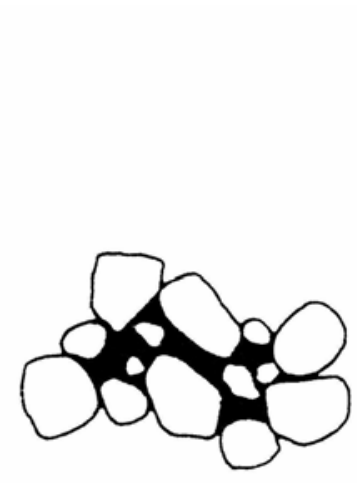

(a)

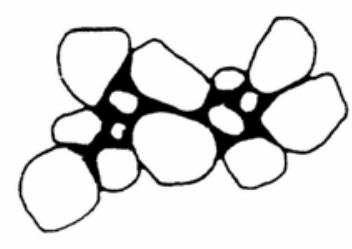

(b)

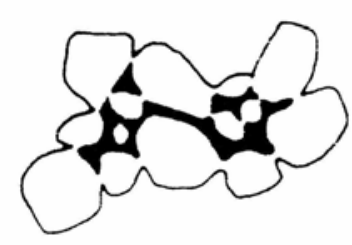

(c)

Figura 3. Mudanças durante o estágio inicial de sinterização. (a) início, (b) rearranjo, (c) formação do pescoço. (Richerson,1992)

No segundo estágio há um crescimento de pescoço, crescimento do grão e alta retração (figura 4).

.... fronteira

-

$\checkmark$ Porosidade

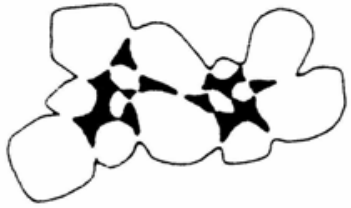

(a)

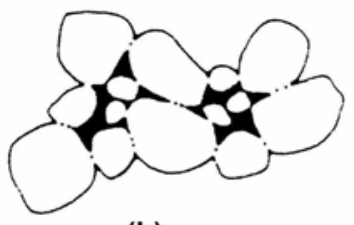

(b)

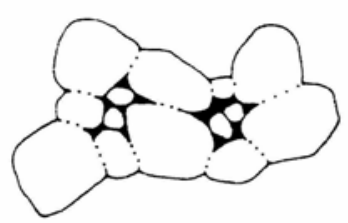

(c)

Figura 4. Mudanças ocorridas no segundo estágio. (a) crescimento do pescoço e retração no volume, (b) crescimento do pescoço e aumento do comprimento do contorno de grão, (c) crescimento de grão.

(Richerson,1992) 
No terceiro estágio ocorre grande crescimento de grão, fase porosa descontínua, crescimento dos contornos de grãos e posterior eliminação dos poros (figura 5).

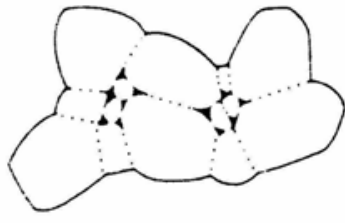

(a)

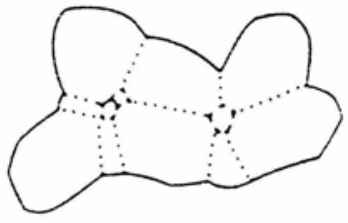

(b)

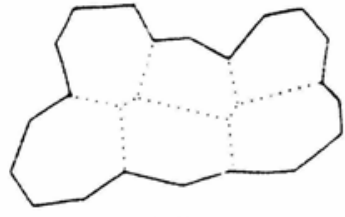

(c)

Figura 5. Mudanças no estágio final de sinterização. (a) crescimento de grãos e descontinuidade da fase dos poros, (b) crescimento de grão e redução da porosidade, (c) crescimento de grão com eliminação da porosidade. (Richerson,1992)

Durante a sinterização, as partículas se unem mais intimamente, reduzindo a porosidade. A força motriz necessária para esse processo é fornecida pela diminuição da energia superficial total, devido ao contato e crescimento entre os grãos. Os átomos dos grãos pequenos são transferidos para os maiores, e os poros são substituídos pelo material constituinte. Essa transferência de massa pode ser acompanhada por quatro mecanismos distintos, mas algumas vezes simultâneos. A tabela 1 apresenta estes mecanismos.

Tabela 1. Mecanismos de sinterização (FORTULAN et al, 1995).

\begin{tabular}{ccc}
\hline & Mecanismo de transporte & \\
Tipo de & de & Energia motriz \\
sinterização & material & \\
\hline Fase-vapor & Evaporação-condensação & Diferenças na pressão de vapor \\
\hline Estado-sólido & Difusão & Diferenças na energia livre ou \\
& & potencial químico \\
\hline Fase-líquida & Fluxo viscoso, difusão & Pressão capilar, tensão superficial \\
\hline Líquido reativo & Líquido viscoso, solução- & Pressão capilar, tensão superficial \\
& precipitação & \\
\hline
\end{tabular}


Os últimos anos tem tido um progresso importante na preparação de suportes de membranas e membranas suportadas. A pesquisa tem sido impulsionada pela preparação de membranas tendo a distribuição de tamanho de poros controlada acima de um estreito intervalo (RADHARANI DAS e DUTTA, 1999).

Radharanidas e Dutta (1999) apud Peterson et al. (1984), relataram a preparação de membranas alumina-titânia suportada, pela técnica sol-gel, iniciando com o precursor 2-metil-2-butóxido, e pôde alcançar poros pequenos o suficiente para interromper a passagem de moléculas com peso molecular menor que 200. O diâmetro médio do poro foi de aproximadamente $10 \mathrm{~nm}$. De Lange et al.(1995) também usaram a técnica sol-gel para preparar membranas $\gamma$-alumina suportada em $\alpha$-alumina pela camada imersa (dip coating). Eles modificaram assim as membranas preparadas por sobrepor uma camada adicional de sílica usando sílica sol (sílica em solução). Também preparam membranas usando soluções binárias de titânia, zircônia e alumina em combinação com sílica. As membranas mesoporosas produzidas foram testadas para separação de uma mistura de Hidrogênio $\left(\mathrm{H}_{2}\right)$ e Metano $\left(\mathrm{CH}_{4}\right)$.

\subsection{Misturas Emulsivas}

\subsubsection{Macro e Micro Emulsões - Teoria e Aplicação}

Misturando mecanicamente água e óleo, é possível produzir uma suspensão de gotículas de óleo em água ou, uma emulsão. A maionese é o exemplo mais comum. É possível produzir emulsões formadas por gotículas de água em fase contínua de óleo, como, por exemplo, manteiga. Em ambos os tipos de emulsão, a grande tensão interfacial entre a água e o óleo, acompanhada pela existência de grandes áreas interfaciais, implica a emulsão ter uma energia de Gibbs grande em comparação com as das fases individuais (CASTELLAN, 1986). Para suprir esta energia de Gibbs um trabalho mecânico é consumido, semelhante quando se agita rapidamente uma mistura. Assim, o processo de emulsificação implica num grande aumento de área interfacial $\left(\mathrm{S}_{1}\right.$ $\left.\rightarrow S_{2}\right)$, a qual leva a um aumento brusco da energia livre de superfície $\left(G_{1} \rightarrow G_{2}\right)$. Este fenômeno, em condições de temperatura constante, pode ser descrito pela Equação (2) (OLIVEIRA et al, 2004): 


$$
\Delta \mathrm{G}=\mathrm{G} 2-\mathrm{G} 1=\gamma i \times \Delta \mathrm{S}
$$

Na qual, $\gamma i$ representa a tensão interfacial entre as fases aquosa e oleosa.

Se considerarmos que o aumento da área interfacial $\left(S_{1} \rightarrow S_{2}\right)$ é imprescindível do ponto de vista tecnológico, uma das alternativas para estabilizar uma emulsão seria fornecer energia mecânica continuamente, de modo a manter a área interfacial aumentada. Este fator, embora necessário para a dispersão, por si só não é suficiente, pois vence a barreira da tensão superficial apenas temporariamente, enquanto durar a agitação. Então é possível verificar (através da equação 2) que o caminho mais viável para a estabilização do sistema é diminuir a tensão interfacial da dispersão, para reduzir a energia livre derivada da expansão da área interfacial. É possível verificar, também, que a estabilidade da emulsão deverá ser maior, quanto menor for a energia livre remanescente da expansão da área interfacial, tendendo a um sistema termodinamicamente estável, caso o aumento da energia livre seja totalmente compensado pela diminuição da tensão interfacial.

A adição superficial de um agente ativo (agente emulsificador), como um sabão ou detergente, ou qualquer molécula com uma extremidade polar e a outra formada por uma cadeia parafínica (apolar) longa, aos sistemas separados de óleo e água, diminui significativamente a tensão superficial, assim; a energia de Gibbs necessária para a formação da emulsão torna-se menor. A tensão interfacial decresce devido à adsorção dos agentes ativos na interface, com a extremidade polar na água e a cadeia parafínica no óleo.

As emulsões tradicionalmente preparadas com gomas naturais têm sido usadas em farmácias há séculos na administração de óleos e vitaminas. Na última década, entretanto, tem havido um novo interesse nas emulsões como veículo no desenvolvimento de drogas para o corpo, bem como o de encontrar características vantajosas que freqüentemente aumentam a biodisponibilidade da substância. Uma emulsão pode ser óleo em água ou água em óleo, designando assim as fases descontínua ou interna e contínua ou externa, respectivamente. Existem também as emulsões múltiplas que podem ser água-óleo-água ou óleo-água-óleo.

Emulsões podem ser definidas como sistemas heterogêneos de um líquido disperso em outro na forma de gotículas, normalmente, excedendo $0,1 \mu \mathrm{m}$ de diâmetro. Ambos os líquidos são parcialmente miscíveis, quimicamente não reativos e formam sistemas caracterizados por uma estabilidade termodinâmica mínima. Microemulsões 
são formadas espontaneamente, ao contrário das macroemulsões (tamanho de gotícula: 200 - $500 \mathrm{~nm}$ ) e miniemulsões (tamanho de gotículas: $100-400 \mathrm{~nm}$ ), as microemulsões são isotrópicas e termodinamicamente estáveis. Além disso, elas são opticamente transparentes porque as gotículas de óleo e água são bastante pequenas (10 $-200 \mathrm{~nm}$ ) no espalhamento de luz visível.

A menos que a energia livre da interface seja zero, uma emulsão não pode ser um sistema estável termodinamicamente desde que a redução da área em contato com a água resulte sempre da coalescência das gotículas. A estabilidade é um termo relativo, mas o grau de estabilidade pode ser assegurado pela observação da mudança da taxa de um parâmetro como a área interfacial ou diâmetro da gotícula (MOREIRA, 1994).

Quando dois líquidos imiscíveis são misturados, mantendo-se agitação constante, as duas fases tendem, inicialmente, a formar gotículas dispersas de um dos líquidos no interior do outro. Quando a agitação cessa, as gotículas tendem a coalescer e os líquidos separam-se novamente. Podemos, então, definir o tempo de vida de uma emulsão, como o tempo decorrido desde o momento em que os líquidos estão completamente homogeneizados, até a separação total do sistema. Assim, o "tempo de vida" é maior quanto melhor for a estabilidade do sistema.

Moreira (1994) apud King (1940), referiu-se a emulsões instáveis como óleos hidrossolúveis que coalescem rapidamente, enquanto emulsões estáveis podem reter uma fase interna altamente dispersiva por meses ou anos. Como a energia livre da interface dirige sua força para a coalescência, as emulsões podem ser estabilizadas pela inclusão de uma substância tensoativa no sistema que concentra a interface óleo-água $(\mathrm{O} / \mathrm{A})$.

A instabilidade de emulsões é manifestada na mudança das propriedades físicas da dispersão, como: a distribuição do tamanho das gotículas, as propriedades reológicas ou outros parâmetros que são uma conseqüência da coalescência das gotas ou da floculação, este termo se refere a uma significante alteração do diâmetro efetivo da gota antes da etapa de separação de fase, pode também afetar a aparência das emulsões líquidas e sólidas.

Quando uma emulsão água/óleo é instável, a decantação e processos de coalescência são adequados, por mais que a fase óleo em efluentes seja emulsificado na forma de emulsões estabilizadas. Neste caso, a desestabilização pela adição de reagentes químicos (ácidos, sais ou polieletrólitos) torna-se necessário antes da separação do óleo 
proveniente da fase aquosa por decantação, centrifugação, flotação, etc (NABI et al, 2000).

Várias técnicas fazem uso de centrífugas, células eletrolíticas, etc. Porém, o processo mais convencional e simples (flotação gravitacional) tem a sua aplicabilidade diminuída quando gotinhas de óleo caem na faixa abaixo de mícron. O problema tornase mais marcante quando surfactantes estão presentes na superfície da camada de gotículas de óleo, aumentando as forças repulsivas entre elas. Tais surfactantes são adicionados propositalmente à emulsão em indústrias siderúrgicas para aumentar sua estabilidade.

A filtração tangencial, quando usada na separação de fase, tem a vantagem de reduzir ou evitar o uso de reagentes químicos. Estudos na área de ultrafiltração de emulsões têm sido intensificados, acima de tudo com respeito à ultrafiltração na redução da quantidade de óleo em emulsões, sendo a influência das condições de operação o ponto principal da maioria desses estudos.

A lei de Stoke ilustra a importância do diâmetro das gotículas de óleo na separação de fase de uma mistura. De acordo com essa lei, a taxa de separação gravitacional depende da velocidade crescente da gotícula $v$, que é proporcional ao quadrado do diâmetro da gotícula $d$ (MENOM e WASAN, 1985):

$$
v=d^{2}\left(\rho_{\mathrm{w}}-\rho_{0)} \mathrm{g} / 18 \mu\right)
$$

sendo que g é a aceleração da gravidade, $\mu$ a viscosidade da água e $\left(\rho_{\mathrm{w}}-\rho_{0}\right)$ a diferença de densidade entre a fase água e a fase óleo, respectivamente. Portanto, ela é vantajosa para aumentar o tamanho da gotícula de emulsões estáveis em que o uso da separação gravitacional pode ser aplicado. Por exemplo, uma gotícula com tamanho de $1 \mu \mathrm{m}$ e densidade de $877 \mathrm{Kg} . \mathrm{m}^{-3}$ tem uma velocidade de aproximadamente $6 \times 10^{-8} \mathrm{~m} / \mathrm{s}$, enquanto uma gotícula de $10 \mu \mathrm{m}$ tem uma velocidade $6 \times 10^{-6} \mathrm{~m} / \mathrm{s}$. Em outras palavras, uma gotícula de $1 \mu \mathrm{m}$ leva aproximadamente $93 \mathrm{~h}$ para percorrer $2 \mathrm{~cm}$, ao contrário da de $10 \mu \mathrm{m}$ que leva $0,9 \mathrm{~h}$ para percorrer a mesma distância (HONG et al, 2003).

Nazzal and Wiesner (1996), investigaram os efeitos da pressão trans-membrana e tamanho dos poros. Eles encontraram que se as pressões trans-membranas estiverem abaixo da pressão crítica e rejeições da emulsão pode ser maximizada (HONG et al, 2003). Uma diferença importante entre membranas de mistura ou junção e membranas 
de rejeição é o fluxo potencial, o qual pode diferir por uma ordem de magnitude em favor da mistura ou união.

No trabalho de Nabi et al. (2000), foram feitas observações através de um microscópio óptico de emulsões com uma concentração de óleo consistindo entre 85 e 90\% em volume e de aparência muito opaca e leitosa, afirmando que essas emulsões eram do tipo (A/O). Diluindo essas emulsões com água resultou em uma mistura de fase aquosa com aglomerados de gotículas de óleo que dispersaram muito lentamente. Isso mostrou, portanto, que o processo de desestabilização dessas emulsões $\mathrm{A} / \mathrm{O}$, se ocorre, é lento. Portanto a concentração de óleo numa emulsão desse tipo é um fator relevante no processo de desestabilização.

\subsubsection{Aspectos Físico-Químicos de uma Emulsão e sua Interação com Membranas}

O problema da estabilidade de emulsões é um dos mais importantes e complexos em ciência coloidal. Também emulsões fortemente diluídas, limitando a interação dos pares, conhecimento incompleto das forças de superfície (forças hidrofóbicas e hidratação, influência de camadas adsorvidas, etc.) e processos dinâmicos (interações hidrodinâmicas entre gotas em curtas distâncias, deformação das gotas, dependência da interação de filmes entre elas, irreversibilidade da coagulação) que podem conduzir a modelos teóricos não confiáveis e a discrepâncias entre resultados teóricos e experimentais.

Nos últimos anos, vários trabalhos foram descritos a respeito da estabilidade de emulsões, eles repetem vários aspectos relacionados à capilaridade, reologia, interações, hidrodinâmica e transporte interfacial. Por esses trabalhos pode-se ver que as descobertas nessa área de pesquisa, promovem acontecimentos científicos relevantes para as propriedades física, química e hidrodinâmicas de emulsões.

O comportamento de emulsões depende da natureza da fase dispersa e o ambiente de dispersão, do método de formação da emulsão e importantes fatores que afetam subprocessos que ocorrem na preparação de emulsões.

P. Walstra e P.E.A. Smulders descreveram o processo de formação de emulsão, dando atenção a alguns métodos importantes e invenções para preparar emulsões e apresentaram uma análise detalhada da influência hidrodinâmica do escoamento laminar e turbulento, deformação da gota e movimento, viscosidade e adsorção de surfactantes 
na separação de gotículas pequenas dentro de gotas grandes. Também deram séria atenção ao papel da mudança na tensão superficial que causa escoamento próximo a uma interface óleo-água mais conhecido como efeito Marangoni (MISHCHUK et al, 2004).

A probabilidade de junção das gotículas é uma função das forças de interação e tensão superficial. Portanto, um estudo da coalescência e de sua dependência na concentração de diferentes misturas e das condições de preparação, são fatores significantes.

A presença de ar, bem como partículas sólidas, que é freqüentemente observada em várias indústrias ou emulsões naturais executam uma função importante na proporção e na taxa de agregação. Além disso, propriedades hidrofóbicas/hidrofílicas da superfície das partículas promovem efeitos antagônicos para diferentes tipos de emulsões. Por exemplo, isto foi mostrado por partículas hidrofílicas e hidrofóbicas de sílica que promoveram a estabilização de emulsões $\mathrm{O} / \mathrm{A}$ e $\mathrm{A} / \mathrm{O}$, respectivamente. Tal resultado é facilmente compreensível, porque no primeiro caso, as partículas se alojam na água e, no segundo caso, no óleo, ou seja; cria-se um impedimento estérico. Essas partículas também afetam as propriedades viscoelásticas das interfaces e, desta forma, aumentam a estabilidade da emulsão.

Mais de $80 \%$ do óleo cru explorado existe em um estado emulsivo, em todo o mundo. As emulsões mais comuns na indústria petrolífera são as do tipo água em óleo. A ocorrência de surfactantes em óleos cru tem sido grandemente identificada como responsável pela estabilidade dessas emulsões. A existência de surfactantes promove a estabilidade aparente de emulsões devido à formação de filmes rígidos ou altamente viscosos na interface óleo-água. Por razões operacionais e econômicas, é necessário separar a água completamente do óleo cru antes do transporte ou refino dele. Minimizando o nível de água no óleo é possível reduzir a corrosão no oleoduto e maximizar o seu uso (XIA et al, 2004).

Nabi et al (2000), estudaram o efeito da adsorção de uma emulsão de óleo de oliva pouco estabilizada ( $5 \%$ em óleo) e do óleo puro na superfície da camada de zircônia, em parte da membrana comercial (Carbosep) tubular, eles constataram que a gota de óleo desapareceu rapidamente por dentro dos poros por capilaridade, enquanto a emulsão de óleo em água permaneceu na superfície. Quando tentaram lavar a superfície com água destilada, só foi possível eliminar parte da emulsão. Diante dessas 
observações, puderam concluir que a superfície da membrana era altamente hidrofóbica.

Segundo Cheryan (1998), para a hidrofilicidade de um fluxo de alimentação aquoso, a membrana ideal deveria ser hidrofílica (atração por água); se o material é hidrofóbico, adsorverá componentes que são hidrofóbicos ou anfóteros, e isso pode causar o fouling. Por exemplo, muitas proteínas têm regiões hidrofóbicas dentro de sua estrutura que pode interagir altamente com materiais hidrofóbicos.

Uma medida da hidrofilicidade relativa de uma membrana é o ângulo de contato, que é a medida de quanto o líquido pode molhar a superfície em contato. Se uma gota de água é colocada em um material completamente hidrofílico, a água espalha-se na superfície, resultando em um ângulo de contato zero ou baixo. Um material hidrofóbico, por outro lado, repele a água, causando um alto valor no ângulo de contato. Materiais hidrofóbicos tendem a atrair óleo em um escoamento de resíduos de água oleosa, mas "hidrofilizando" a membrana poderia minimizar o óleo no fouling.

Em geral, o ângulo de contato de uma gotícula de óleo na superfície cerâmica da membrana em presença de água é maior do que $90^{\circ}$ isto é; a superfície da membrana é hidrofílica. Portanto, a pressão capilar é negativa (contrária à pressão hidráulica) e impede a entrada da gotícula de óleo pelo poro da membrana, conforme mostra a figura 3. Pressão hidráulica é comparável à pressão do retentado na operação de filtração (TING e WU, 1999).

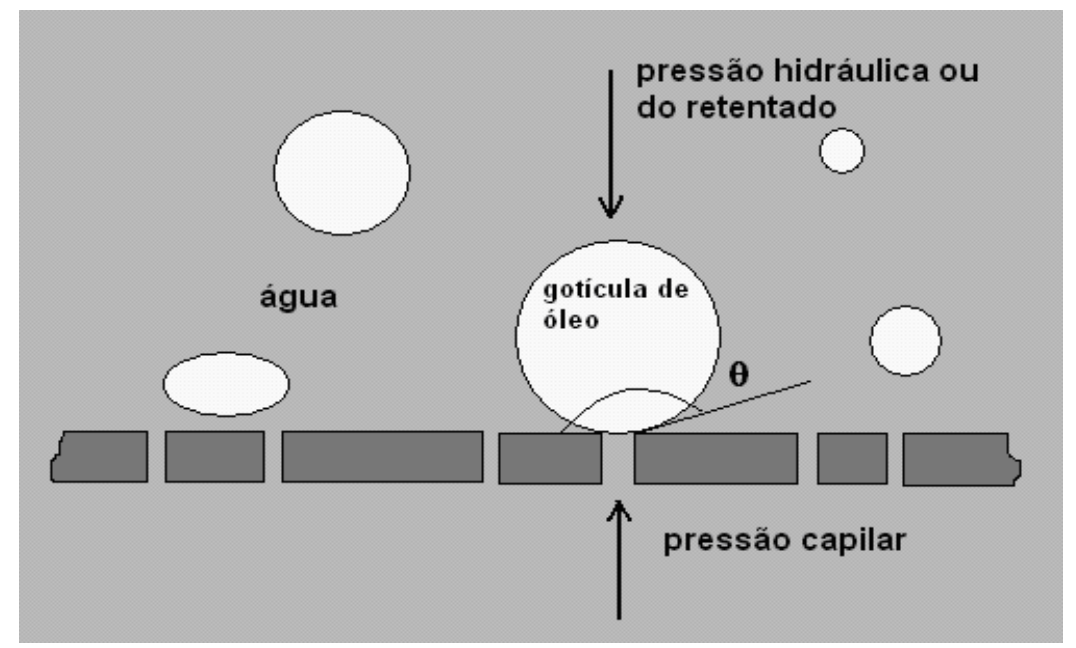

Figura 6. Princípio da rejeição da gotícula de óleo por pressão capilar na superfície da membrana adaptada de:TING e WU, 1999. 
Os materiais hidrofóbicos bem conhecidos tendem a apresentar altos ângulos de contato $\left(>100^{\circ}\right)$, enquanto alguns materiais cerâmicos, de celulose e especialmente hidrofilizados têm baixos valores $\left(<30^{\circ}\right)$.

A evidência parece indicar que a remoção de lipídeos no soro do leite por centrifugação ou micro filtração tem um efeito benéfico no fluxo deste processo. A evidência indireta do efeito nocivo de lipídeos no fluxo pode ser vista por comparar o fluxo durante a ultrafiltração do extrato da gordura total do grão de soja em água e extrato não gorduroso do grão de soja em água. No primeiro caso, o fluxo tornou-se independente da pressão a pressões relativamente baixas e foi muito baixo, enquanto no outro caso, o fluxo foi dependente da pressão durante todo o intervalo da pressão de operação e foi muito alto.

Com misturas água em óleo, deve ser lembrado que "semelhante atrai semelhante"; se membranas hidrofóbicas são usadas, óleo livre pode cobrir a membrana resultando num fluxo pobre (óleo emulsificado não é normalmente um grande problema, a não ser que esteja concentrado a um alto nível de tal maneira que a quebra da emulsão, libere óleo).

Emulsões água/óleo têm sido também feitas usando membranas hidrofílicas. Porém o tamanho resultante da gotícula é menor do que o tamanho do poro e é aparentemente dependente da estrutura do poro de saída e não estritamente do diâmetro.

Membranas adquiridas na forma hidrofílica podem ser transformadas para hidrofóbicas por modificação química. Esta possibilidade cria problemas em certas circunstâncias em que agentes acopladores silanos $\left(\mathrm{SiH}_{4}\right)$ são eliminados, tal como na indústria alimentícia. Pode ser necessário também repetir o tratamento superficial após cada ciclo de limpeza (JOSCELYNE e TRÃGARDH, 2000).

Membranas pré-umidecidas em soluções de surfactantes ou emulsificantes tem mostrado também melhora no fluxo da fase dispersada. A reduzida tensão interfacial nos poros conduz ao melhor preenchimento dos mesmos.

\subsubsection{Tratamento de Resíduos Industriais}

Alguns fluxos de águas residuárias industriais contêm uma considerável quantia de resíduos em óleos. Estes óleos provêm de lubrificantes de bicicletas, hidráulicos, 
instalações de impressão e processos de limpeza de metais e contêm partículas de todos os tamanhos. O óleo presente em água com resíduos pode ser separado por tecnologias comuns de separação. Uma sedimentação posterior serve para separação do óleo remanescente na água e partículas grossas. Após esse pré-tratamento, o óleo como resíduo pode ser usado como um substituto para óleo combustível com a finalidade de economizar os custos de energia. Entretanto, o uso de óleo reciclado causa uma fuligem e resíduos de combustão muito significantes comparados à utilização de óleo não reciclado.

Filtração é a separação de no mínimo dois componentes vindos do escoamento de um fluido, baseada primariamente nos tamanhos diferentes. Óleo, o fluido investigado neste caso, e água, tem algumas propriedades físicas e químicas em comum. Sendo, porém, a viscosidade do óleo investigado sete vezes maior do que a da água a $20^{\circ} \mathrm{C}$ (C. PSOCH et al, 2004).

De acordo com C. Psoch et al. (2004), Lai e Smith descreveram a filtração tangencial de óleo altamente viscoso (425 MPas a $80^{\circ} \mathrm{C}$ ) através de membranas tubulares cerâmicas (tubo único e multi canais). Com temperaturas entre 120 e $130{ }^{\circ} \mathrm{C}$, pressões trans-membrana de aproximadamente $500 \mathrm{KPa}$ e tamanhos de poro acima de $0,1 \mu \mathrm{m}$, eles obtiveram fluxos na faixa de $2,2-3,1 \mathrm{~kg} / \mathrm{m}^{2} \mathrm{~h}$. A vida útil para membranas a uma velocidade tangencial de aproximadamente $7 \mathrm{~m} / \mathrm{s}$ foi entre 10 e $12 \mathrm{~h}$.

Outros pesquisadores investigaram a filtração tangencial para óleo mineral usado através de membranas cerâmicas com multi canais. Os resultados foram satisfatórios. $\mathrm{O}$ grupo de pesquisa obteve um fluxo de $15,6 \mathrm{~kg} / \mathrm{m}^{2} \mathrm{~h}$ a uma temperatura de $80^{\circ} \mathrm{C}$ e velocidade tangencial de aproximadamente $6 \mathrm{~m} / \mathrm{s}$ (para poros com tamanho de $300 \mathrm{kD}$ e pressão trans-membrana de $1 \mathrm{MPa}$ ). Para a recuperação de tintas de impressão, membranas cerâmicas foram usadas com êxito em sistemas tinta/água. Poros com tamanho de 0,2 $\mu \mathrm{m}$ formam uma barreira suficiente para pigmentos coloridos. $\mathrm{O}$ alto custo de módulos cerâmicos limita seu uso para condições de operação extremas.

O processo de micro filtração é aplicado no tratamento de resíduos no processo de usinagem de metais, e na desemulsificação de misturas em processos particulares da engenharia de petróleo. Benito et al. (1999) estudaram um processo integrado com ultrafiltração para remoção de óleos em efluentes da indústria siderúrgica. O óleo contido no permeado proveniente do estágio de ultra filtração é $75 \%$ menor que os 
limites estabelecidos por todos os países da União Européia. Além disso, todas as partículas sólidas em suspensão foram removidas durante o estágio de ultra filtração.

Resíduos gordurosos ou oleosos em água constituem um dos maiores problemas ambientais em várias indústrias. A indústria têxtil usa água para remover óleos naturais. Indústrias automotivas e aeronáuticas usam água para uma variedade de limpezas e remover graxa de equipamentos por meio químico. Gorduras naturais animal/vegetal e óleos são gerados como produtos secundários (resíduos) em vários processos de fabricação de alimentos.

Por mais de 20 anos processos com membranas têm sido usados em processos de produção de alimentos e estão sendo usados gradativamente em técnicas de despoluição, particularmente devido à capacidade que têm de concentrar bioprodutos de interesse tais como: concentrar proteínas do soro do leite, reciclagem de tintas usadas em impressão e remoção de graxas de maquinários em indústrias de engenharia mecânica, recuperação de metais preciosos e compostos aromáticos, etc (NABI et al, 2000).

Emulsões óleo-água instáveis podem ser quebradas mecânica ou quimicamente e então separadas. Porém muitos desses escoamentos efluentes envolvem emulsões estáveis que são muito difíceis de quebrar devido à presença de detergentes (surfactantes) usados na limpeza e remoção de graxa de equipamentos. Essas emulsões podem ser tratadas quimicamente para produzir um sedimento (precipitado), que contém muito óleo e sujeira junto com quantia considerável de água. Esta sujeira precisa ser estabilizada para controle superior, e a fase aquosa precisa frequentemente ser tratada para favorecer a remoção de óleo residual e outros componentes orgânicos e inorgânicos (ZEMAN e ZYDNEY, 1996).

Ultra filtração fornece uma alternativa muito atrativa para este tipo de tratamento químico. As gotículas de óleo são completamente retidas pela membrana UF, já que a membrana é permeável ao óleo livre (solúvel). Ultra filtração de emulsões altamente estáveis produz permeado de água que pode ser despejado diretamente a um sistema municipal de águas residuais fora de qualquer outro tratamento. A fase óleo concentrada é geralmente menor que $5 \%$ do volume do resíduo original, o óleo pode ser reciclado, incinerado ou quimicamente tratado, dependendo da demanda específica do processo e economia.

Membranas hidrofílicas são normalmente usadas para filtrar esses resíduos oleosos em água, visto que membranas hidrofóbicas podem vir a ser encharcadas com o 
óleo e perder fluxo de água durante a operação. Membranas de celulose e poliméricas têm sido usadas para esse fim. As de celulose fornecem fluxo excelente e resistência ao fouling para o óleo de emulsões, mas tendem a degradar em $\mathrm{pH}$ alto e temperaturas altas, condições que são encontradas em várias aplicações.

Neste sentido, membranas cerâmicas e determinadas membranas poliméricas hidrofílicas, têm sido um dos métodos mais eficientes na separação de emulsões óleo/água. Comparada com a suspensão de sólidos, a separação de emulsões com membranas abre caminho para envolvimento adicional de fenômeno tais como: deformação da gotícula, coalescência ou equilíbrio da inversão de fase.

Há dois grupos responsáveis à resistência do fluxo do permeado durante a micro filtração, o primeiro grupo está interligado com a membrana e suas propriedades e ao bloqueio dos poros, e o segundo com a camada limite na membrana e a formação do fouling na interface da membrana. A seleção apropriada da membrana normalmente resolve a maioria dos problemas ligados ao primeiro grupo descrito acima. 


\section{METODOLOGIA}

\subsection{Preparação do Meio Micro Poroso}

\subsubsection{Sinterização do material cerâmico tubular}

O processo de desemulsificação foi estudado neste trabalho utilizando tubos cerâmicos de alta alumina micro poroso conformados pela Cetebra-Tecnicer Ltda. (São Carlos-SP). Foi analisado também o processo de impregnação da zircônia em concentrações diferentes, com o objetivo de avaliar o desempenho da desemulsificação de emulsões óleo vegetal/água através de um meio micro poroso tubular. Os tubos cerâmicos sofreram uma pré-queima ou foram sinterizados em uma mufla termoprogramada da temperatura ambiente até atingir temperaturas máximas de 1430, 1450,1470 e $1490{ }^{\circ} \mathrm{C}$, por $1 \mathrm{~h}$, com taxa de aquecimento de $10^{\circ} \mathrm{C} / \mathrm{min}$ e, posteriormente resfriados até $30^{\circ} \mathrm{C}$ a uma taxa de $10^{\circ} \mathrm{C} / \mathrm{min}$.

O objetivo desta queima preliminar era verificar através da análise de porosimetria por intrusão de mercúrio, o quanto a porosidade e distribuição de tamanho de poros do meio filtrante seriam sensíveis às variadas temperaturas estabelecidas para a sinterização, ou, determinar se essas propriedades características mudariam devido ao aumento da temperatura de sinterização. A análise porosimétrica foi realizada em um aparelho Autopore II/9220 - Micrometrics Instruments Corporation . Após essa análise, uma temperatura de sinterização foi selecionada para os tubos a serem impregnados.

\subsubsection{Obtenção do precursor da zircônia (solução de citrato de zircônio)}

O citrato metálico foi obtido através da dissolução simples de 0,2016 mols ou 38,74 g de ácido cítrico (Synth) em $500 \mathrm{~mL}$ de água destilada, sob agitação mecânica constante e aquecimento $\left(60-80^{\circ} \mathrm{C}\right)$. Após completa dissolução do ácido cítrico foram 
adicionados 0,0672 mols ou 21,9949 g de n-propóxido de zircônio (Aldrich), de 10 em $10 \mathrm{~mL}$ a cada 10 minutos. Depois da adição total do n-propóxido de zircônio, foi adicionado aproximadamente $8 \mathrm{~mL}$ de ácido nítrico (Synth), a fim de acelerar a solubilização do n-propóxido (que é evidenciada pela mudança de coloração da solução, de branca para incolor), após solubilização completa do mesmo, foi realizada uma filtração simples da solução, à frio. A solução foi introduzida em um balão volumétrico de $500 \mathrm{~mL}$, o qual foi aferido com água destilada para repor a água evaporada devido ao aquecimento da solução durante a sua preparação.

\subsubsection{Análise Gravimétrica}

Após o preparo da solução foi feita a gravimetria da mesma, com o objetivo de determinar a massa do metal (zircônio) presente na solução. Três cadinhos foram pesados em balança analítica, previamente lavados e secos, posteriormente, foram pesados com a solução de citrato de zircônio ( $8 \mathrm{~mL}$ da solução em cada cadinho) e então levados para calcinar em uma mufla termoprogramada até $800^{\circ} \mathrm{C}$ a $10^{\circ} \mathrm{C} / \mathrm{min}$ por 6 horas, após a calcinação da solução restou apenas o óxido de zircônio (zircônia) proveniente do seu precursor (citrato de zircônio).

$\mathrm{Na}$ análise gravimétrica, o constituinte a determinar é separado dos demais presentes no material em estudo, na forma de uma fase pura, que é então pesada. A partir do peso desta última acha-se o peso do constituinte desejado (OHLWEILER, 1976). O cátion metálico a ser determinado foi convertido em óxido de zircônio $\left(\mathrm{ZrO}_{2}\right)$ que pôde então ser pesado e assim determinar quantitativamente o metal desejado (zircônio) na solução, conforme a reação:

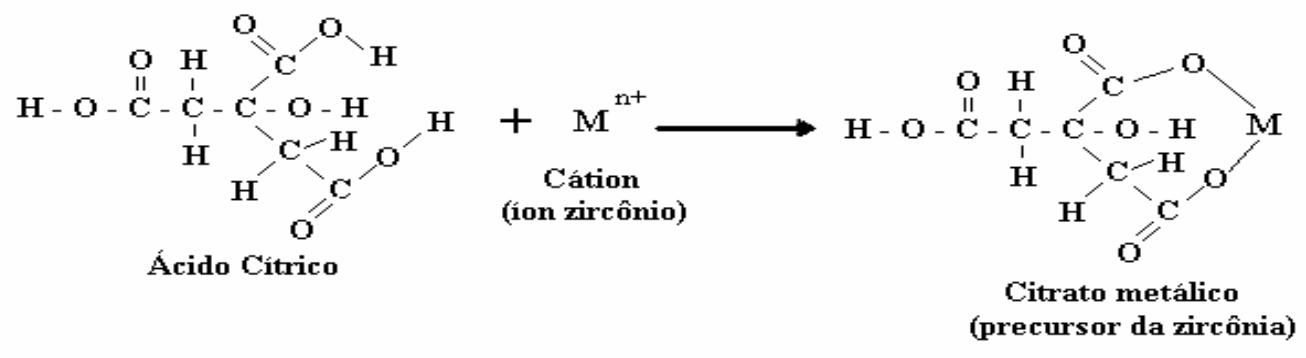

Figura 7. Reação química para produção do citrato metálico. 
Os resultados estão apresentados na tabela 1:

Tabela 2. Massa dos cadinhos e das amostras antes e após calcinação.

\begin{tabular}{cccc}
\hline $\begin{array}{c}\text { Cadinhos vazios } \\
(\mathbf{g})\end{array}$ & $\begin{array}{c}\text { Massa de citrato } \\
\text { de zircônio }(\mathbf{g})\end{array}$ & $\begin{array}{c}\text { Cadinhos + massa } \\
\text { de } \mathrm{ZrO}_{\mathbf{2}}(\mathbf{g})\end{array}$ & $\mathbf{Z r O}_{\mathbf{2}}$ (g) \\
\hline $\mathbf{3 5 , 6 3 0 8}$ & 5,5467 & 35,7457 & 0,1149 \\
\hline $\mathbf{3 5 , 1 8 2 4}$ & 5,4191 & 35,2439 & 0,0615 \\
\hline $\mathbf{3 9 , 7 6 3 7}$ & 5,5597 & 39,8281 & 0,0644 \\
\hline
\end{tabular}

A percentagem em peso de um constituinte em uma amostra é dada por:

$$
P=q / Q \times 100
$$

sendo que P é a percentagem do constituinte, q, o peso do constituinte achado na determinação e Q, o peso da amostra tomada para a análise.

1) $\mathrm{P}=0,1149 / 5,5467=0,0207$

2) $\mathrm{P}=0,0615 / 5,4191=0,0113$

3) $\mathrm{P}=0,0644 / 5,5597=0,0116$

Como o primeiro resultado é muito discrepante dos outros, este é descartado. $\mathrm{O}$ resultado médio de P é:

$$
(0,0113+0,0116) / 2=0,0114 \text { ou } 1,14 \% \text { de } \mathrm{ZrO}_{2}
$$

Estequiometria:

123,22 g de $\mathrm{ZrO}_{2} \rightarrow 91,22 \mathrm{~g}$ de $\mathrm{Zr}$

$$
\begin{gathered}
0,0114 \mathrm{~g} \rightarrow \mathrm{x} \\
\mathrm{x}=8,44 \times 10^{-3} \mathrm{~g} \text { de } \mathrm{Zr} \\
\text { média de } \mathrm{Q}=(5,4191 \mathrm{~g}+5,5597 \mathrm{~g}) / 2=5,4894 \mathrm{~g} \\
8,44 \times 10^{-3} \mathrm{~g} \mathrm{de} \mathrm{Zr} / 5,4894 \mathrm{~g}=1,54 \times 10^{-3} \mathrm{~g} \text { de } \mathrm{Zr} / \mathrm{g} \text { de solução } \\
1 \mathrm{~mol} \mathrm{de} \mathrm{Zr} \rightarrow 91,22 \mathrm{~g} \\
\mathrm{x} \rightarrow 1,54 \times 10^{-3} \mathrm{~g} \text { de } \mathrm{Zr}
\end{gathered}
$$




$$
\mathrm{x}=1,69 \mathrm{x} 10^{-5} \mathrm{mols} \text { de } \mathrm{Zr} / \mathrm{g} \text { de solução }
$$

Concentração de $\mathrm{Zr}$ na solução $=1,69 \times 10^{-5} / 0,5 \mathrm{~L}=3,38 \times 10^{-5} \mathrm{~mol} / \mathrm{L}$

\subsubsection{Impregnação}

O meio microporoso tubular foi impregnado com a solução de citrato de zircônio (precursor do óxido) da seguinte forma:

Colocou-se aproximadamente de 6-8 mL da solução citada anteriormente em uma proveta e introduziu-se o tubo microporoso, a solução foi gradualmente adsorvida pelo tubo por capilaridade, durante 12 horas, aproximadamente. Esse processo foi realizado em vários tubos. Após a impregnação nos tubos cerâmicos, os mesmos foram calcinados e tratados termicamente em uma mufla termoprogramada a temperaturas diferentes entre 100 e $600^{\circ} \mathrm{C}$, com tempos variáveis e taxa de aquecimento de $10^{\circ} \mathrm{C} / \mathrm{min}$ sob atmosfera de ar, sendo posteriormente resfriado até $30^{\circ} \mathrm{C}$ a uma taxa de $10^{\circ} \mathrm{C} / \mathrm{min}$. Alguns tubos sofreram tratamento térmico até $900^{\circ} \mathrm{C}$ com taxa de aquecimento e resfriamento de $10^{\circ} \mathrm{C} / \mathrm{min}$. O tratamento térmico ao qual os tubos cerâmicos foram submetidos tem a finalidade de eliminar toda a matéria orgânica presente na solução (citrato de zircônio) impregnada e a obtenção de nanopartículas do óxido metálico de interesse (zircônia).

Para se obter diferentes concentrações do óxido na estrutura microporosa tubular, os mesmos tubos foram impregnados novamente com a mesma solução e depois calcinados e tratados termicamente, conforme descrito anteriormente. Uma solução (citrato de zircônio) mais concentrada (2,07\%), obtida pelo mesmo procedimento da anterior, também foi utilizada para impregnação de outro tubo microporoso, para comparação com os tubos impregnados (uma e duas vezes) com a solução menos concentrada. Este processo de impregnação foi desenvolvido no Laboratório Interdisciplinar de Eletroquímica e Cerâmica (LIEC) da Universidade Federal de São Carlos (UFSCar), sob supervisão do Prof. Dr. Elson Longo.

\subsection{Ensaios e Equipamento Experimental}

Foi utilizada neste trabalho no processo de micro filtração, uma mistura de água e óleo de girassol em uma proporção de 1 vol \% de óleo de girassol na mistura ou numa relação volumétrica de 0,11 de óleo para 101 de água. A mistura foi produzida com 
água tratada de abastecimento pela agitação intensa num liquidificador, conduzindo a uma mistura homogênea ou uma emulsão estável.

No processo de micro filtração em estudo foram variados alguns parâmetros do processo, como: pressão trans-membrana e vazão da corrente de alimentação (que reflete diretamente na variação do número de Reynolds). A bancada experimental utilizada no estudo do processo é apresentada na figura 8.

Foram usados nos módulos de filtração tubos cerâmicos de alumina micro porosos e outros tratados quimicamente em concentrações diferentes de zircônia. Estes tubos apresentaram as seguintes medidas: tamanho de poro de $0,5 \mu \mathrm{m} ; 19,7$ a 22,7 cm de comprimento e 7,8 a 7,9 mm de diâmetro interno.

Através de uma bomba de escoamento positivo inclusa na bancada experimental, a mistura fluida que estava no tanque de alimentação manteve uma circulação constante, para se obter o filtrado livre de óleo. As pressões trans-membrana utilizadas foram: 2, 3, 4 e $5 \times 10^{5} \mathrm{~Pa}$ e a análise do processo foi realizada através das vazões do permeado medidas em função do tempo (200 min), o processo foi realizado continuamente durante todo o tempo, sem interrupções para mudanças de pressão. Durante todo o processo a temperatura ambiente de $25 \pm 0,5^{\circ} \mathrm{C}$ foi mantida por meio de um banho termostatizado e circulante no tanque de alimentação encamisado. 


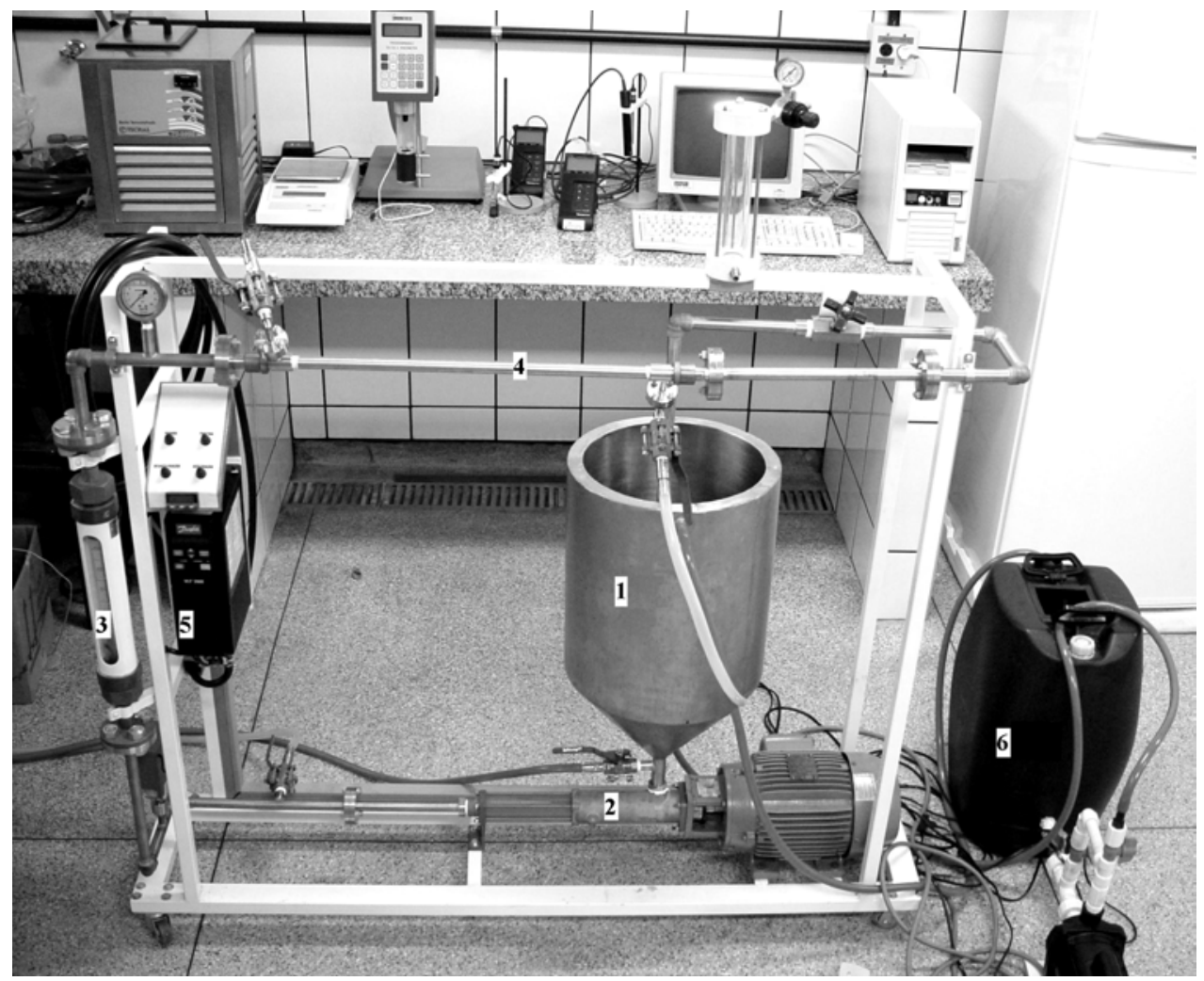

Figura 8. Bancada experimental. (1) - tanque de armazenagem da mistura; (2) - bomba de escoamento; (3) - rotâmetro; (4) - módulo com membrana; (5) - sistema de controle de aceleração da bomba e controle de temperatura; (6) - tanque de armazenagem de água fria ou quente.

O desempenho de cada tubo microporoso impregnado e não impregnado quimicamente foi verificado quanto à desemulsificação. Para cada experimento realizado (com cada tubo) a temperatura foi mantida constante $\left(25 \pm 0,5^{\circ} \mathrm{C}\right)$ e três velocidades médias, correspondente ao fluxo da alimentação $(2,96 ; 2,26$ e $1,82 \mathrm{~m} / \mathrm{s})$ foram fixadas para cada experimento, variando em cada uma delas apenas a pressão trans-membrana em função do tempo de filtração, tendo-se assim uma análise dinâmica do processo. Esse mesmo processo foi repetido usando um tubo micro poroso impregnado uma vez e queimado até $900^{\circ} \mathrm{C}$, com velocidades médias de: 2,$89 ; 2,28$ e $1,79 \mathrm{~m} / \mathrm{s}$. Os permeados eram recolhidos em intervalos de 5 minutos para cálculos posteriores e medidas das propriedades físico-químicas.

Uma série de experimentos foi realizada, tendo como parâmetros fixos a velocidade média do fluxo de alimentação, intervalo de tempo entre as medidas do permeado (15 min), com duração total do processo de 45 min e para cada tubo micro poroso usado (tubos impregnados uma e duas vezes, ambos queimados até $600 \mathrm{e}$ $900^{\circ} \mathrm{C}$ ), quatro pressões trans-membrana foram mantidas $\left(2,3,4\right.$ e $\left.5 \times 10^{5} \mathrm{~Pa}\right)$ 
respectivamente a cada experimento realizado. As velocidades médias foram de: 2,83 ; 2,$83 ; 2,83$ e $2,85 \mathrm{~m} / \mathrm{s}$; para os tubos: impregnado uma vez e queimado até $600^{\circ} \mathrm{C}$, impregnado duas vezes e queimado até $600^{\circ} \mathrm{C}$, impregnado uma vez e queimado até $900^{\circ} \mathrm{C}$ e impregnado duas vezes e queimado até $900^{\circ} \mathrm{C}$; respectivamente.

Foi utilizada também uma membrana comercial de origem alemã, com o valor nominal de tamanho de poro igual a $0,6 \mu \mathrm{m}$, e as dimensões: $40 \mathrm{~cm}$ de comprimento e $6,5 \mathrm{~mm}$ de diâmetro interno. A velocidade média para esse experimento foi de 3,61 m/s e pressões trans-membrana de 2,3 e $4 \times 10^{5} \mathrm{~Pa}$ (variadas sem interrupção do processo). Foi usado também um tubo cerâmico impregnado (uma vez) com uma solução de citrato de zircônio (2,07\%), queimado até 600 e $900^{\circ} \mathrm{C}$. As velocidades foram de 2,19 e 2,52 $\mathrm{m} / \mathrm{s}$, respectivamente, e as pressões trans-membrana de $2,3,4$ e $5 \times 10^{5} \mathrm{~Pa}$.

A limpeza do equipamento era realizada no término de cada experimento, através da circulação de água de torneira, durante cerca de 15 minutos, depois detergente neutro (EXTRAN MA 02 - MERCK) e a circulação de água novamente, até que o detergente e o resíduo da mistura (óleo) fossem eliminados. Em alguns tubos foi necessária uma limpeza adicional, deixando os tubos imersos numa solução com detergente enzimático MIX UF10 (Mixing Química Ind. e Comércio), a fim de recuperar a vazão trans-membrana para experimentos posteriores.

\subsection{Análise Físico-Química do Permeado}

Nos experimentos realizados foram medidas propriedades físico-químicas do permeado recolhido em intervalos de tempo previamente estabelecidos, essas propriedades são: vazão, pH, condutividade elétrica e Carbono Orgânico Total (TOC). Para o concentrado foi medida a viscosidade, densidade e TOC. Equipamentos Orion, modelo 115 e Orion, modelo 290 mediram respectivamente, condutividade elétrica e pH. A vazão foi calculada em $1 /\left(h^{2} \mathrm{~m}^{2}\right)$, sendo a massa do permeado medida em uma balança semi-analítica digital (Orkus). A viscosidade foi obtida através de um reômetro rotacional (Brookfield modelo DV-III+). O TOC foi medido no equipamento Shimadzu5000 A, disponível no laboratório de saneamento do Departamento de Hidráulica e Saneamento (SHS)-EESC/USP. 


\subsection{Caracterização da Mistura}

A mistura concentrada (emulsão) a ser filtrada foi analisada em microscópio óptico de campo claro - Leica DMLB, acoplado a um sistema de aquisição de imagens OPTRONICS e câmera de vídeo Sony modelo ICX-068 AK (disponibilizado pelo Laboratório de Processos Biológicos no Departamento de Hidráulica e SaneamentoEESC/USP). As imagens foram ampliadas 75 e 150 vezes, e o software Image Pro-plus (versão 3.0) foi usado para análise das imagens, que passaram por filtros morfológicos (Hi-Gauss) após calibração e, posterior tratamento e mensuração, a fim de obter uma distribuição do tamanho médio (diâmetro médio) das gotículas de óleo presentes na mistura.

Também foram realizadas medidas de ângulo de contato entre os líquidos (água, óleo e emulsão) e a superfície cerâmica microporosa (com e sem impregnação química), as amostras da superfície cerâmica foram utilizadas na forma de placas. A região de contato, mostrando o perfil da bolha, foi filmada com uma câmera (CCD) conectada a um microcomputador (disponível no Instituto de Física de São Carlos-Departamento de Física e Ciência dos Materiais/USP), as imagens captadas foram então analisadas com a ajuda do software - surftens 3.0 - para medida do ângulo de contato entre o líquido e a superfície a serem estudados. 


\section{RESULTADOS E DISCUSSÃO}

\subsection{Caracterização do Meio Microporoso}

Teoricamente, a altas temperaturas a estrutura do poro de cerâmicas porosas não é constante, devido à sinterização e/ou transformação de fase de materiais cerâmicos (CHANG et al, 1994). Embora membranas cerâmicas sejam conhecidas por terem muito mais estabilidade térmica do que membranas poliméricas, a sinterização e/ou transformação de fase pode mudar a estrutura dos poros de membranas cerâmicas porosas a elevadas temperaturas. Aplicações práticas dessas membranas cerâmicas a altas temperaturas, dependem dentre outras, da estabilidade térmica da estrutura dos poros dessas membranas. Uma membrana cerâmica sendo termicamente estável prova que as suas propriedades (composição química, estrutura de fase, tensão mecânica, e mais significativamente a estrutura do poro) permanecem inalteradas.

A técnica para análise de porosimetria por intrusão de mercúrio tem sido extensivamente utilizada para caracterização de uma importante propriedade de materiais porosos. A morfologia, o tamanho médio e o volume de poros abertos que um material poroso apresenta, pode torná-lo útil para uma aplicação específica, como filtros, membranas, catalisadores, concretos, cerâmicas, solos, papel, implantes ósseos dentre outros. Esta técnica foi proposta em 1921 por Washburn, que sugeriu ser possível obter a distribuição de diâmetros de poros a partir dos dados pressão em função do volume, durante a intrusão de mercúrio no material poroso. A técnica foi efetivamente aplicada por Henderson et al. em 1940 e vem sendo muito utilizada até então (MICROMETICS BRASIL).

A técnica se baseia no fato de que o mercúrio se comporta como um fluido "nãomolhante" em relação à maior parte das substâncias. Quando um líquido é colocado em contato com a superfície de um sólido sem haver reações químicas ou dissolução do sólido pelo líquido, o mesmo irá se espalhar pela superfície até certa geometria de 
equilíbrio. A tensão superficial do mercúrio é alta, cerca de $485 \mathrm{dina} / \mathrm{cm}^{3}$, isso mostra a tendência que o mercúrio tem em se contrair para uma forma de área específica mínima, devido a forças intermoleculares em sua superfície. Portanto o mercúrio apresenta altos ângulos de contato com a maioria dos sólidos (em torno de $130^{\circ}$ ). Todas essas características fazem com que o mercúrio seja o único líquido utilizado na porosimetria por intrusão, quando o mercúrio é colocado em contato com uma amostra porosa este não consegue penetrar seus poros. Para isso é necessária uma força externa (pressão) que supere a tensão superficial do mercúrio e o ângulo de contato entre o mercúrio e o material.

De acordo com Viviani (1992) apud Sridharan et al (1971), Washburn sugeriu que a distribuição de vazios dos materiais porosos poderia ser medida pelo aumento da pressão em pequenos incrementos, anotando-se o volume do líquido intrudido a cada um desses acréscimos e considerando-se os poros capilares cilíndricos. A desvantagem da aplicação da Equação de Washburn está no fato de os poros não serem normalmente circulares, levando assim a resultados somente comparativos. Outras desvantagens são observadas quando poros com formato "pote de tinta" estão presentes, pois a pressão necessária à penetração do mercúrio será função apenas do diâmetro da abertura do poro (TEIXEIRA et al, 2001).

A distribuição de tamanhos de poro pode ser dada pelas funções de distribuição $d V / d r, d V / d \log r$ ou $d V / d \ln r$ em função do raio do poro, onde $d V$ é a variação de volume de poros quando o raio de um poro cilíndrico varia de $r$ a $r$ - $d r$. Normalmente, as funções logarítmicas são utilizadas por reduzir a grande faixa de valores de volume que deve ser utilizada no caso da primeira função. Nos gráficos de distribuição $d V / d r$, $d V / d \ln r$ e $d V / d \log r$ versus $r$, a altura da curva em qualquer ponto ao longo do eixo de $r$ reflete não só o volume de intrusão naquele ponto, mas também o fato de que o valor numérico da função é determinado pela pressão na qual aquele volume penetrou.

O equipamento usado para porosimetria por intrusão de mercúrio consiste em: um penetrômetro, um dispositivo de enchimento, uma bomba de vácuo e um manômetro. O princípio de operação desse equipamento é baseado no seguinte: o penetrômetro, contendo uma amostra em tamanho apropriado, é colocado no dispositivo de enchimento, o qual está conectado a uma bomba de vácuo, que permanece ligada ao sistema por aproximadamente 30 minutos, com a finalidade de evacuar a amostra. Terminado o período de vácuo o penetrômetro é preenchido com mercúrio, através de 
uma válvula que permite entrada de ar, até que seja atingida a pressão atmosférica. $O$ penetrômetro é então transferido para uma câmara de pressão, contendo álcool isopropílico, onde pressões de 0 a 5000 psi $(34500 \mathrm{KPa})$ podem ser aplicadas ao mercúrio (em alguns equipamentos essa pressão pode chegar a 15000 psi ou 103500 $\mathrm{KPa}$ ). A pressão é aumentada gradativamente e o mercúrio vai sendo forçado a entrar em poros com tamanhos cada vez menores, sendo o volume de mercúrio intrudido indicado no próprio penetrômetro, através de uma haste capilar graduada. Registrandose a redução do nível de mercúrio no capilar juntamente com a pressão aplicada, uma curva porosimétrica é obtida informando que volume de poros do material foi penetrado pelo mercúrio a uma dada pressão (VIVIANI, 1992).

Amostras do material cerâmico sinterizado foram retiradas para a análise de porosidade e distribuição de tamanho de poros, através da técnica de porosimetria por intrusão de mercúrio. Os resultados da análise porosimétrica para o material cerâmico em estudo são apresentados a seguir.

A análise de porosimetria por intrusão de mercúrio sugere micro porosidade para todas as temperaturas de sinterização, como mostra a figura 9. É possível observar também que o tamanho médio de poros no meio microporoso tubular é de aproximadamente $0,5 \mu \mathrm{m}$, indicando que o tamanho médio de poros de cada material (tubos) não foi sensível à taxa de variação de temperatura.

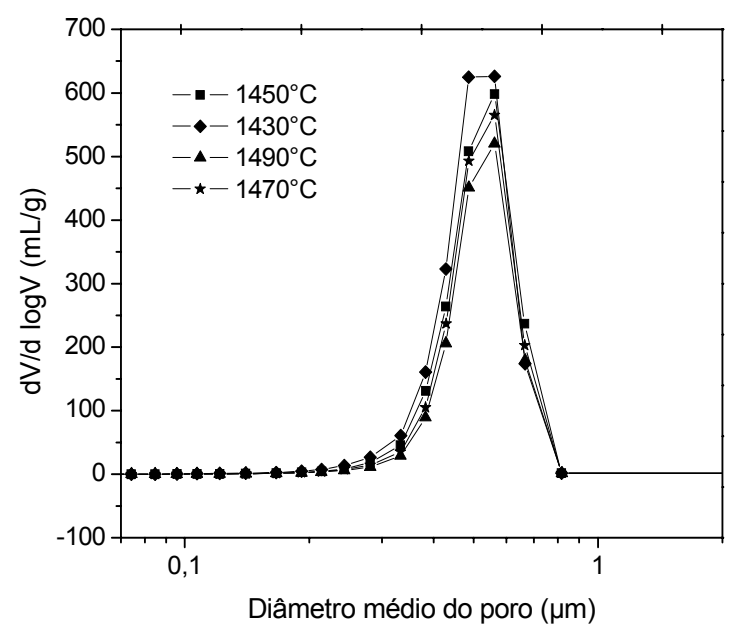

Figura 9. Análise de porosimetia por intrusão de mercúrio dos tubos cerâmicos sinterizados a diferentes temperaturas. 


\subsection{Análise dos Resultados do Processo de Micro Filtração}

No processo de micro-filtração estudado neste trabalho, foi possível obter resultados do fluxo trans-membrana $\left(1 / \mathrm{h} \mathrm{m}^{2}\right)$ em função do tempo (minutos) de processamento da desemulsificação de misturas água e óleo de girassol. Os experimentos foram realizados a partir da produção de emulsões com concentração de $1 \%$ em massa, na temperatura de $25^{\circ} \mathrm{C}$ e em geral com duração de 200 min de processamento. Os tubos micro-porosos foram ensaiados numa experimentação dinâmica, ou seja, sem interrupção do processo e com variação de pressão transmembrana submetida nos valores de 2, 3, 4 e 5 bar. Os tubos micro-porosos, caracterizados pela técnica de porosimetria por intrusão de mercúrio apresentaram tamanho de poros no valor de $0,5 \mu \mathrm{m}$. O regime de escoamento em todos os experimentos foi turbulento.

Os resultados do fluxo trans-membrana em função do tempo são apresentados na figura 10 para três valores de Reynolds, correspondente a cada experimento realizado. Os valores do número de Reynolds para cada tubo (conforme apresentado na figura 10), foram calculados da seguinte maneira: primeiro foi necessário calcular a vazão média $\left(\mathrm{Q}_{\text {médio }}\right)$ do meio fluido (vazões correspondentes a cada pressão transmembrana de 2, 3, 4 e 5 bar) em três velocidades médias diferentes. Por exemplo, para o tubo impregnado uma vez a $600^{\circ} \mathrm{C}$, obteve-se:

$$
\mathrm{Q}_{\text {médio }}=116,05 \mathrm{~g} / \mathrm{s} \text { ou } 1,16 \times 10^{-4} \mathrm{~m}^{3} / \mathrm{s}
$$

e consequentemente, a velocidade média:

$$
\begin{gathered}
u=\mathrm{Q} / \text { Área tubo }\left(\pi \mathrm{r}^{2}\right) \text { ou } \\
u=1,16 \times 10^{-4} \frac{\mathrm{m}^{3}}{\mathrm{~s}} \div 4,90 \times 10^{-5} \mathrm{~m}^{2}=2,37 \frac{\mathrm{m}}{\mathrm{s}} .
\end{gathered}
$$

Foi necessário obter também outros valores: densidade $(\rho)$ e viscosidade $(\mu)$ do concentrado e diâmetro interno do tubo cerâmico $(d)$. Tendo esses valores o número de Reynolds pôde ser calculado conforme a Equação 5 (CHERYAN,1998): 


$$
\operatorname{Re}=d V \rho / \mu
$$

Substituindo os valores obteve-se:

$$
\operatorname{Re}=7,9 \times 10^{-3} \mathrm{~m} \times 2,37 \frac{\mathrm{m}}{\mathrm{s}} \times 997 \frac{\mathrm{kg}}{\mathrm{m}^{3}} / 1,1 \times 10^{-3} \mathrm{~Pa} . \mathrm{s}=16970
$$

Outros valores com relação à velocidade média $(u$ ou $V)$ e o respectivo número de Reynolds foram obtidos para o mesmo tubo: $u=3,16 \mathrm{~m} / \mathrm{s}$ e $\operatorname{Re}=22600 ; u=1,86 \mathrm{~m} / \mathrm{s}$ e $\operatorname{Re}=13318$. Para o tubo impregnado duas vezes a $600^{\circ} \mathrm{C}$ obteve-se: $u=2,84 \mathrm{~m} / \mathrm{s}$ e $\operatorname{Re}$ $=20335 ; u=2,29 \mathrm{~m} / \mathrm{s}$ e $\operatorname{Re}=16397 ; u=1,83 \mathrm{~m} / \mathrm{s}$ e $\operatorname{Re}=13103$, com diâmetro interno $=7,9 \times 10^{-3} \mathrm{~m}$. Para o tubo sem impregnação: $u=3,14 \mathrm{~m} / \mathrm{s}$ e $\operatorname{Re}=22483 ; u=2,18 \mathrm{~m} / \mathrm{s} \mathrm{e}$ $\operatorname{Re}=15609 ; u=1,76 \mathrm{~m} / \mathrm{s}$ e $\operatorname{Re}=12602$, com diâmetro interno $=7,9 \times 10^{-3} \mathrm{~m}$.

É possível observar nos gráficos da figura 10 uma semelhança no comportamento do fluxo. Em cada mudança da pressão trans-membrana, correspondente aos intervalos de $50 \mathrm{~min}$, há um aumento abrupto no fluxo transmembrana. Também se observa que para os maiores valores de Reynolds (figura 10 (a) e (b)), a cada variação de pressão, os maiores valores do fluxo trans-membrana são atingidos para o tubo impregnado uma vez, inclusive para a maior parte do processo.
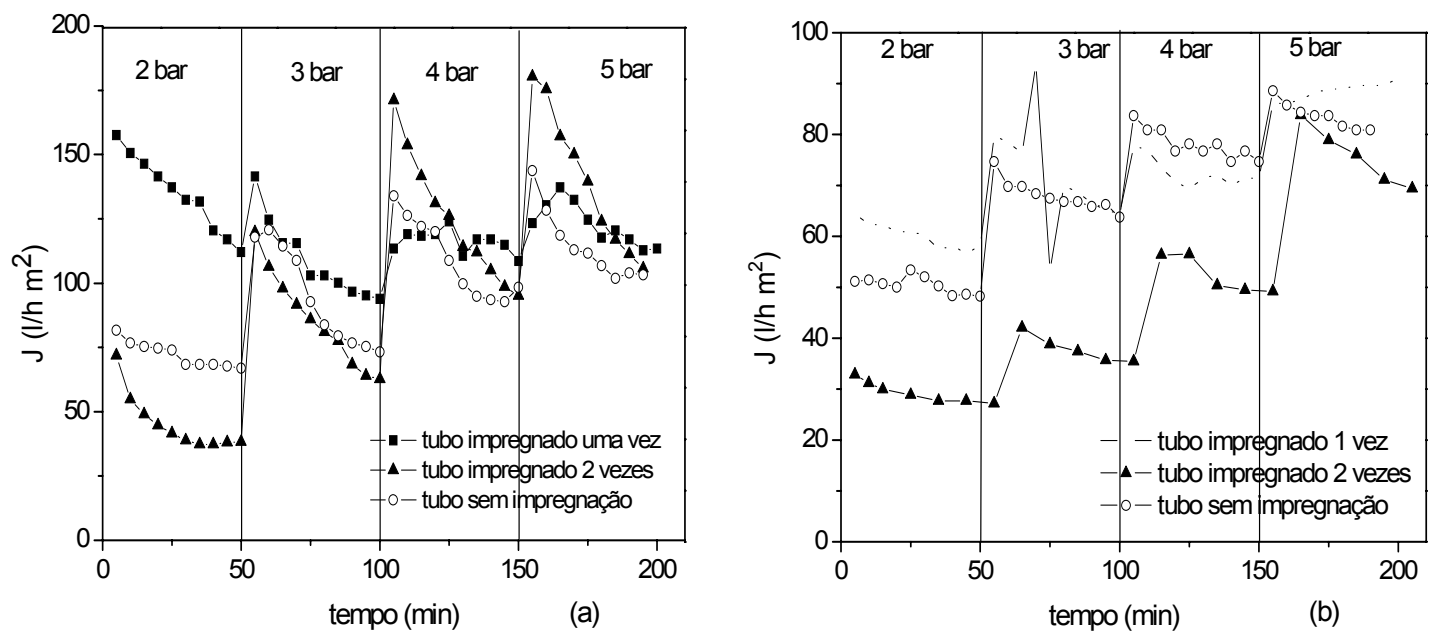


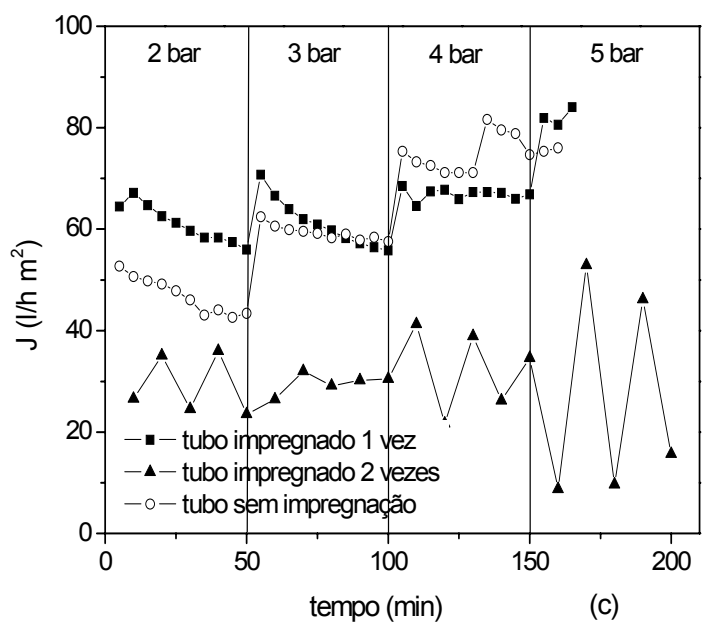

Figura 10. Fluxo trans-membrana em função do tempo, para os tubos impregnados queimados até $600^{\circ} \mathrm{C}$ e tubo sem impregnação. Reynolds: $R e \sim 20000$ (a); $R e \sim 16000$ (b); $R e \sim 12000$ (c).

A figura 10 (c) mostra um comportamento diferente para o tubo impregnado duas vezes, em relação aos outros casos (figura 10 (a) e (b)), pois ocorre uma variação descontrolada do fluxo trans-membrana e não há no processo a estabilização típica da camada de polarização (ZEMAN e ZYDNEY, 1996). A presença de mudanças abruptas no fluxo trans-membrana nas condições investigadas (figura 10 (c)), é devida provavelmente a interações superficiais entre a emulsão e a micro estrutura porosa, que são predominantes em relação à tensão de cisalhamento da corrente principal.

A figura 11 apresenta os resultados experimentais do fluxo trans-membrana (permeado) em função do tempo, para experimentos realizados com tubo impregnado uma vez em temperatura de calcinação de $900^{\circ} \mathrm{C}$ e tubo impregnado uma vez com a solução mais concentrada $(2,07 \%)$ com temperaturas de queima de 600 e $900^{\circ} \mathrm{C}$; com tamanho de poro médio de $0,5 \mu \mathrm{m}$, diâmetro interno $=8,36 \times 10^{-3} \mathrm{~m}, u=2,19 \mathrm{~m} / \mathrm{s}$ e $\operatorname{Re}=$ 16594, para o tubo impregnado a $600^{\circ} \mathrm{C}$ e $u=2,52 \mathrm{~m} / \mathrm{s}$ e $\mathrm{Re}=19094$ para o tubo impregnado a $900^{\circ} \mathrm{C}$. Os experimentos foram conduzidos como anteriormente (figura 10). Na figura 11(a), os experimentos foram realizados para três Reynolds diferentes: $\operatorname{Re}=20431 ; \operatorname{Re}=16119 ; \operatorname{Re}=12655$, com velocidades médias: 2,89, 2,28 e 1,79 m/s e diâmetro interno $=7,8 \times 10^{-3} \mathrm{~m}$; com objetivo de avaliar a influência da variação do número de Reynolds como parâmetro fluidodinâmico. 

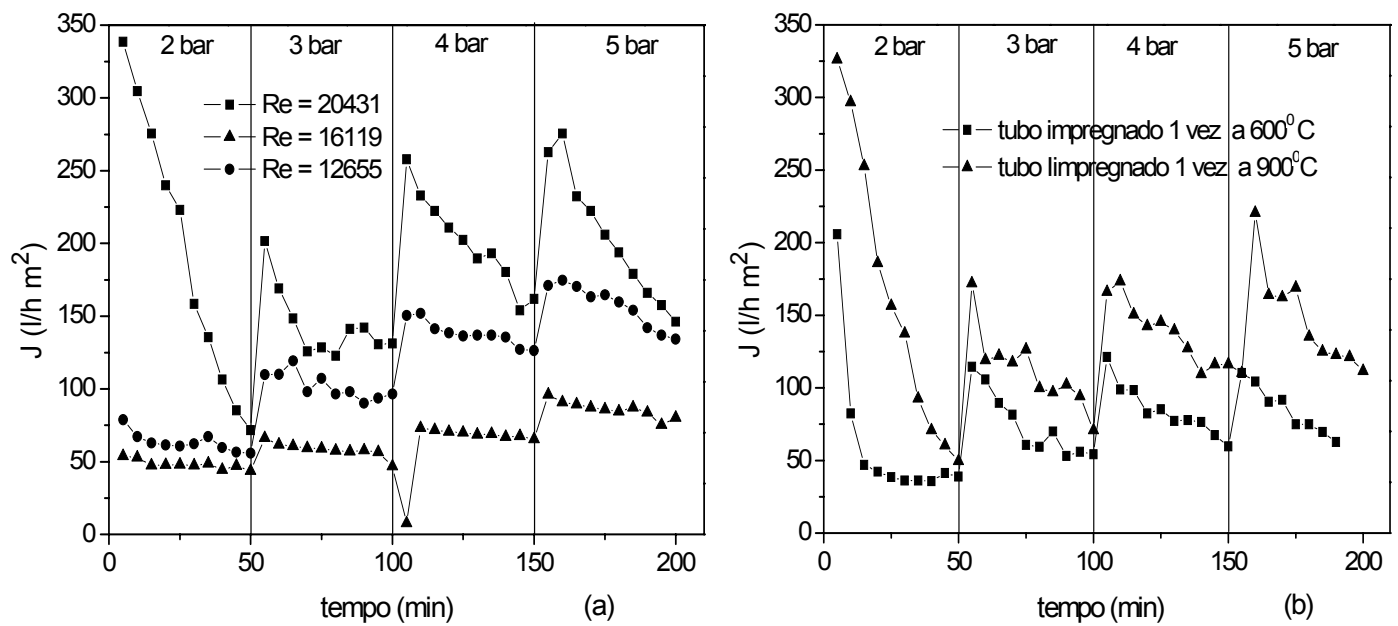

Figura 11. Fluxo trans-membrana em função do tempo para tubo impregnado uma vez a $900^{\circ} \mathrm{C}$ (a); tubo impregnado com solução $(2,07 \%)$ a 600 e $900^{\circ} \mathrm{C}$ (b).

$\mathrm{Na}$ figura 11 (b), os experimentos foram realizados para $\mathrm{Re}=16594$ e $\mathrm{Re}=$ 19094, que corresponde respectivamente aos tubos impregnados até 600 e $900^{\circ} \mathrm{C}$. Em ambos os casos (figura 11 (a) e (b)) nota-se que os maiores fluxos foram obtidos para os maiores Reynolds logo no início do processo (correspondente a menor pressão transmembrana $=2$ bar), isso se deve à ausência da formação da camada de resistência gel polarizada, que tende a estabelecer no inicio do processo. No decorrer do processo, o fluxo aumenta progressivamente a cada aumento de pressão, ou seja; ao término de cada intervalo de $50 \mathrm{~min}$, mas diminui em relação ao início do processamento na nova pressão trans-membrana.

É possível observar também que a temperatura de calcinação após impregnação dos tubos interferiu no fluxo trans-membrana (fig.11(b)), já que o tubo impregnado e queimado a $900^{\circ} \mathrm{C}$ alcançou os maiores valores de vazão em relação ao tubo impregnado a $600^{\circ} \mathrm{C}$.

A figura 12 mostra o desempenho no processo de desemulsificação dos tubos impregnados uma e duas vezes e queimados a temperaturas de 600 e $900^{\circ} \mathrm{C}$, para uma série de experimentos realizados de forma estática, ou seja, com parâmetros fluidodinâmicos (velocidade média, Reynolds e pressão trans-membrana) mantidos constantes durante o processo com duração de $45 \mathrm{~min}$. Cada experimento foi conduzido a uma pressão trans-membrana constante de: 2, 3 e 4 bar. Os números de Reynolds para os tubos impregnados uma e duas vezes e queimados a $600^{\circ} \mathrm{C}$ e impregnados uma e 
duas vezes e queimados a $900^{\circ} \mathrm{C}$ foram respectivamente: $\mathrm{Re}=20263 ; \mathrm{Re}=20263$ e $\mathrm{Re}$ $=20407$, tendo diâmetro interno $=7,9 \times 10^{-3} \mathrm{~m}$.
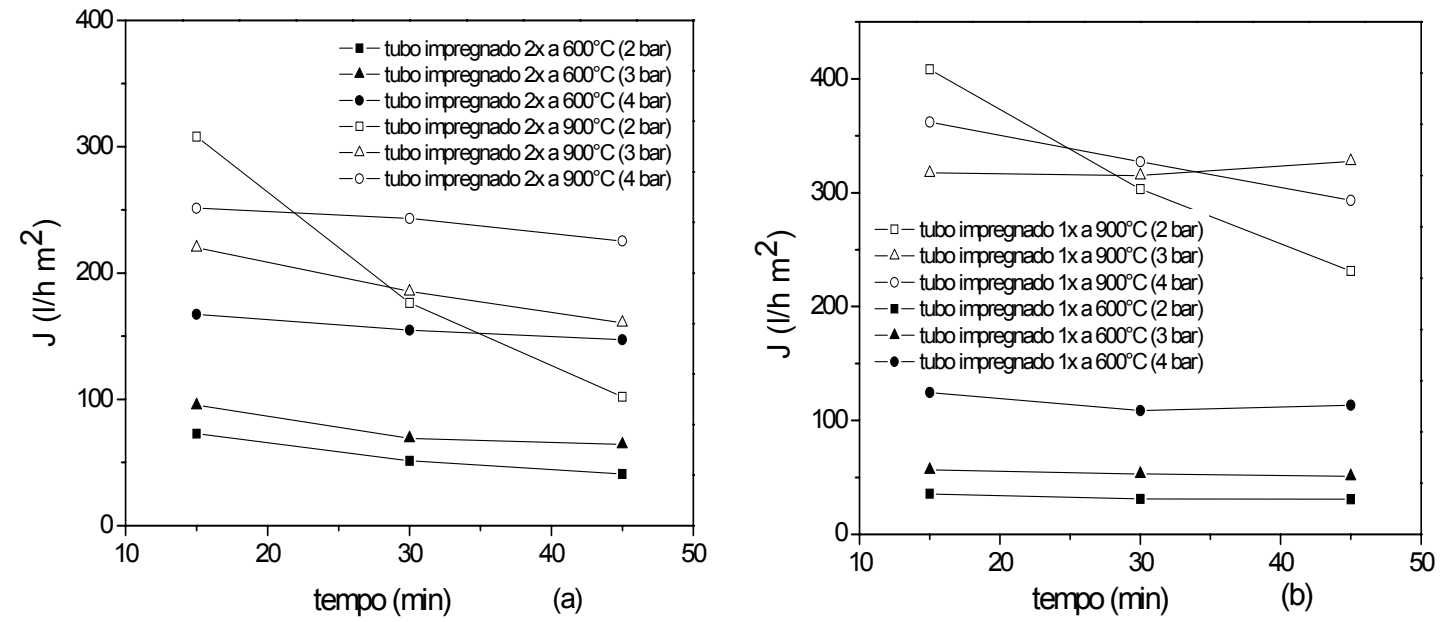

Figura 12. Fluxo trans-membrana em função do tempo para um processo estático: tubos impregnados 2 vezes até 600 e $900^{\circ} \mathrm{C}$ (a); tubos impregnados 1 vez até 600 e $900^{\circ} \mathrm{C}(\mathrm{b})$.

Observa-se na figura 12 que os maiores fluxos trans-membrana foram obtidos na maior pressão trans-membrana (4 bar), para os quatro tubos usados (tubos impregnados uma e duas vezes, e ambos queimados a 600 e $900^{\circ} \mathrm{C}$ ). Isto é esperado, uma vez que um aumento na pressão trans-membrana conduz ao aumento no fluxo trans-membrana (CHERYAN, 1998).

Os gráficos mostram também que os tubos impregnados e queimados a $900^{\circ} \mathrm{C}$, fornecem maiores valores de fluxo trans-membrana em relação aos tubos impregnados e queimados a $600^{\circ} \mathrm{C}$. Isto indica, portanto, que a temperatura de calcinação após a impregnação na micro estrutura cerâmica, é um fator que interferiu no desempenho dos tubos estudados, possivelmente devido à mudança na estrutura cristalina que as nano partículas de zircônia adquirem, durante o tratamento térmico ao qual são submetidas.

As figuras a seguir apresentam os resultados experimentais para o fluxo adimensional $(\mathrm{J} / \mathrm{u})$ através dos tubos cerâmicos micro porosos, onde $\mathrm{J}$ é o fluxo transmembrana, e u a velocidade média da corrente de alimentação no tubo; em função do adimensional $\Delta \mathrm{P}_{\mathrm{tm}} / \rho . \mathrm{u}^{2}$, sendo $\Delta \mathrm{P}_{\mathrm{tm}}$ a pressão trans-membrana e $\rho$ a densidade do permeado, caracterizado fisicamente como água. 
Para o processo de desemulsificação alguns parâmetros são fundamentais, $\mathrm{J}=\phi$ $\left(\Delta \mathrm{P}_{\text {tm }}, \Delta \mathrm{P}, \mu, \rho, \mathrm{u}, \mathrm{d}\right)$ que representam a pressão trans-membrana, a queda de pressão da corrente principal, viscosidade, densidade, velocidade média e diâmetro do tubo; respectivamente. O parâmetro adimensional " $\Delta \mathrm{P} / \rho . \mathrm{u}^{2 \text { " }}$ é chamado número de Euler, e tem interesse na literatura (STOPKA et. al., 2001) pois se correlaciona com o adimensional de Reynolds. Neste trabalho o adimensional de Euler foi modificado para a pressão trans-membrana, como " $\Delta \mathrm{P}_{\mathrm{tm}} / \rho . \mathrm{u}^{2}$ ", e foi analisado em função do inverso da velocidade média $(\mathrm{u})$ inclusa no adimensional " $\mathrm{J} / \mathrm{u}$ ".

As figuras 13 a 15 apresentam os resultados adimensionais para o processo com os tubos impregnados em concentrações diferentes, queimados a temperaturas de até 600 e $900^{\circ} \mathrm{C}$, e para tubo não impregnado. Os resultados são referentes ao processo dinâmico a $25^{\circ} \mathrm{C}$, com variação de pressão trans-membrana nos valores de: 2,3 , 4 e 5 bar e velocidade média a cada tubo ensaiado. Os valores apresentados abaixo correspondem às vazões trans-membrana no final do processamento ( $\mathrm{t}=50 \mathrm{~min}$.), correspondente a cada valor da pressão trans-membrana.
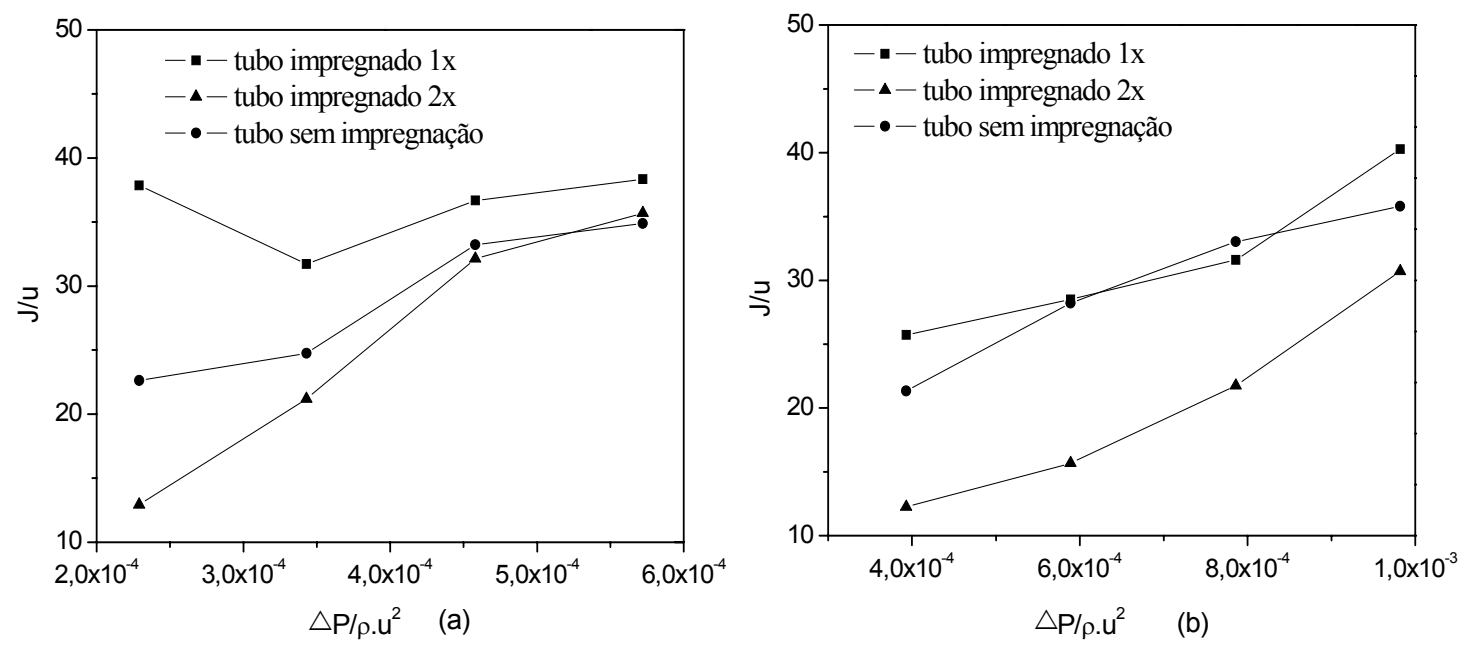


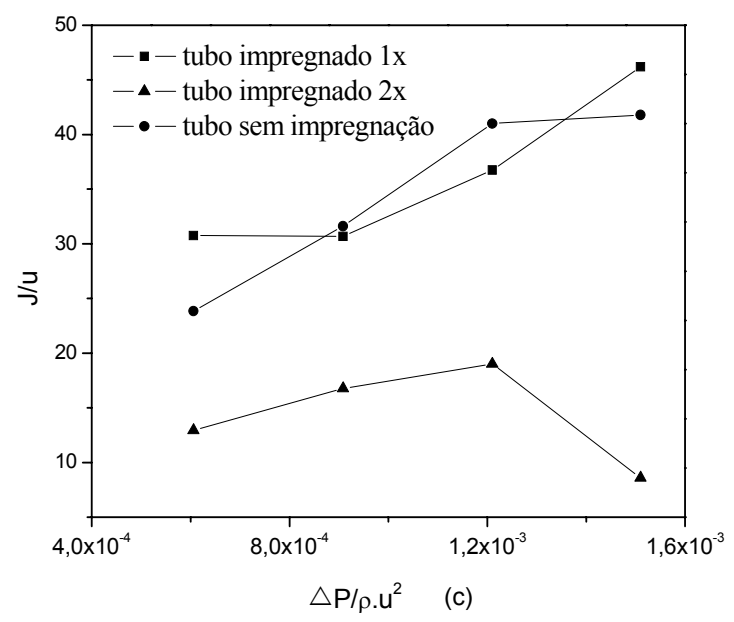

Figura 13. Gráfico dos valores adimensionais " $\mathrm{J} / \mathrm{u}$ " em função de " $\Delta \mathrm{P}_{\mathrm{tm}} / \rho . \mathrm{u}^{2}$ " para tubos com tamanho de poro de $0,5 \mu \mathrm{m}$, impregnados uma e duas vezes, queimados até $600^{\circ} \mathrm{C}$ e tubo sem impregnação para: Reynolds de 20335 a 22600 (a); Reynolds de 15609 a 16970 (b); Reynolds de 12602 a 13318 (c).

Observa-se na figura 13, que em todos os casos, os maiores fluxos foram alcançados para o tubo impregnado uma vez, durante a maior parte do intervalo de $\Delta \mathrm{P}_{\mathrm{tm}} /$ p.u $\mathrm{u}^{2}$. Por outro lado, observa-se que para o tubo impregnado duas vezes, conseqüentemente com uma maior concentração de zircônia, não apresentaram os maiores valores de fluxo. A esse respeito, pode-se dizer que a concentração de zircônia impregnada nos tubos cerâmicos influenciou no valor do fluxo adimensional, devido a interações de superfície (tensão superficial e interfacial) entre a emulsão (óleo/água) e o meio micro poroso modificado quimicamente.

As variações nos parâmetros fluidodinâmicos do processo (velocidade média e pressão trans-membrana) influenciaram o fluxo adimensional de forma significativa, proporcionando o seu aumento na maior parte do processo para os três primeiros casos.

Já na figura 14 é possível observar que, os maiores valores do fluxo adimensional são obtidos para os tubos cerâmicos impregnados uma vez e calcinados a $900^{\circ} \mathrm{C}$ (figuras 14 (a) e (c)).

Esse aumento no fluxo adimensional mostra que o fator temperatura de calcinação, causa influência no valor adimensional do fluxo e também em parâmetros fluidodinâmicos do processo, já que para um valor intermediário do Reynolds (figura 14 (b)), o tubo queimado até $900^{\circ} \mathrm{C}$ não apresentou os maiores valores de fluxo. $\mathrm{O}$ fator da concentração de zircônia impregnada, como no caso anterior (figura 13), também 
interferiu nos valores adimensionais do fluxo, que foram os menores em todos os gráficos (figura 14).
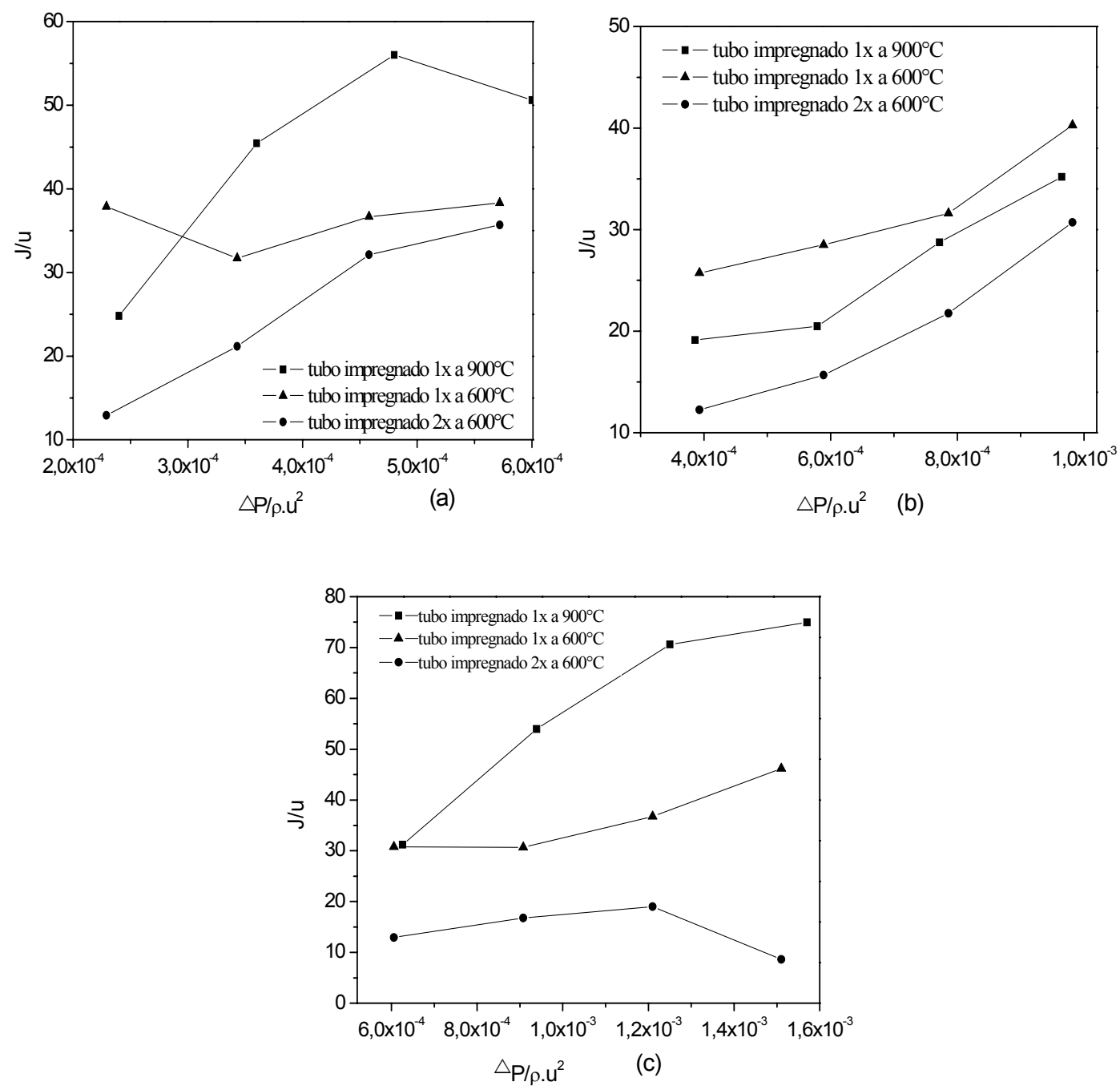

Figura 14. Gráfico entre os parâmetros adimensionais " $\mathrm{J} / \mathrm{u}$ " em função de " $\Delta \mathrm{P}_{\mathrm{tm}} / \rho \cdot \mathrm{u}^{2 "}$ p para tubos cerâmicos com tamanho de poro de $0,5 \mu \mathrm{m}$, impregnados em concentrações diferentes, queimados até $600^{\circ} \mathrm{C}$ e $900^{\circ} \mathrm{C}$ e tubo sem impregnação para: Reynolds de 20335 a 22600 (a); Reynolds de 15609 a 16970 (b); Reynolds de 12602 a 13318 (c).

A figura 15 apresenta os adimensionais para os experimentos realizados com um tubo cerâmico micro poroso impregnado uma vez com a solução de citrato de zircônio mais concentrada $(2,07 \%)$, com temperaturas de queima até $600^{\circ} \mathrm{C}$ e na seqüência até $900^{\circ} \mathrm{C}$. O processo foi investigado a $25^{\circ} \mathrm{C}$, com variação de pressão e velocidade tangencial. Os valores de Reynolds obtidos para os experimentos realizados com esse tubo foram: $\mathrm{Re}=16594$ e $\mathrm{Re}=19094$; para temperaturas de queima de até $600^{\circ} \mathrm{C}$ e 
$900^{\circ} \mathrm{C}$, respectivamente. Os valores adimensionais mostrados abaixo correspondem às vazões finais do processo para cada pressão trans-membrana (2, 3, 4 e 5 bar).

Observa-se na figura 15 que os valores do fluxo adimensional são bem maiores para o experimento realizado com o tubo queimado até $900^{\circ} \mathrm{C}$, comprovando que a temperatura de calcinação após impregnação nos tubos, influenciou nos parâmetros fluidodinâmicos do processo.

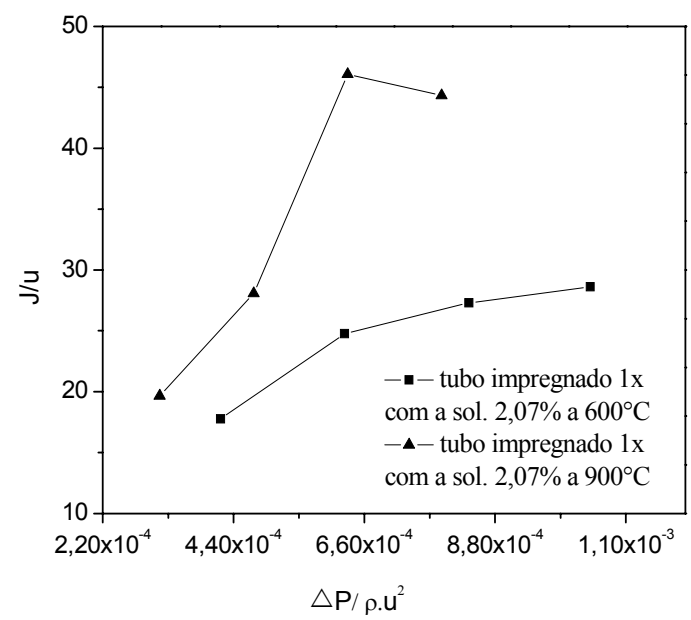

Figura 15. Resultados adimensionais do processo dinâmico. Tubo cerâmico com tamanho de poro de 0,5 $\mu \mathrm{m}$, impregnado com solução mais concentrada, com temperatura de calcinação até $600^{\circ} \mathrm{C}$ e $900^{\circ} \mathrm{C}$.

A figura 16 apresenta os adimensionais para os experimentos realizados com os tubos impregnados uma e duas vezes e ambos queimados até 600 e $900^{\circ} \mathrm{C}$. Estes experimentos foram conduzidos de forma estacionária, ou seja; em cada experimento, pressão trans-membrana e velocidade tangencial foram mantidos constantes. Os valores adimensionais apresentados são para os experimentos conduzidos a pressões de 2, 3, e 4 bar e por 45 minutos (correspondente à vazão final de cada processo). Os valores de Reynolds encontrados para os experimentos realizados com esses tubos, foram todos de aproximadamente 20000 .

A figura 16 mostra que os valores adimensionais de fluxo para os experimentos realizados com tubos cerâmicos impregnados e calcinados a $900^{\circ} \mathrm{C}$ superam os valores adimensionais do fluxo para os tubos impregnados a $600^{\circ} \mathrm{C}$. Pode-se dizer também que a concentração de zircônia impregnada tem influência nos resultados obtidos, pois os 
maiores valores do fluxo são alcançados para os tubos impregnados em uma menor concentração (tubo impregnado uma vez) de zircônia (figura 16 (a)).
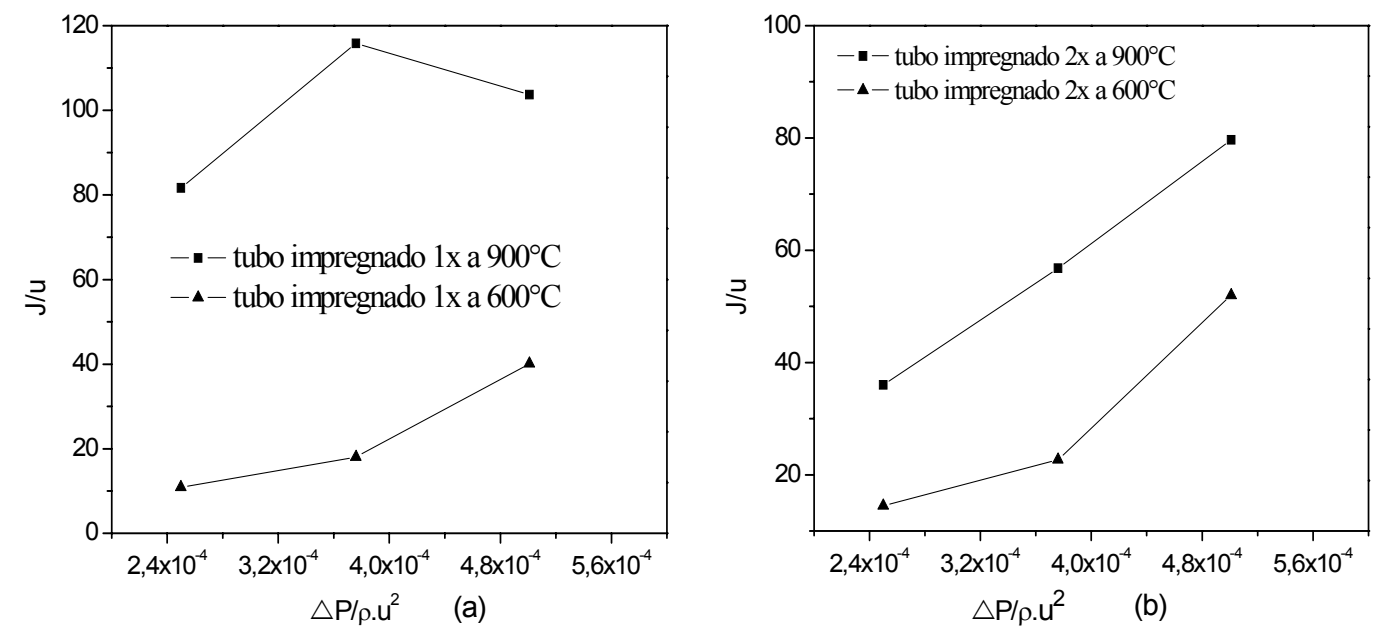

Figura 16. Tubos cerâmicos com tamanho de poro de $0,5 \mu \mathrm{m}$, impregnados em concentrações diferentes com temperatura de calcinação até $600^{\circ} \mathrm{C}$ e $900^{\circ} \mathrm{C}$. Parâmetros adimensionais em processo estacionário.

Nos dois casos (figura 16 (a) e (b)), os maiores fluxos são obtidos para a maior pressão trans-membrana (4 bar); exceto na figura 16 (a), onde o valor adimensional tem uma pequena queda, onde talvez haja uma tendência ao entupimento no meio ou na superfície cerâmica do tubo. Koltuniewicz et al (1995), relataram em seu trabalho que o efeito da pressão trans-membrana pode influenciar na queda do fluxo tangencial após 150 min de operação, mesmo a altas pressões, devido a essa tendência.

Os gráficos a seguir ilustram os resultados obtidos para o adimensional de Sherwood, $\mathrm{Sh}=\mathrm{k} . \mathrm{d} / \mathrm{D}$ em função do adimensional de Reynolds. O número de Sherwood pode ser definido como uma medida adimensional da razão de transferência de massa convectiva, k, por transferência de massa difusiva ou molecular, D (CHERYAN, 1998). Para o cálculo do número de Sherwood, foi preciso primeiro calcular a taxa de concentração do meio fluido ou mistura emulsificada $\left(\mathrm{C}_{\mathrm{b}}\right.$ ou $\left.\mathrm{M}_{2}\right)$, parâmetro selecionado para intervalos de tempo correspondente aos 15, 20 e 30 min de processo, para cada variação de pressão trans-membrana $(2,3,4$ e 5 bar). Esse cálculo foi feito através da fórmula:

$$
\mathrm{M}_{1} \cdot \mathrm{V}_{1}=\mathrm{M}_{2} \cdot \mathrm{V}_{2}
$$

sendo: 
$\mathrm{M}_{1}=$ concentração inicial do meio fluido (mistura) $=1 \%$.

$\mathrm{V}_{1}=$ volume inicial da mistura no tanque de alimentação.

$\mathrm{M}_{2}=$ concentração da mistura após a retirada de volume do permeado aos 15, 20 e 30 min de processo (considerando rejeição de óleo 100\%).

$\mathrm{V}_{2}=$ volume final da mistura após a retirada de volume do permeado (ou fluxo trans-membrana) para os 15, 20 e 30 min de processo $\left(\mathrm{V}_{1}\right.$ - volume retirado).

Após esse procedimento, foi calculado o valor do coeficiente global de transferência de massa $(k)$ a partir da equação diferencial de transporte para conservação das espécies dentro do tubo, desprezando o termo de difusão axial e integrada para toda seção transversal do tubo.

O procedimento dado na literatura considera que a rejeição das espécies em solução é $100 \%$, conduzindo a seguinte relação entre a concentração do meio fluido, $\mathrm{C}_{\mathrm{b}}$ e a concentração (inicial) na entrada do tubo, $\mathrm{C}_{0}: \mathrm{C}_{\mathrm{b}}(L) / \mathrm{C}_{0}=\exp (-2 . L . k / R . u)(\mathrm{DEEN}$, 1998 e FONTES, 2005), sendo que " $k$ " é o coeficiente global de transferência de massa; $L$, o comprimento do tubo; $R$, raio interno do tubo e $u$, velocidade média. O $k$ é uma medida da mobilidade do soluto, neste caso gotículas de óleo, devido ao movimento forçado e convectivo gerado pela corrente principal no sistema. Análogo ao coeficiente de transferência de calor (h), o " $k$ " é medido como a razão do fluxo de massa pela força motriz.

Em ultra-filtração, a força motriz é a diferença na concentração do soluto na superfície da membrana e em alguns pontos arbitrariamente definidos na extensão do fluido (CHERYAN, 1998).

O coeficiente de difusividade foi calculado conforme a literatura (CHERYAN, 1998), através da equação de Wilke-Chang:

$$
\mathrm{D}_{\mathrm{AB}}=\frac{\left(117,3 \cdot 10^{-18}\right)\left(\phi \cdot M_{B}\right)^{0,5} T}{\mu \cdot V_{A}^{0,6}}
$$

sendo:

$D_{A B}=$ difusividade do componente A no solvente $\mathrm{B}, \mathrm{m}^{2} / \mathrm{s}$

$M_{B}=$ peso molecular do solvente, $\mathrm{kg} / \mathrm{mol}=18$ para água

$T=$ temperatura, ${ }^{\circ} \mathrm{K}$

$\mu=$ viscosidade da solução, $\mathrm{kg} / \mathrm{m} . \mathrm{s}$ 
$V_{A}=$ volume molar do soluto no ponto de ebulição normal, $\mathrm{m}^{3} / \mathrm{kmol}$

$\phi=$ constante de associação para o solvente $=2,26$ para água.

Com base nos valores do peso molecular e densidade do soluto (óleo de girassol) retirado da literatura (HOTRUM, 2004), o valor do volume molar do soluto $\left(V_{A}\right)$ foi encontrado. O valor da viscosidade da solução foi medido no reômetro LDVIII+ da Brookfield $\left(1,1 \times 10^{-3} \mathrm{~Pa} \mathrm{~s}\right)$ e o valor da temperatura foi de $25^{\circ} \mathrm{C}$ ou $298 \mathrm{~K}$. $\mathrm{O}$ valor calculado através da Equação (6) para a difusividade foi de $1,33 \times 10^{-11} \mathrm{~m}^{2} / \mathrm{s}$.

De acordo com a literatura (KINUGASA e WATANABE, 1996), valores para a difusividade da amônia $\left(\mathrm{NH}_{3}\right)$ na fase aquosa e na membrana, foram estimados em função da concentração de surfactante (como um filme adsorvido na interface óleo-água de uma emulsão), através de vários modelos descritos por diferentes autores. No presente trabalho não houve uso de surfactantes, por isso, fez-se uma aproximação para concentrações nulas de surfactante. Assim, foi possível estimar um valor para a difusividade: $5,5 \times 10^{-11} \mathrm{~m}^{2} / \mathrm{s}$. Comparado ao valor calculado pela Equação de WilkeChang, pode-se dizer que não houve alteração entre os valores quanto à ordem de grandeza. Assim, o valor calculado para a emulsão em estudo foi utilizado. Com base neste valor e nos valores de " $k$ " calculados para tempos variando de $t=0$ a $t=15$ min; $t$ $=15 \mathrm{at}=30 \mathrm{~min}$ e $\mathrm{t}=30 \mathrm{at}=45 \mathrm{~min}$, em quatro pressões trans-membrana $(2,3,4$ e 5 bar) e três valores de Reynolds, pôde-se encontrar respectivamente os valores de Sherwood.

Os fundamentos do mecanismo de transferência de massa estão vinculados à formação das camadas limites de velocidade e concentração (ZEMAN e ZYDNEY, 1996). O coeficiente " $k$ " depende de diversas grandezas que são propriedades do fluido e do escoamento, conduzindo a uma correlação geral da forma: $\mathrm{Sh}=\mathrm{A} \cdot(\mathrm{Re})^{\alpha}$. $(\mathrm{Sc})^{\beta}$. A constante "A" geralmente reflete variações das propriedades físicas e outras condições do sistema, que não pode considerar todas as interações e propriedades do processo.

As figuras a seguir apresentam os valores do número adimensional de Sherwood em função do número de Reynolds, para regime de escoamento turbulento, pois o número de Reynolds foi maior que 4000 em todos os experimentos realizados. A figura 17 ilustra os valores de "Sh" correspondente aos valores médios do processo para $u=$ 3,$16 ; 2,37$ e $1,86 \mathrm{~m} / \mathrm{s}$ e pressões trans-membrana: $2,3,4$ e 5 bar; respectivos ao tubo impregnado uma vez a $600^{\circ} \mathrm{C}$. 
Para comparação com correlação da literatura, selecionou-se a correlação de Deissler, $S h=0,023(R e)^{0,875}$. $(S c)^{0,25}$ (ZEMAN e ZYDNEY, 1998), de onde foram obtidos valores baseados na viscosidade: $\mu=1,1 \times 10^{-3}$ Pa s e densidade: $\rho=997 \mathrm{~kg} / \mathrm{m}^{3}$ da mistura; $R e=22600,16970$ e 13318 e $S c=\mu / \rho . D=8,3 \times 10^{4}$; em que D é a difusividade do óleo em água, calculada através da Equação (6). Os resultados da literatura são também apresentados na figura 17.

Pode ser observado na figura 17 um comportamento semelhante entre os resultados dos gráficos 17 (a), 17 (b) e 17 (c). Os maiores valores de Sherwood (nas quatro pressões estudadas) foram alcançados para valores de Reynolds próximos de 22000, na menor pressão trans-membrana (2 bar). Isto ocorre provavelmente devido à ação cisalhante num Reynolds elevado, que conduziu a uma diminuição da camada de polarização e consequentemente atingiu melhor desempenho na transferência de massa sem que fosse preciso pressões trans-membrana maiores.
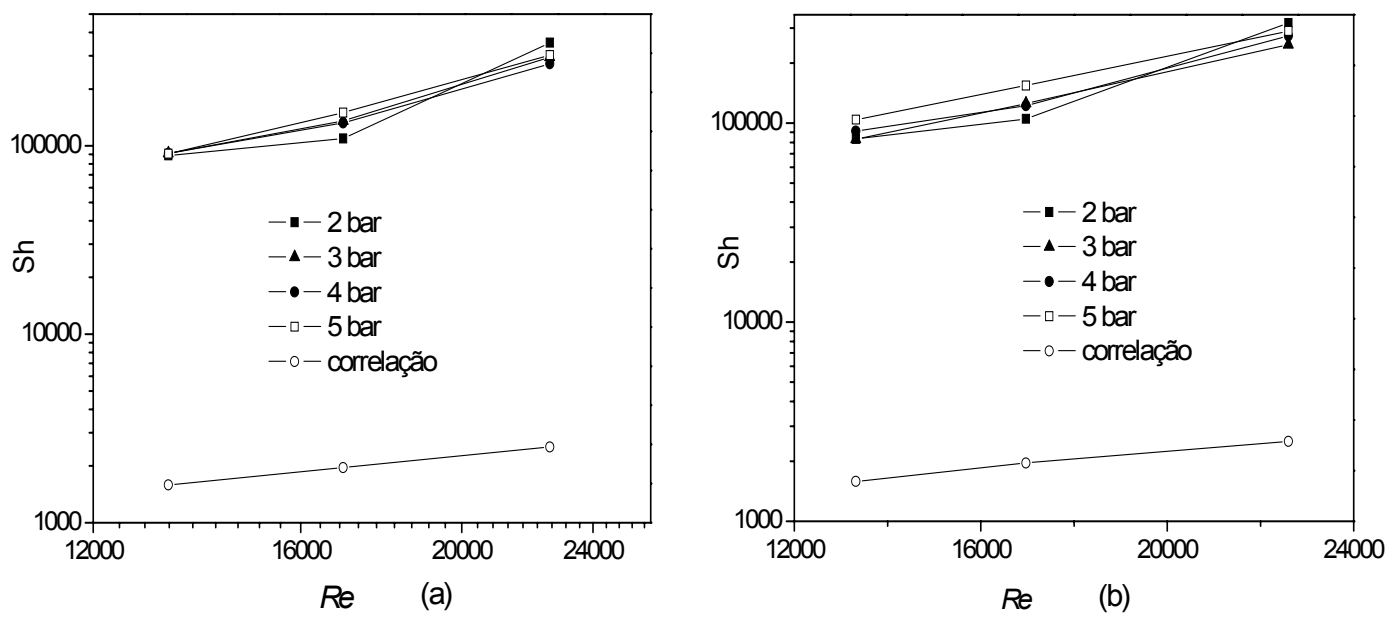


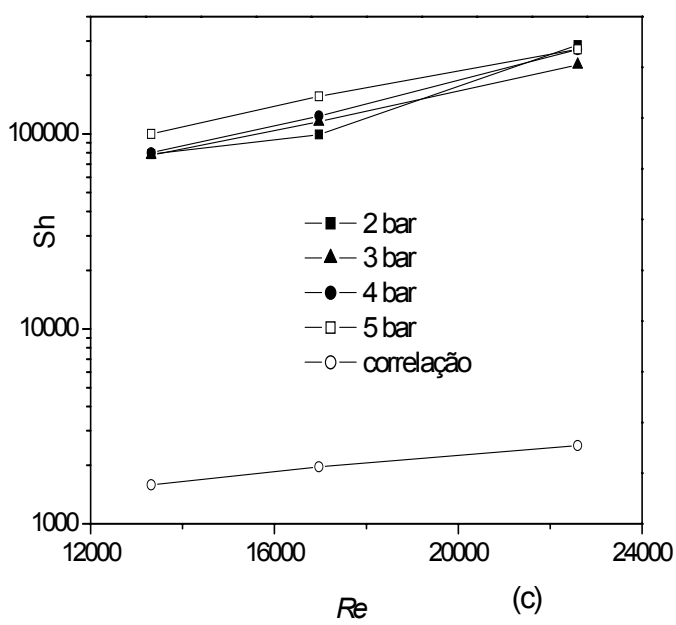

Figura 17. Tubo impregnado uma vez a $600^{\circ} \mathrm{C}$. Para $R e=22600,16970,13318$. Valores de Sherwood para: (a) $\mathrm{t}=0$ a $\mathrm{t}=15 \mathrm{~min}$; (b) $\mathrm{t}=15 \mathrm{at}=30 \mathrm{~min}$; (c) $\mathrm{t}=30 \mathrm{at}=45 \mathrm{~min}$. Comparação do adimensional de Sherwood (Sh) com a correlação de Deissler (ZEMAN e ZYDNEY, 1996).

Não houve também variações significativas nos valores de Sherwood da figura 17 (b) em comparação com a figura 17 (c), ou seja; neste intervalo de tempo (30 minutos finais do processo), o mecanismo de transferência de massa tornou-se praticamente estável em qualquer pressão trans-membrana.

Observa-se também que o aumento de velocidade (que conduz diretamente a maiores Reynolds), proporcionou maiores valores de Sherwood, devido ao efeito de cisalhamento, dado compatível com a literatura (ZEMAN e ZYDNEY, 1996).

Os valores de Sh para a correlação de Deissler, são muito menores do que os valores de Sh calculados para o coeficiente global de transporte de massa $(k)$. Por isso, o melhor ajuste aos resultados experimentais não foi obtido pela correlação, provavelmente devido ao comportamento particular da emulsão, que não é considerado de forma específica, mas de forma genérica nesta correlação.

A figura 18 ilustra os valores de Sherwood para os experimentos realizados com o tubo impregnado duas vezes, os valores médios do processo foram: $u=2,84 ; 2,29 \mathrm{e}$ $1,83 \mathrm{~m} / \mathrm{s}$; para pressões trans-membrana de 2, 3, 4 e 5 bar. Esses valores são comparados aos valores da correlação de Deissler, que foram calculados com base nos seguintes valores: $R e=20335 ; 16397$ e 13103; e $S c=8,3 \times 10^{4}$. 


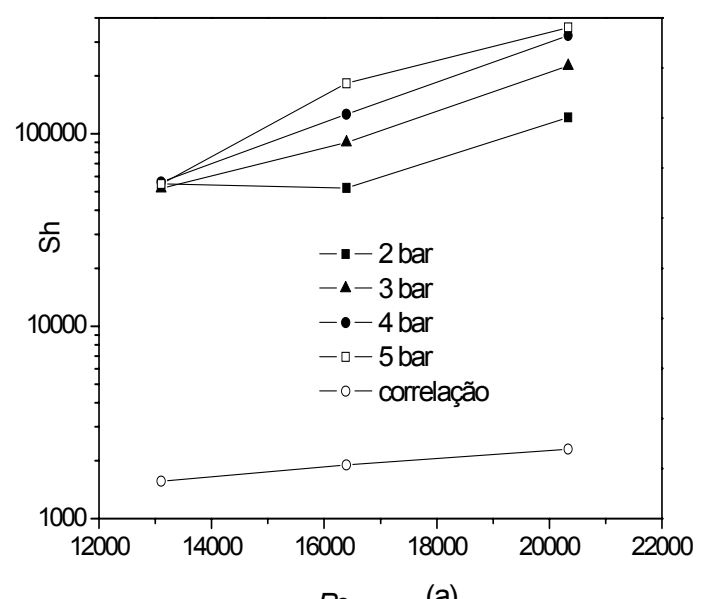

$\operatorname{Re} \quad(a)$

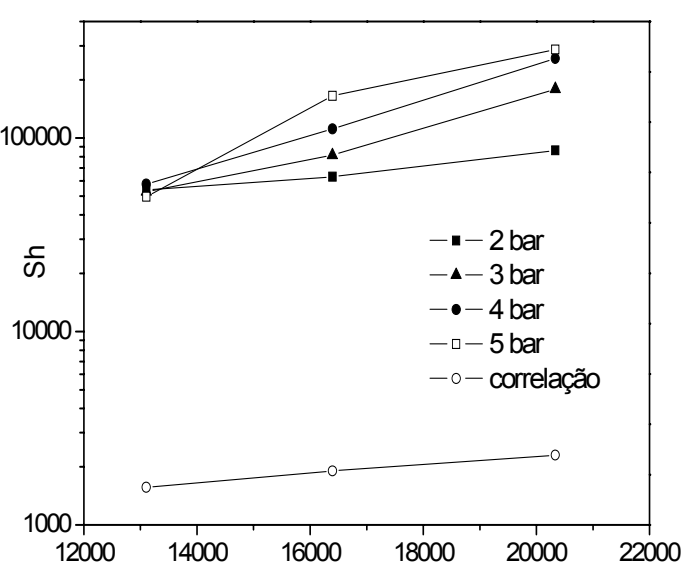

(b)

Figura 18. Tubo impregnado duas vez a $600^{\circ} \mathrm{C}$. Para $R e=20335,16397,13103$. Valores de Sherwood para: (a) $\mathrm{t}=0 \mathrm{at}=15 \mathrm{~min}$; (b) $\mathrm{t}=15 \mathrm{at}=30 \mathrm{~min}$. Adimensional de Sherwood.

$\mathrm{Na}$ figura 18 é observado um comportamento diferente da figura 17, os maiores valores de Sherwood são observados para os maiores Reynolds (próximo de 20000) na maior pressão trans-membrana (5 bar), nos dois casos (figura 18 (a) e (b)). Nota-se também que o "Sh" cresce progressivamente com o aumento de pressão em todos os Reynolds. Neste caso, pode-se dizer que o mecanismo de transferência de massa teve melhor desempenho com aumento de pressão e velocidade do fluxo, onde há estabilização da camada de polarização. Quanto aos valores de Sherwood obtidos para a correlação, mostraram-se também bem menores do que os obtidos através de " $k$ ", devido talvez à desconsideração de propriedades específicas da mistura ou emulsão e do mecanismo de transporte de massa.

A figura 19 representa os valores de Sherwood para os experimentos realizados com o tubo impregnado uma vez em comparação com valores obtidos através da correlação de Deissler, os valores médios do processo foram: $u=2,89 ; 2,28$ e 1,79 m/s; para pressões trans-membrana de 2, 3, 4 e 5 bar. 

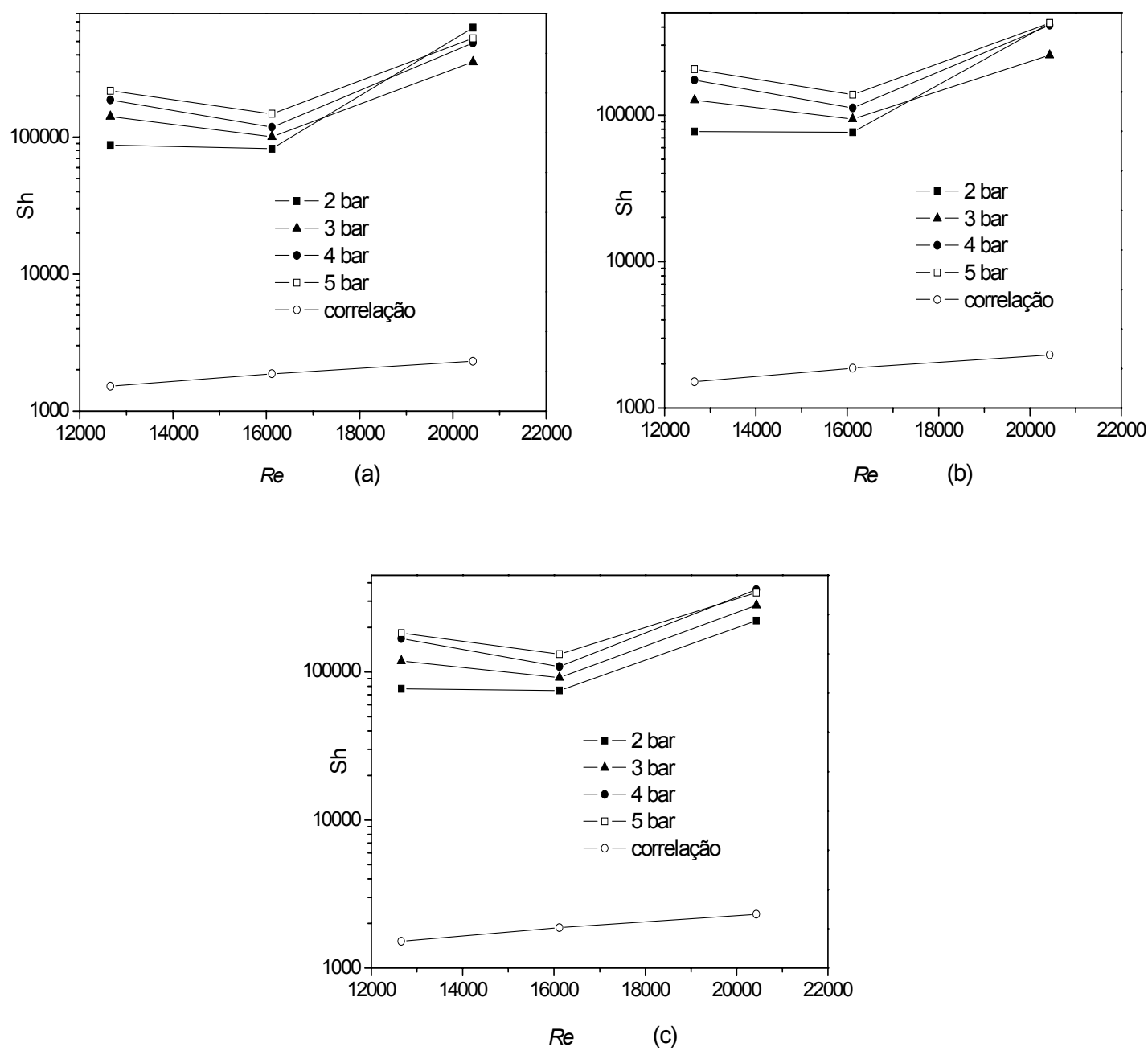

Figura 19. Tubo impregnado uma vez a $900^{\circ} \mathrm{C}$. Para $R e=20431,16119,12655$. Valores de Sherwood para: (a) $\mathrm{t}=0$ a $\mathrm{t}=15 \min$; (b) $\mathrm{t}=15 \mathrm{at}=30 \mathrm{~min}$; (c) $\mathrm{t}=30 \mathrm{a} \mathrm{t}=45 \mathrm{~min}$. Adimensional de Sherwood

Observa-se na figura 19 que assim como nos resultados anteriores, os maiores valores de Sh são alcançados para os maiores Reynolds (próximo de 20000) na maior pressão trans-membrana ( 5 bar), exceto na figura 19 (a) em que o maior Sh foi obtido na menor pressão ( 2 bar), provavelmente devido à ausência da camada gel polarizada no início do processo de separação, o que favorece o mecanismo de transporte de massa em baixa pressão. Os valores de Sh aumentam progressivamente com o aumento da pressão até Reynolds próximo de 16000 nos três gráficos, ou durante os 30 min do processo em cada pressão trans-membrana, acima desse Reynolds (16000), o processo assume um comportamento diferente.

Comparando os valores adimensionais de Sh para os três tubos impregnados (uma vez a $600^{\circ} \mathrm{C}$ e $900^{\circ} \mathrm{C}$ e duas vezes a $600^{\circ} \mathrm{C}$ ), é possível observar que o tubo 
impregnado uma vez a $900^{\circ} \mathrm{C}$, obteve os maiores valores de Sh, esse fato leva a crer que o parâmetro temperatura, após impregnação, teve influencia no transporte de massa durante o processo de separação, devido às propriedades físico-químicas características do meio filtrante. Os valores de Sh para a correlação mantêm-se baixos, como os resultados anteriores.

A figura 20 ilustra os valores de "Sh" para os experimentos realizados com o tubo sem impregnação em comparação com valores obtidos através da correlação de Deissler, os valores médios do processo foram: $u=3,14 ; 2,18$ e $1,76 \mathrm{~m} / \mathrm{s}$; para pressões trans-membrana de 2, 3, 4 e 5 bar.
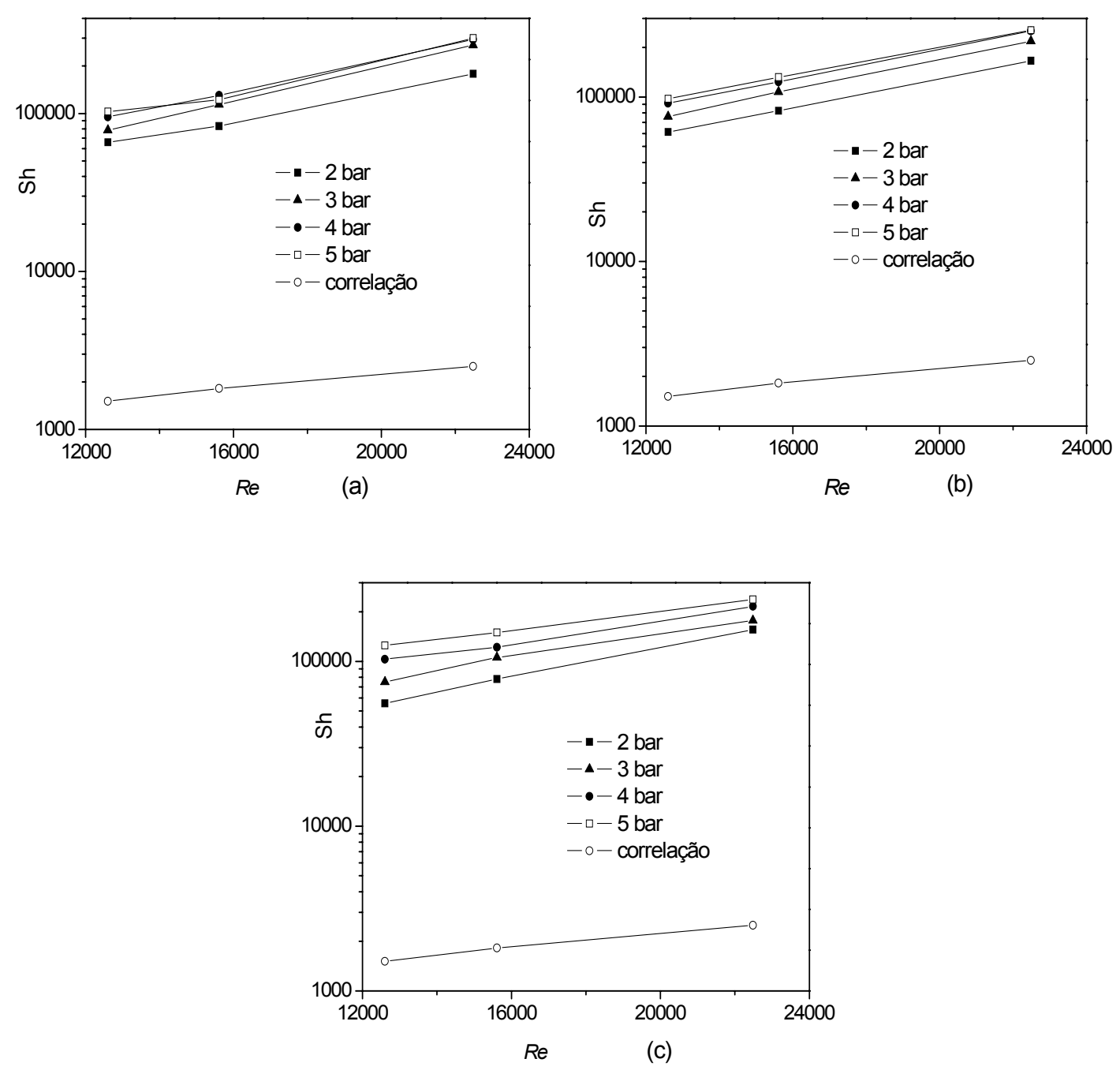

Figura 20. Tubo não impregnado. Para $R e=22483$, 15609, 12602. Valores de Sherwood para: (a) $\mathrm{t}=0 \mathrm{a}$ $\mathrm{t}=15 \mathrm{~min} ;(\mathrm{b}) \mathrm{t}=15 \mathrm{at}=30 \mathrm{~min} ;(\mathrm{c}) \mathrm{t}=30 \mathrm{at}=45 \mathrm{~min}$. Adimensional de Sherwood. 
A figura 20 mostra que os maiores valores de Sh são alcançados para Reynolds próximo de 22000 e na maior pressão trans-membrana (5 bar), mas mostraram-se menores em relação aos valores anteriores de $S h$. Isso evidencia que a zircônia impregnada na micro estrutura dos tubos pode influenciar no mecanismo de transporte de massa. Os valores de Sh para correlação de Deissler, também foram menores do que os calculados através do valor de $k$. A grande diferença entre os valores de Sherwood deste trabalho com os decorrentes da correlação de Deissler (apud ZEMAN \& ZYDNEY, 1996), é devido principalmente ao valor do coeficiente de difusividade (D). A obtenção da difusividade por correlações genéricas da literatura pode ser apenas uma estimativa, pois são restritas a fluidos particulares. O fenômeno físico neste processo de filtração não é decorrente apenas da polarização, mas também por causa da presença de zircônia no elemento filtrante

Um outro valor da difusividade pode ser estimado a partir dos próprios resultados do fluxo transmembrana do processo deste trabalho. Para isto, atribuímos como condição de contorno na superfície permeável, o fluxo transmembrana como sendo predominantemente difusivo e de acordo com o modelo de filme estagnado (ZEMAN \& ZYDNEY, 1996). Sendo assim o fluxo transmembrana é calculado como:

$$
\mathrm{J}=\left.\mathrm{D} \frac{\partial \mathrm{C}}{\partial \mathrm{r}}\right|_{\mathrm{r}=\mathrm{R}}
$$

em que o gradiente de concentração é calculado junto a superfície do tubo ( $\mathrm{r}=$ $\mathrm{R}$, onde "R" é o raio do tubo).

Da última equação a difusividade é calculada como:

$$
\mathrm{D}=\left.\int \frac{\partial \mathrm{C}}{\partial \mathrm{r}}\right|_{\mathrm{r}=\mathrm{R}}
$$

Para uma estimativa de " $\mathrm{D}$ ” a partir da equação (8), consideramos:

$$
\left.\frac{\partial \mathrm{c}}{\partial \mathrm{r}}\right|_{\mathrm{r}=\mathrm{R}} \approx \frac{\Delta \mathrm{c}}{\Delta \mathrm{r}}=\frac{\left(\mathrm{C}_{\mathrm{w}}-\mathrm{C}_{\mathrm{o}}\right)}{\delta}
$$

sendo que $\mathrm{C}_{\mathrm{w}}, \mathrm{C}_{\mathrm{o}}$ e $\delta$, são respectivamente a concentração na superfície do tubo permeável, a concentração da corrente principal ou da mistura original e a espessura da camada limite de concentração. A espessura da camada limite de concentração é aqui avaliada em ordem de grandeza, no valor de $\delta=0,1 \mathrm{~mm}$, valor que está de acordo com o 
trabalho de Paris et al. (2002). Como valor de $\mathrm{C}_{\mathrm{o}}$ consideramos o da mistura água/óleo, ou seja, $C_{o}=0,01 \mathrm{~kg} / \mathrm{l}$; como valor de $\mathrm{C}_{\mathrm{w}}$ consideramos no intervalo de $(10-90) . \mathrm{C}_{\mathrm{o}}$, onde apresentamos os resultados de " $D$ " para $C_{w}=10 . C_{o}$ e $C_{w}=90 . C_{o}$.

Para apresentar um resultado estimado de "D", seleciona-se um valor do fluxo transmembrana de um dos experimentos, como por exemplo, um valor da figura 10:

$$
\mathrm{J}=60 \mathrm{l} / \mathrm{h} \cdot \mathrm{m}^{2}=1,7 \cdot 10^{-5} \mathrm{~m} / \mathrm{s} \text {. }
$$

Considerando $C_{w}=10 . C_{0}$, encontramos para a difusividade o valor de $1,9.10^{-8}$ $\mathrm{m}^{2} / \mathrm{s}:$

$$
\mathrm{D}=\mathrm{J} /\left.\frac{\partial \mathrm{C}}{\partial \mathrm{r}}\right|_{\mathrm{r}=\mathrm{R}}=\frac{1,7.10^{-5}}{\frac{(10.0,01-0,01)}{0,1.10^{-3}}}=1,9.10^{-8} \mathrm{~m}^{2} / \mathrm{s}
$$

Considerando $C_{w}=90 . C_{0}$, encontramos para a difusividade o valor de $1,9.10^{-9}$ $\mathrm{m}^{2} / \mathrm{s}$ :

$$
\mathrm{D}=\quad \mathrm{J} /\left.\frac{\partial \mathrm{C}}{\partial \mathrm{r}}\right|_{\mathrm{r}=\mathrm{R}}=\frac{1,7 \cdot 10^{-5}}{\frac{(90.0,01-0,01)}{0,1.10^{-3}}}=1,9 \cdot 10^{-9} \mathrm{~m}^{2} / \mathrm{s}
$$

Revendo nos gráficos 4.8 a 4.12 os valores de Sherwood (Sh=k.d/D) deste trabalho, adotando por exemplo o valor de $\mathrm{D}=1,9.10^{-9} \mathrm{~m}^{2} / \mathrm{s}$, os resultados de Sherwood sofreram variação de pelo menos duas ordens de grandeza para menor, se aproximando dos valores da correlação de Deissler.

A seguir, serão apresentados os resultados da análise físico-química do processo de desemulsificação, através da análise de Teor de Carbono Orgânico Total (TOC), pH e condutividade do permeado coletado durante o processo. Os valores ilustrados através dos gráficos seguintes são respectivos aos experimentos descritos nas figuras 10 a 12 . A análise da qualidade do permeado em relação à concentração de carbono no processo dinâmico foi avaliada como mostra a figura 21, onde os valores de TOC são apresentados em função da pressão trans-membrana (2, 3, 4 e 5 bar) em relação aos valores de Reynolds obtidos em cada experimento (para cada tubo ensaiado). Os valores do Reynolds encontrados para os tubos impregnados uma vez a 600 e $900^{\circ} \mathrm{C}$, duas vezes a $600^{\circ} \mathrm{C}$ e sem impregnação foram em média: $R e=21806 ; 16325 ; 13008$.

Conforme mostra a figura 21 , os maiores valores de TOC foram encontrados com o tubo impregnado duas vezes, na maior pressão trans-membrana de operação, ou 
seja 5 bar. Observa-se também um comportamento típico para este mesmo tubo em todos os Reynolds; o valor de TOC tem um aumento abrupto a partir de 3 bar.
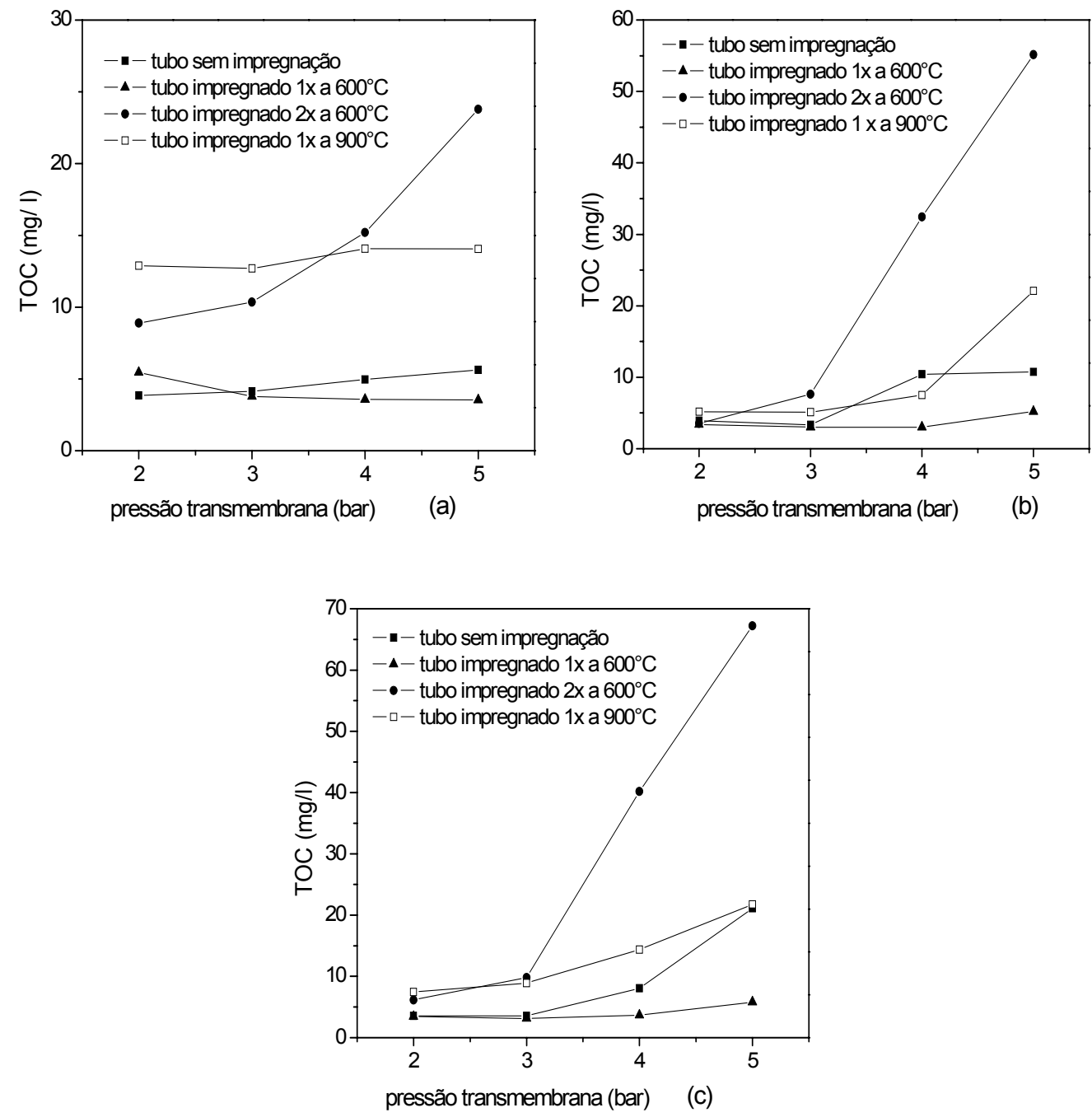

Figura 21. Análise do permeado. TOC (mg/l) em função da pressão trans-membrana (bar) para Reynolds: próximo de 20000 (a); próximo de 16000 (b); próximo de 12000 (c).

Pode-se dizer que, para uma maior concentração de zircônia impregnada na estrutura porosa, menor o desempenho na separação da mistura água-óleo ou na desemulsificação, principalmente em pressões trans-membrana maiores que 3 bar. Segundo Ting e Wu (1999), gotículas de óleo podem passar facilmente através da membrana se o tamanho de cada uma delas for menor do que o tamanho dos poros ou se a pressão do retentado exceder a pressão capilar (pressão dentro dos poros), desta forma 
a gotícula de óleo pode ser deformada e entrar pela estrutura da membrana. Como resultado, o óleo passa através da membrana, diminuindo o desempenho na separação.

Nesse caso, o meio filtrante apresentou um comportamento hidrofílico, ou seja; atrai a água e repele o óleo, por isso um teor de carbono mais alto em relação aos outros meios filtrantes. Mesmo o tubo impregnado duas vezes $\left(600^{\circ} \mathrm{C}\right)$ tendo apresentado altos teores de carbono em relação aos outros tubos, ainda assim houve um bom desempenho de rejeição no processo, pois a concentração de carbono no concentrado foi de 5040 $\mathrm{mg} / \mathrm{l}$, ou até 100 vezes maior do que a quantidade de carbono no permeado.

Percebe-se também que os menores valores de TOC são alcançados para o tubo impregnado uma vez, no maior Reynolds e para maior pressão trans-membrana ( 5 bar) (fiigura 21 (a)), isso porque talvez em maiores velocidades e pressões a ação do cisalhamento supere a resistência causada pela camada de polarização, juntamente com efeitos de superfície (tensão superfícial), devido à presença de zircônia, permitindo assim um bom desempenho na separação; e nesse caso o meio filtrante pode ser considerado hidrofóbico (repele a água e atrai o óleo), devido ao baixo teor de carbono encontrado no permeado.

A figura 22 apresenta os resultados do TOC em função da pressão transmembrana (2, 3 e 4 bar) para os tubos impregnados uma vez a 600 e $900^{\circ} \mathrm{C}$ e duas vezes a $600^{\circ} \mathrm{C}$ para a série estática, ou seja; cada experimento realizado a uma pressão diferente e em uma única velocidade de fluxo. A figura 22 (b) apresenta os resultados de TOC em função da pressão trans-membrana (2, 3, 4 e 5 bar), para os experimentos realizados com os tubos impregnados uma vez a 600 e $900^{\circ} \mathrm{C}$ com a solução mais concentrada e com a membrana comercial de tamanho de poro de $0,6 \mu \mathrm{m}$.

Na figura 22 (a), é possível observar um comportamento semelhante tanto para os tubos impregnados uma vez como para os tubos impregnados duas vezes. Os tubos impregnados duas vezes apresentam maiores valores de TOC em relação aos tubos impregnados uma vez, e apresentam maior TOC na menor pressão trans-membrana (2 bar); ao contrário dos tubos impregnados uma vez, que apresentam menor TOC na menor pressão trans-membrana. 

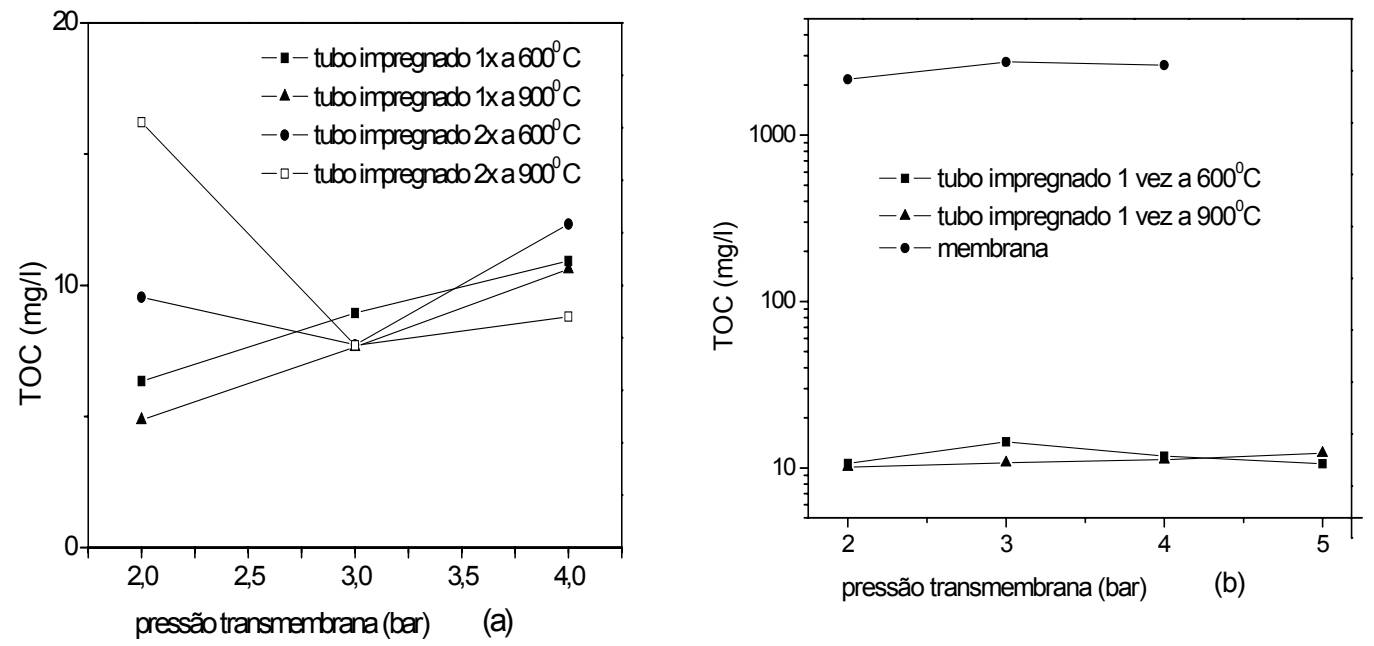

Figura 22. Análise do permeado. TOC (mg/l) em função da pressão trans-membrana (bar) para processo estático (a); dinâmico (b).

O tubo impregnado uma vez a $900^{\circ} \mathrm{C}$ foi o que apresentou melhor resultado (menor teor de carbono no permeado) em relação aos outros tubos, provavelmente devido a propriedades estruturais da zircônia impregnada, que podem mudar com o aumento da temperatura de calcinação após a impregnação. Uma possível mudança na estrutura cristalina da zircônia pode ter influenciado no desempenho da separação. A figura 22 (b) mostra que os valores do TOC para os tubos impregnados foram muito menores do que os valores obtidos para a membrana comercial com tamanho de poros de $0,6 \mu \mathrm{m}$.

Embora a membrana apresente um bom desempenho no processo de microfiltração (altos valores de fluxo trans-membrana), como mostra a figura 23, mostrou-se ineficiente quanto à separação.

Deduz-se então, que a membrana poderia apresentar melhores resultados para este processo, se a estrutura da membrana tivesse tamanho de poros bem menor que 0,6 $\mu \mathrm{m}$ e o processo fosse conduzido a baixas pressões trans-membrana. Neste caso o processo com membrana seria conduzido na faixa de ultra filtração, consequentemente o fluxo trans-membrana sofreria uma significativa redução. 


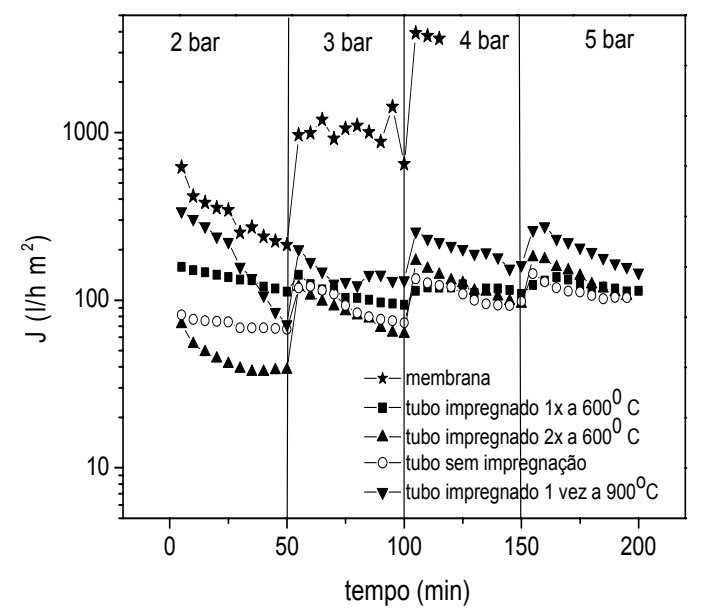

Figura 23. Fluxo trans-membrana nas pressões trans-membrana: 2, 3, 4 e 5 bar para Reynolds próximo de 20000.

A discussão a seguir, a partir da figura 24 , demonstra as medidas físico-químicas ( $\mathrm{pH}$ e condutividade elétrica) em relação ao permeado retido durante os experimentos realizados para o processo dinâmico. Observa-se nos gráficos da figura 24, que os maiores valores de $\mathrm{pH}$ (próximos de 7,00) foram alcançados para as maiores velocidades (Reynolds próximo de 22000) na maior parte do processo, e correspondem aos valores de TOC da figura 21 (a), que mostra também os menores valores de teor de carbono, ou seja; um filtrado praticamente isento de óleo, e próximo ao valor de TOC da água de torneira $(9,50 \mathrm{mg} / \mathrm{l})$. Exceto para figura 24 (b), onde os maiores valores de $\mathrm{pH}$ correspondem a um Reynolds de valor intermediário.

Os menores valores de $\mathrm{pH}$ foram obtidos para menores velocidades (Reynolds próximo de 12000) e correspondem aos maiores valores de TOC da figura 21 (b) e (c), pois uma maior quantidade de carbono no filtrado, implica numa maior quantidade de óleo que não ficou retido e provavelmente isso causa a diminuição no $\mathrm{pH}$, principalmente devido à acidez relativa do óleo, por causa da presença de ácidos graxos (como: ácido linoleico e lenolênico). 

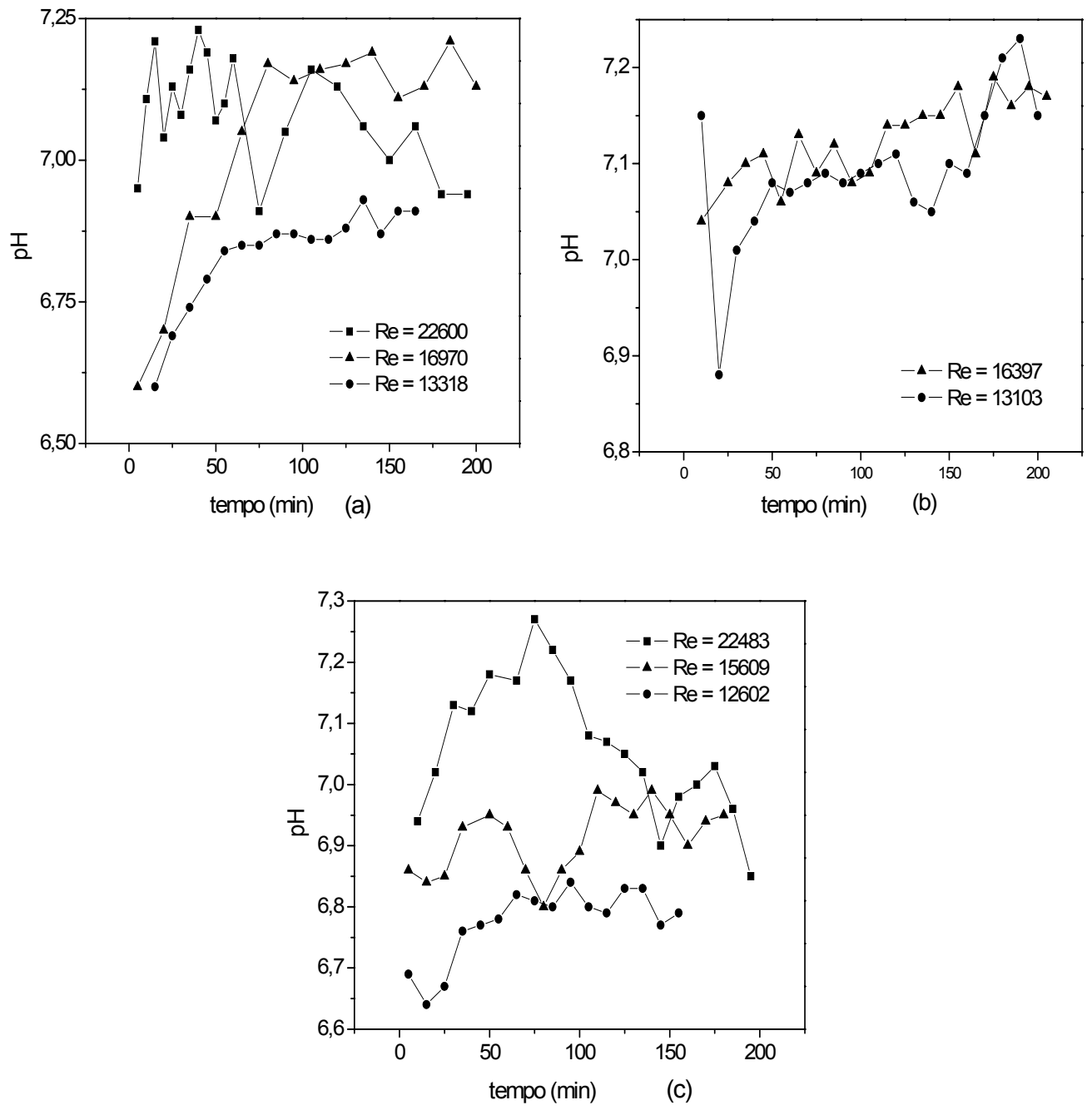

Figura 24. Valores de pH em função do tempo do processo, em diferentes Reynolds e pressões transmembrana (2, 3, 4 e 5 bar). Para tubo impregnado 1 vez a $600^{\circ} \mathrm{C}$ (a); tubo impregnado 2 vezes a $600^{\circ} \mathrm{C}$ (b); tubo sem impregnação (c).

Os menores valores de $\mathrm{pH}$ foram obtidos para menores velocidades (Reynolds próximo de 12000) e correspondem aos maiores valores de TOC da figura 21 (b) e (c), pois uma maior quantidade de carbono no filtrado, implica numa maior quantidade de óleo que não ficou retido e provavelmente isso causa a diminuição no $\mathrm{pH}$, principalmente devido à acidez relativa do óleo, por causa da presença de ácidos graxos (como: ácido linoleico e lenolênico).

A figura 25 ilustra os resultados obtidos das medidas de condutividade elétrica como função do tempo de processo de micro filtração das misturas de água-óleo de girassol com os tubos impregnados e queimados a $600^{\circ} \mathrm{C}$ e sem impregnação. A condutividade elétrica é a capacidade que a água possui de conduzir corrente elétrica. 
Este parâmetro está relacionado com a presença de íons dissolvidos na água, que são partículas carregadas eletricamente. Quanto maior for a quantidade de íons dissolvidos, maior será a condutividade elétrica da água.

Os valores de condutividade do filtrado em relação ao tempo do processo, são maiores na maior velocidade ou maior Reynolds (figura 25 (a)) e as amostras de permeado do tubo impregnado duas vezes, apresentaram os maiores valores de condutividade na maior parte do processo, exceto no maior Reynolds, onde o tubo impregnado uma vez obteve maiores valores.

O tubo impregnado duas vezes apresenta um comportamento diferente dos outros, o valor da condutividade varia durante todo o processo de filtração. Esse aumento na condutividade elétrica (para o tubo impregnado 2 vezes), pode ser comparado ao aumento no valor do TOC para o mesmo tubo (figura 21), pois um aumento do teor de carbono no permeado (devido ao óleo não retido) pode ter elevado a presença de íons dissolvidos na água, elevando a condutividade elétrica no permeado.
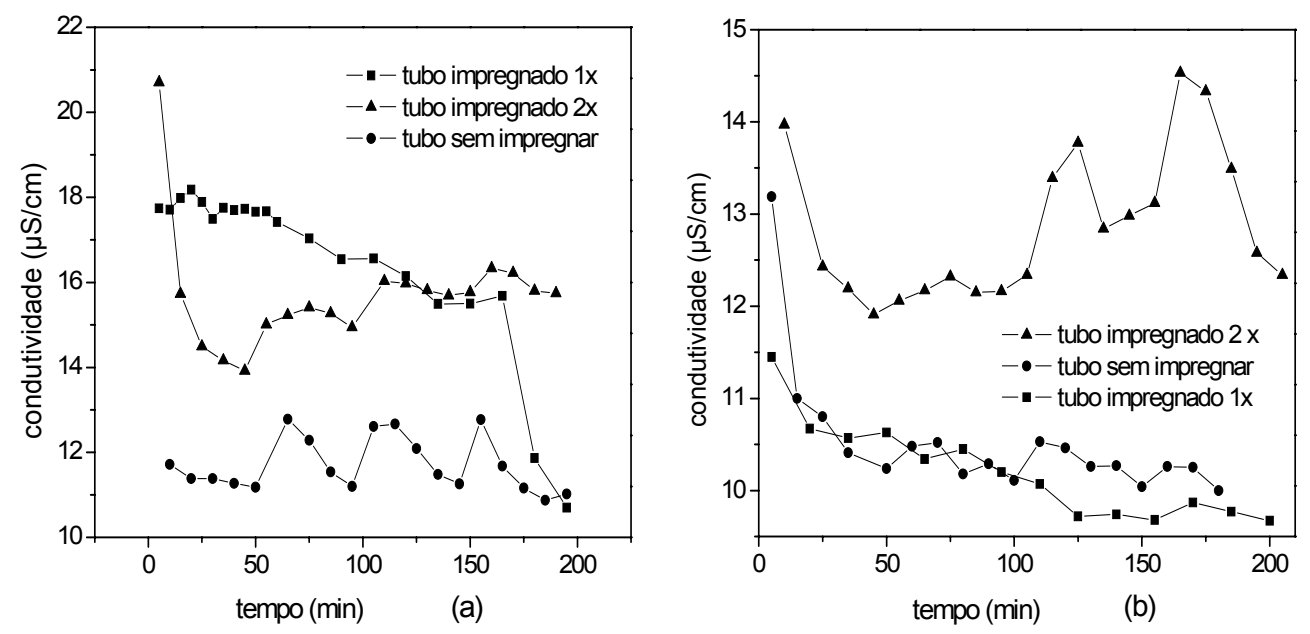


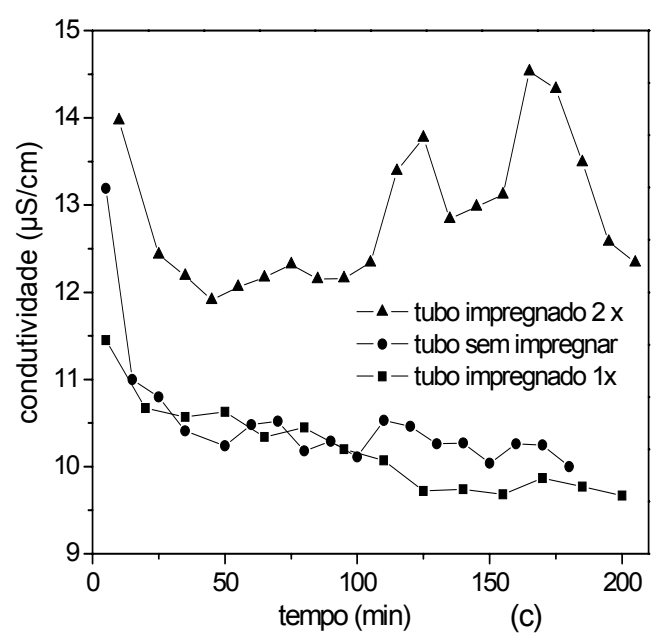

Figura 25. Condutividade elétrica em função do tempo do processo em diferentes pressões transmembrana (2, 3, 4 e 5 bar) e para Reynolds acima de 20000 (a); acima de 16000 (b); acima de 12000 (c). Processo dinâmico.

Comparando os valores obtidos experimentalmente com o valor medido para a água de torneira (usada na mistura), que foi de $36 \mu \mathrm{S} / \mathrm{cm}$, este valor supera todos os valores de condutividade elétrica medidos para os permeados, talvez devido a interações físico-químicas entre íons presentes nesta água e a superfície cerâmica (composta de muitos elementos químicos como, alumínio, zircônio, magnésio, silício, etc.) que influenciam na concentração de íons ou sais na água permeada. Ainda assim, o filtrado pode ser considerado como uma água de boa qualidade, não para reuso humano, mas com outras finalidades como no uso industrial e irrigação.

\subsection{Caracterização da Micro Estrutura Cerâmica Impregnada}

O Microscópio Eletrônico de Varredura (MEV) é um equipamento versátil que permite a obtenção de informações estruturais e químicas de amostras diversas. Um feixe fino de elétrons de alta energia incide na superfície da amostra onde, ocorrendo uma interação, parte do feixe é refletida e coletada por um detector que converte este sinal em imagem de BSE (ou ERE) - imagem de elétrons retroespalhados - ou nesta interação a amostra emite elétrons produzindo a chamada imagem de ES (elétrons secundários). Ocorre também a emissão de raios-X que fornece a composição química 
elementar de um ponto ou região da superfície, possibilitando a identificação de alguns elementos presentes.

Neste trabalho, a técnica de microscopia eletrônica de varredura (MEV), foi usada para estudar a morfologia do material tratado e não tratado quimicamente e obter o mapeamento de zircônio nas amostras (para constatar a presença de zircônia). Para identificar a composição química da estrutura microporosa tubular, foi realizada a emissão de raios-X sobre as amostras (EDX). O aparelho ZEISS - modelo DSM 940A foi usado nesta análise.

As micrografias abaixo ilustram a análise morfológica (imagem da parte interna cortada e mapeamento respectivo da imagem) e composição química qualitativa da estrutura micro porosa com e sem impregnação química em diferentes concentrações e diferentes temperaturas para tratamento térmico (pós-impregnação), através da técnica de microscopia eletrônica de varredura (MEV), para estudo da morfologia e emissão de raios-X sobre as amostras, como uma análise elementar qualitativa. A figura 26 apresenta a morfologia do material cerâmico micro poroso impregnado uma e duas vezes e queimado a $600^{\circ} \mathrm{C}$, através de imagens ampliadas $5000 \mathrm{x}$ e seus respectivos mapeamentos.

A figura 26 (a) e (b) mostra a imagem ampliada da superfície do material cerâmico impregnado uma vez e queimado a $600^{\circ} \mathrm{C}$ e o mapeamento de zircônio, respectivamente. É possível observar na figura 26 (a), que houve a formação de alguns aglomerados de nano partículas de zircônia na micro estrutura porosa, resultado do processo de impregnação e queima, em que pode ter ocorrido o crescimento de grãos de zircônia durante o tratamento térmico que o tubo foi submetido. A figura 26 (b) ilustra o mapeamento de zircônio, os pontos em amarelo distribuídos por toda a superfície, indicam a presença deste elemento e, portanto, de zircônia (óxido) espalhada de maneira mais uniforme pela micro estrutura, além dos aglomerados. 


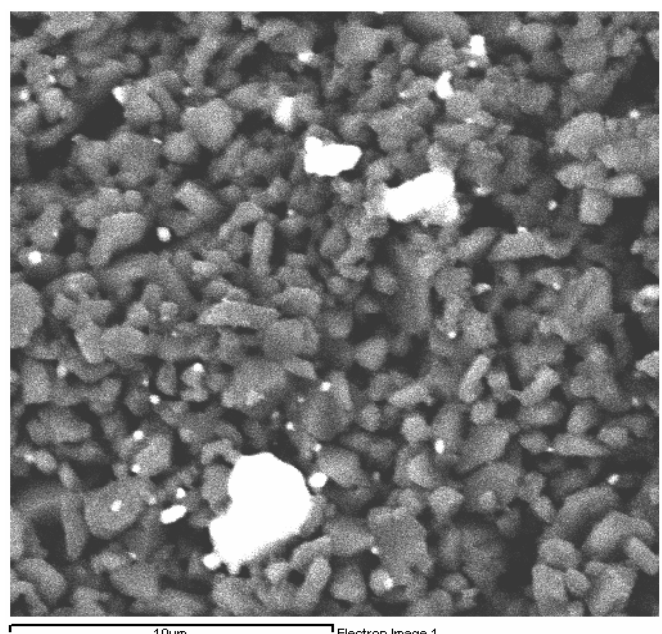

(a)

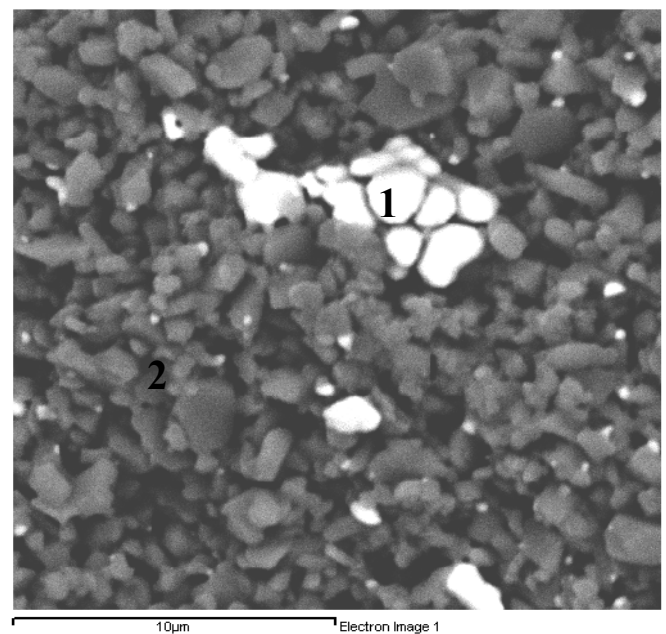

(c)

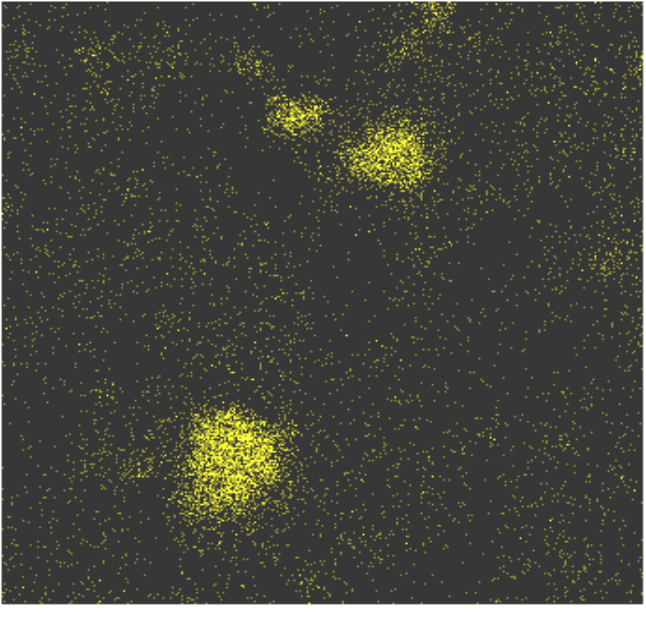

(b)

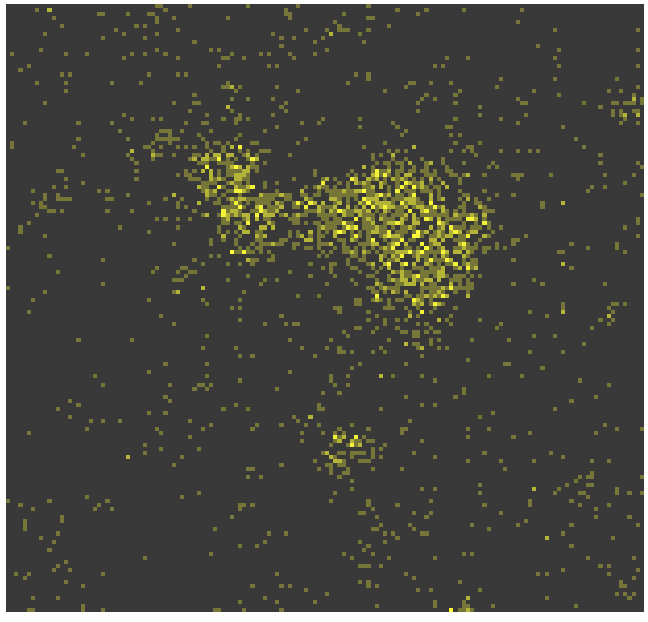

(d)

Figura 26. Análise morfológica do material cerâmico tubular impregnado: tubo impregnado 1 vez (a) e respectivo mapeamento (b); tubo impregnado 2 vezes (c) e respectivo mapeamento (d).

Da mesma forma, a figura 26 (c) e (d), representam a imagem ampliada da micro estrutura impregnada duas vezes e queimada a $600^{\circ} \mathrm{C}$ e o mapeamento de zircônio, respectivamente. Na figura 26 (c), observa-se também a formação de aglomerados de nano partículas de zircônia na estrutura micro porosa, a figura ao lado mostra o mapeamento de zircônio (pontos amarelos) referente à imagem ampliada, é possível notar zircônio espalhado uniformemente na superfície cerâmica e em aglomerados, comprovando a presença de zircônia impregnada.

Embora o tubo impregnado duas vezes tenha teoricamente uma maior concentração de zircônia na sua estrutura, através dos mapeamentos percebe-se que as partículas de zircônia estão distribuídas de forma mais uniforme no tubo impregnado 
uma vez (figura 26 (b)), provavelmente pelo fato de ter ocorrido duas impregnações e consequentemente duas queimas, aumentando o tamanho dos grãos (zircônia) e contribuindo para a formação dos aglomerados.

A figura 27 mostra a micrografia do tubo impregnado uma vez e queimado a $900^{\circ} \mathrm{C}$ e o mapeamento de zircônio respectivo. Observa-se através do mapeamento à direita da imagem, que nano partículas de zircônia (pontos em verde) ficaram distribuídas sobre a superfície do suporte (alumina) mais uniformemente do que no material impregnado e calcinado a $600^{\circ} \mathrm{C}$ (figura 26).

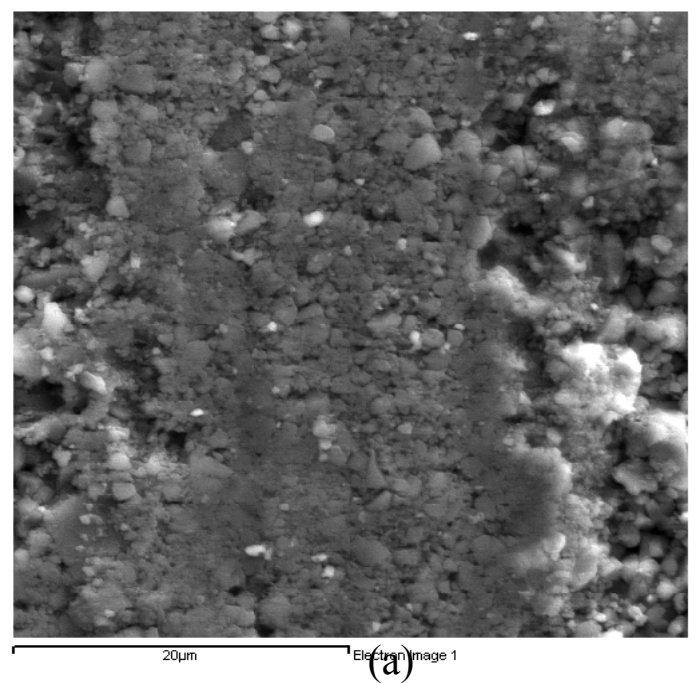

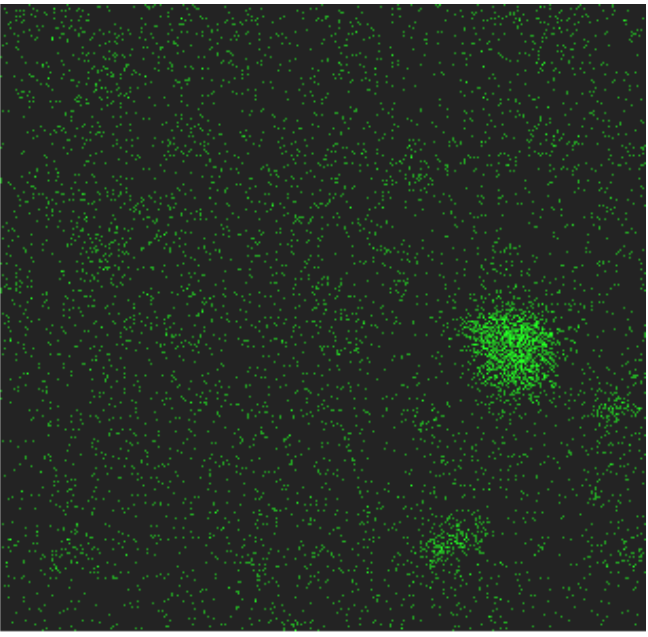

(b)

Figura 27. Análise morfológica do material cerâmico tubular impregnado. (a) tubo impregnado 1 vez a $900^{\circ} \mathrm{C}$ e respectivo mapeamento (b).

Isso implica em uma maior área de contato entre a zircônia e a emulsão. A razão área/volume de uma partícula (considerando uma forma esférica) pode ser dada como 3/4r (raio), quanto maior o raio da partícula ou esfera, menor a razão área/volume, ou seja; embora a partícula ou aglomerado de partículas ocupe um grande volume, a área de contato (ou superficial) será pequena, como representa a figura 28. 


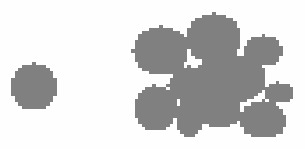

Figura 28. Representação de uma partícula e um aglomerado de partículas que podem se formar na estrutura micro porosa tubular.

Os vazios nas interfaces do aglomerado fazem com que a área de contato diminua, tornando menos efetiva a interação entre a superfície do material e o líquido que irá interagir com ele. Ao passo que uma maior área de contato (entre partículas de zircônia e a mistura) poderá refletir no desempenho do processo de separação. Talvez por isso, o permeado referente ao tubo impregnado duas vezes tenha apresentado altos valores de TOC em relação aos outros tubos.

A figura 29 mostra os espectros na região dos raios-x correspondente à figura 26 e 28, através desses espectros é possível encontrar quais elementos estão presentes na amostra e em que proporção.

O espectro apresentado na figura 29 (a), corresponde à figura 26 (a), no qual é possível observar a presença do alumínio (em maior proporção), zircônio, magnésio e oxigênio, outros elementos foram detectados, mas em proporções pouco significativas. Destes, os elementos de maior interesse são o alumínio (que está na composição de grande parte da estrutura dos tubos devido à alumina) e o zircônio (devido à zircônia impregnada).

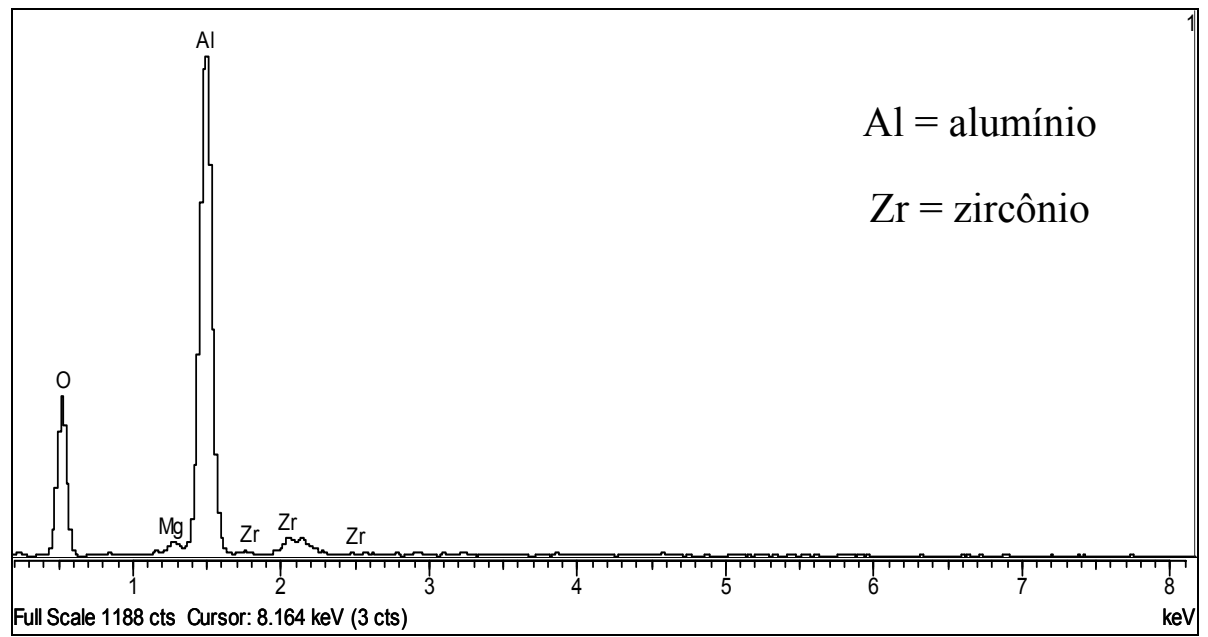

(a) 


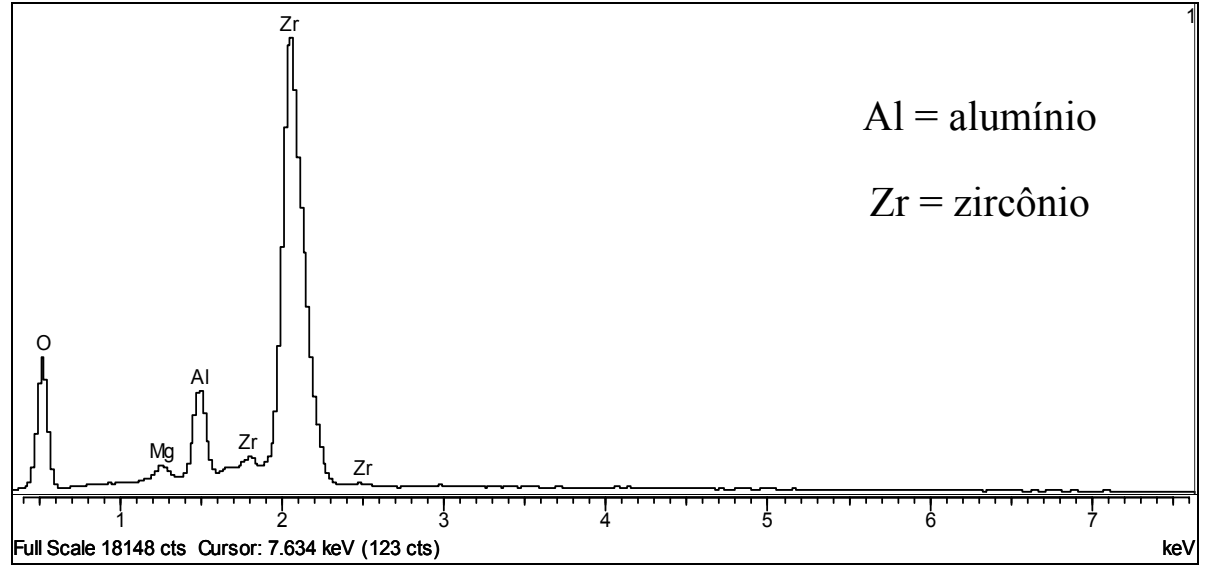

(b)

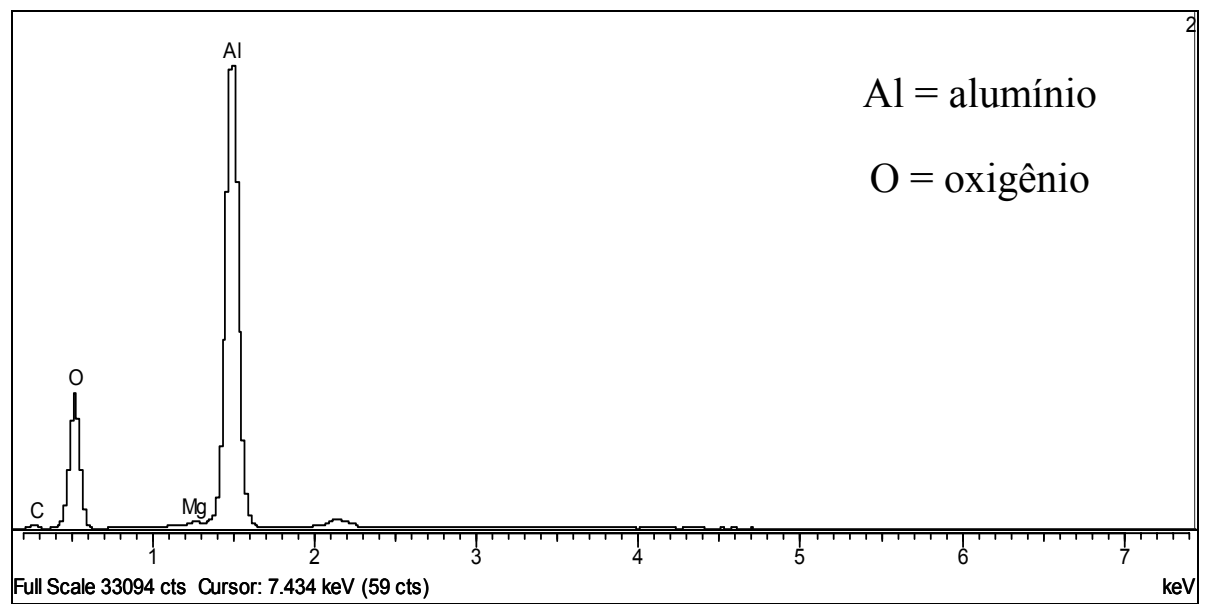

(c)

Figura 29. Espectros dos raios-x realizados através do microscópio eletrônico de varredura. (a) espectro respectivo à fig. 4.17 (a); (b) espectro respectivo à fig. 4.17 (b) no ponto 1; (c) espectro respectivo à fig. 4.17 (b) no ponto 2.

Os espectros da figura 29 (b) e (c) correspondem à figura 26 (c), onde no ponto 1, há uma alta concentração de zircônia (aglomerado), e o respectivo espectro mostra um alto pico referente ao zircônio (figura 29 (b)), já no ponto 2, há um pico alto referente ao alumínio, devido a própria composição da estrutura tubular. A composição química referente à figura 29 (a) foi: 45,61\% (alumínio), 4,21\% (zircônio), 50,18\% (oxigênio) e 0,7\% (magnésio); na figura 29 (b): 4,32\% (alumínio), 53,91\% (zircônio), 0,81\% (magnésio) e 40,95\% (oxigênio); na figura 29 (c): 45,52\% (alumínio), 0,26\% (magnésio), 48,13\% oxigênio e 6,09\% (carbono).

A figura 30 mostra a análise de difração de raios-X para o material (solução de citrato de zircônio calcinada e tratada termicamente para a formação do óxido de zircônio-zircônia) calcinado em temperaturas de 600 e $900^{\circ} \mathrm{C}$. Os difratogramas (figura. 
30) ilustra que os picos estão bem definidos tanto para o material calcinado a $600^{\circ} \mathrm{C}$ como para $900^{\circ} \mathrm{C}$, indicando uma boa cristalinidade da zircônia (em ambas as fases encontradas). Observa-se que o material calcinado a $600^{\circ} \mathrm{C}$, só obteve uma fase cristalina para a zircônia; a monoclínica; enquanto que o material calcinado a $900^{\circ} \mathrm{C}$, demonstrou uma mistura de fases para a zircônia; monoclínica e cúbica.

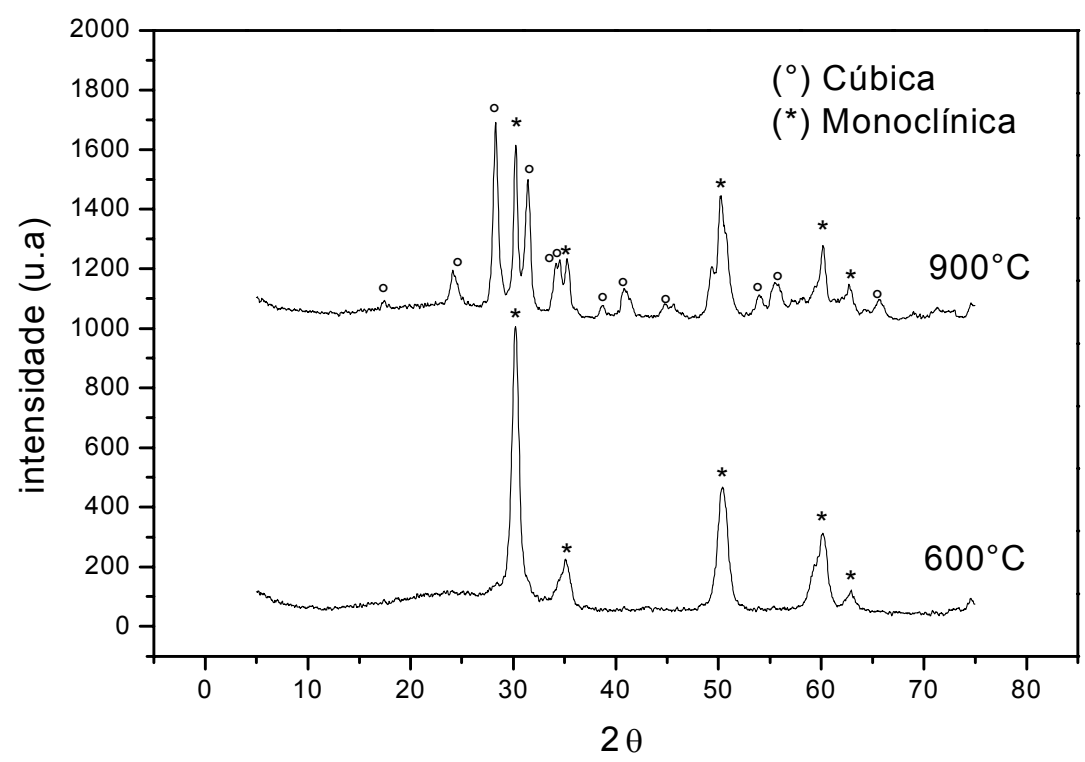

Figura 30. Difratogramas de raios-X para amostras de zircônia provenientes da solução precursora calcinada e tratada termicamente em temperaturas de 600 e $900^{\circ} \mathrm{C}$.

Sabendo que houve então uma mudança na estrutura cristalina da zircônia com o aumento da temperatura de calcinação, pode-se dizer que no material impregnado e calcinado a $900^{\circ} \mathrm{C}$ (tubo cerâmico microporoso com presença de zircônia), existe a mudança de fase da zircônia ou a mistura de fases da mesma, indicando a possível variação nos resultados obtidos para o processo em estudo (descritos anteriormente), devido à presença da fase cúbica ou devido à mistura das duas fases.

\subsection{Caracterização da Mistura e sua Interação com o Meio Filtrante}

As fotografias digitais de uma amostra da emulsão água e óleo de girassol (1\%) ilustradas a seguir (figura 31) foram obtidas através de um microscópio óptico de campo 
claro, acoplado a um sistema de aquisição de imagens e câmera de vídeo. As imagens foram ampliadas 75 e 150 vezes, e um software (Image Pro-plus versão 3.0) foi usado para análise de várias imagens, a fim de se caracterizar a mistura em estudo pela distribuição do tamanho médio (diâmetro médio) das gotículas de óleo presentes na mesma. Neste trabalho, emulsões não foram produzidas com tamanho de gotículas específico.

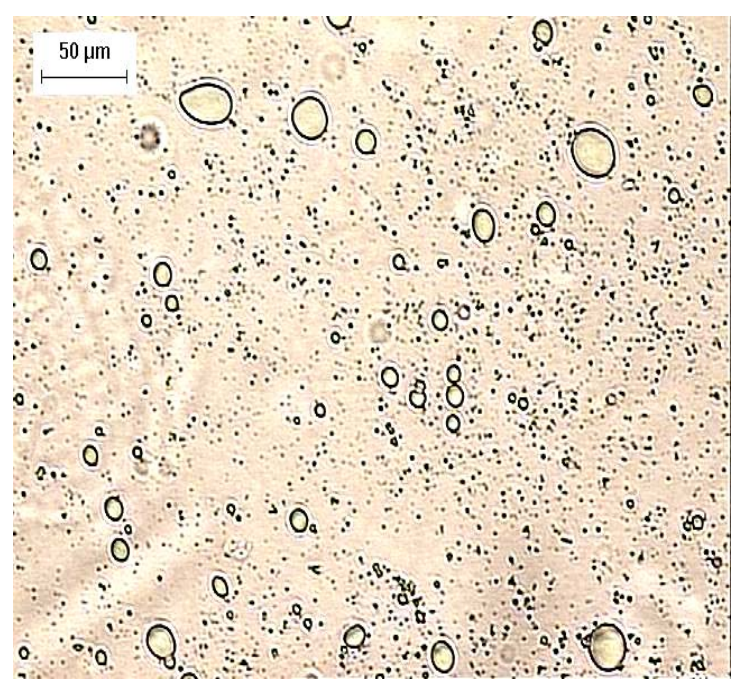

(a)

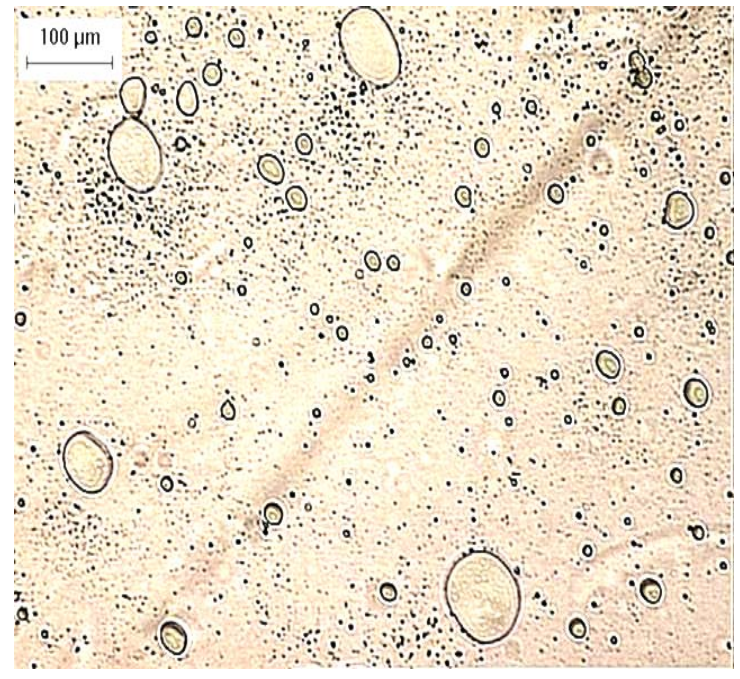

(b)

Figura 31. Imagens da emulsão (concentrado) tiradas através de microscópio óptico com aumento de 150x (a) e $75 x(b)$

A figura 32 ilustra a distribuição do tamanho das gotículas (diâmetro) para uma amostra do concentrado, a contagem das gotículas foi feita através de um software (Image Pro-plus), depois da calibração e tratamento de cinco imagens diferentes (como as imagens da figura 31). O gráfico para a distribuição do tamanho das gotas mostra que o diâmetro médio das gotículas é de 13,67 $\mu \mathrm{m}$ para a mistura em estudo, esse tamanho caracteriza uma emulsão, conforme descrito anteriormente, o tamanho das gotículas de uma emulsão normalmente excede $0,1 \mu \mathrm{m}$ de diâmetro. 


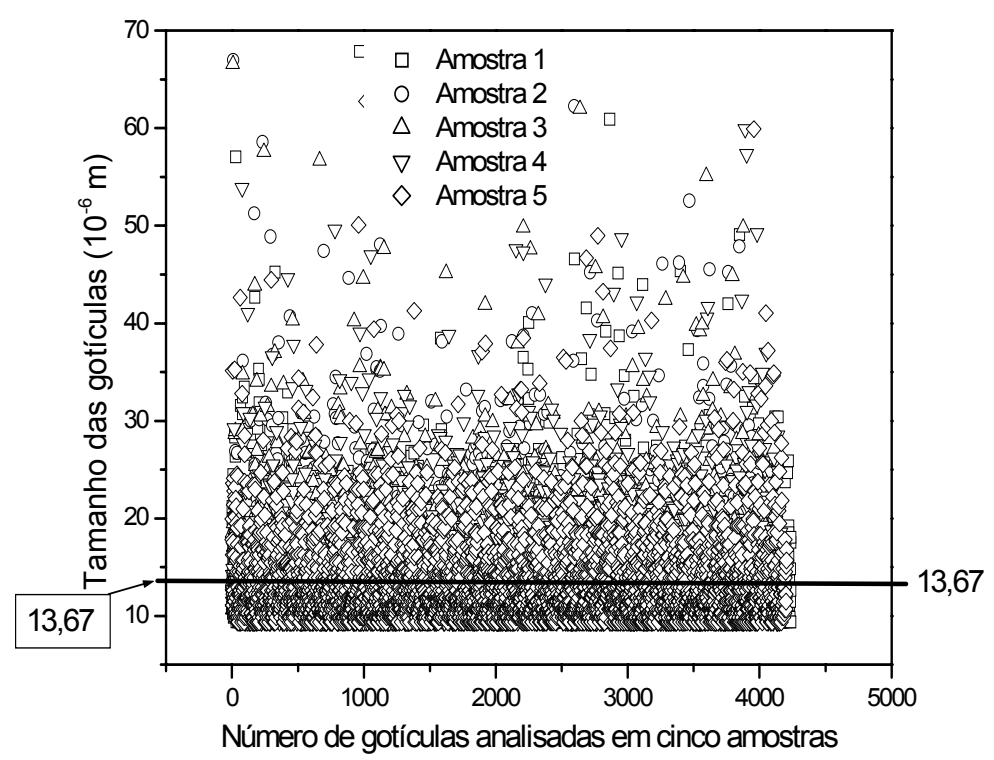

Figura 32. Distribuição do tamanho das gotículas de óleo presentes na mistura água/óleo (1\%).

As figuras 33 a 35 apresentam as imagens tiradas com câmera CCD para posterior análise do ângulo de contato (através do software Surftens 3.0) entre o líquido e o material cerâmico com e sem impregnação. Este tipo de análise poder acrescentar no entendimento da natureza do meio micro-poroso em relação à mistura que está sendo processada, ou seja, se o material micro-poroso modificado quimicamente está ou não agregando propriedades hidrofóbicas (afinidade ao óleo) ou hidrofílicas (afinidade a água).

Conforme a literatura já citada, materiais hidrofóbicos tendem a apresentar altos ângulos de contato $\left(>100^{\circ}\right)$, enquanto outros materiais e especialmente hidrofilizados apresentam baixos valores $\left(<30^{\circ}\right)$. A análise apresentada é relativamente qualitativa, pois não reflete as condições fluidodinâmicas do processo. A análise de imagens foi realizada na pressão atmosférica e sem transporte convectivo da mistura.

A figura 33 mostra a interação entre a mistura emulsificada, cada componente da mistura - água e óleo, com o material micro-poroso impregnado uma vez e queimado a $600^{\circ} \mathrm{C}$. As medidas do ângulo de contato para as imagens 33 (a), 33 (b) e 33 (c) foram: $42,37^{\circ}, 25,86^{\circ}$ e $55,74^{\circ}$; respectivamente. 


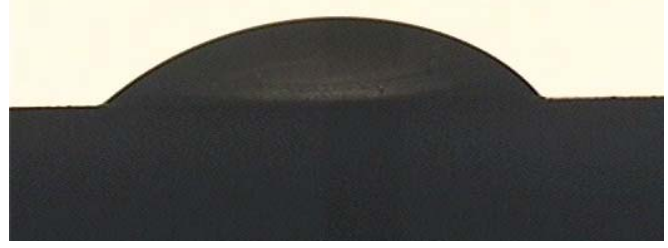

(a)

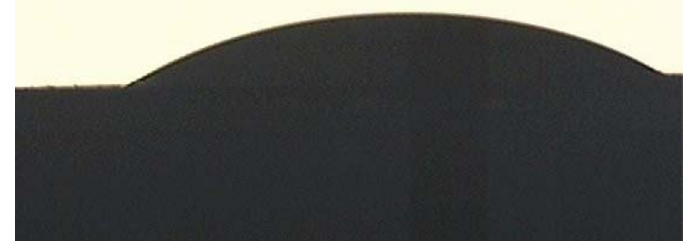

(b)

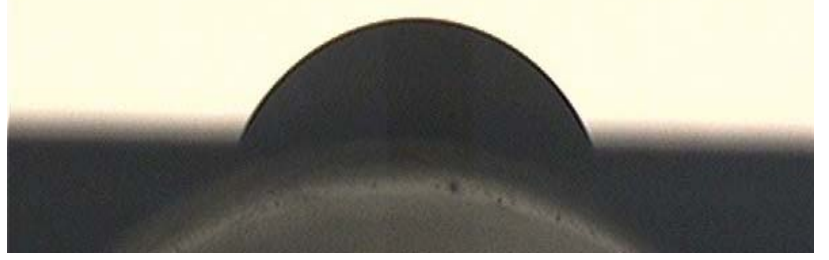

(c)

Figura 33. Imagens captadas com câmera CCD para medição do ângulo de contato, entre o líquido e o material impregnado: água e tubo impregnado 1 vez a $600^{\circ} \mathrm{C}$ (a); óleo e tubo impregnado 1 vez a $600^{\circ} \mathrm{C}$ (b); emulsão e tubo impregnado $1 \mathrm{vez}$ a $600^{\circ} \mathrm{C}$ (c).

É possível observar que o óleo teve um melhor espalhamento sobre a superfície cerâmica impregnada (figura 33 (b)) do que a água, por isso um menor valor para o ângulo de contato; o que implica em uma menor tensão superficial. Se o óleo se espalha melhor sobre a superfície do material do que a água, isso implica que as interações superficiais são predominantes com o óleo, em relação à água, tornando o material cerâmico impregnado mais hidrofóbico do que hidrofílico. Como a mistura água e óleo (figura 33 (c)), que possui proporção menor em óleo (1\%), é de se esperar que o seu comportamento seja parecido com o da água, talvez por isso, tenha um maior ângulo de contato entre a emulsão e a superfície.

Para o tubo impregnado uma vez e queimado a $900^{\circ} \mathrm{C}$, o comportamento dos líquidos (água, óleo e emulsão) em relação ao material impregnado é semelhante ao tubo impregnado e queimado a $600^{\circ} \mathrm{C}$. .As medidas do ângulo de contato para as imagens 34 (a), (b) e (c) foram: $73,91^{\circ}, 21,77^{\circ}$ e $73,42^{\circ}$; respectivamente. 


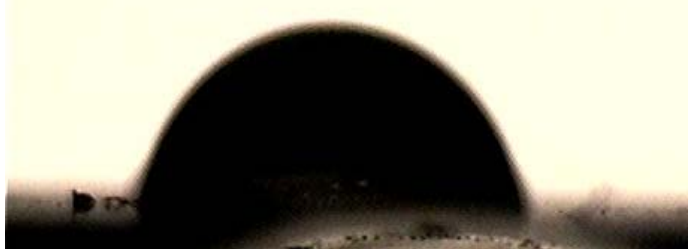

(a)

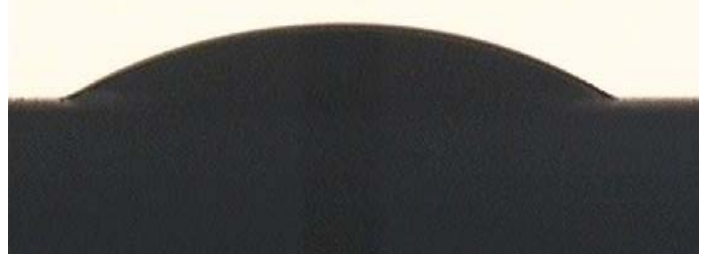

(b)

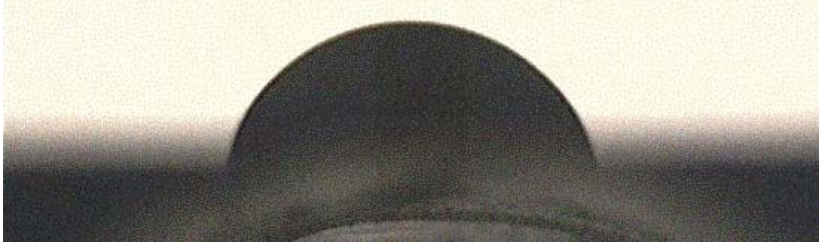

(c)

Figura 34. Imagens captadas com câmera CCD para medição do ângulo de contato, entre o líquido e o material impregnado: água e tubo impregnado 1 vez a $900^{\circ} \mathrm{C}$ (a); óleo e tubo impregnado 1 vez a $900^{\circ} \mathrm{C}$ (b); emulsão e tubo impregnado 1 vez a $900^{\circ} \mathrm{C}$ (c).

Como no caso anterior (figura 33 (b)), o óleo espalha-se mais sobre a superfície do material do que a água (figura 34 (a) e (b)), induzindo um ângulo de contato menor, isso faz com que o material impregnado tenha um caráter hidrofóbico. Acredita-se que por isso o tubo impregnado e queimado a $900^{\circ} \mathrm{C}$, apresentou melhores resultados em relação ao TOC do permeado, devido ao material ter retido uma maior quantidade de óleo em relação ao material dos outros tubos. Esse caráter hidrofóbico pode ter sido induzido com a mudança na estrutura cristalina da zircônia (mistura das fases monoclínica e cúbica).

Os ângulos de contato medido para as imagens 35 (a), (b) e (c) foram: 98,16², $35,75^{\circ}, 51,70^{\circ}$; respectivamente. $\mathrm{O}$ material não impregnado apresenta um comportamento semelhante aos outros dois materiais, percebe-se através das imagens abaixo que o óleo se espalha sobre a superfície cerâmica de modo mais acentuado que a água. Isso torna o material mais hidrofóbico do que hidrofílico. 


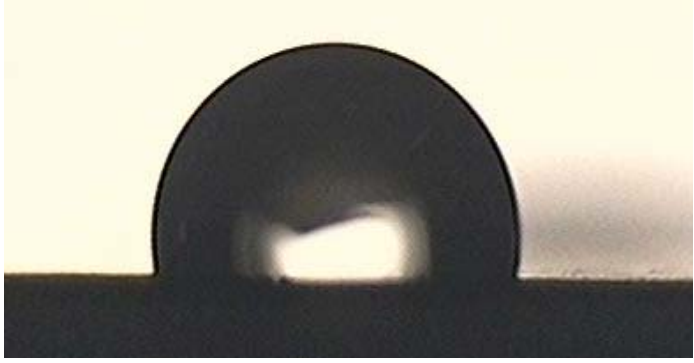

(a)

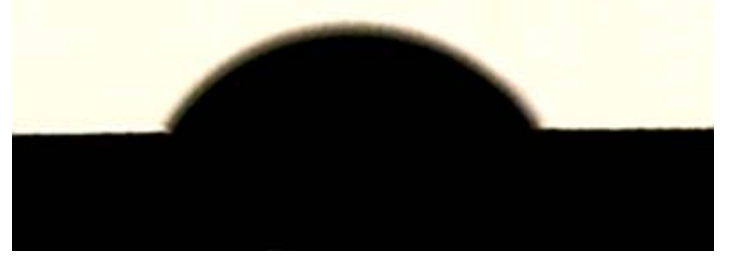

(b)

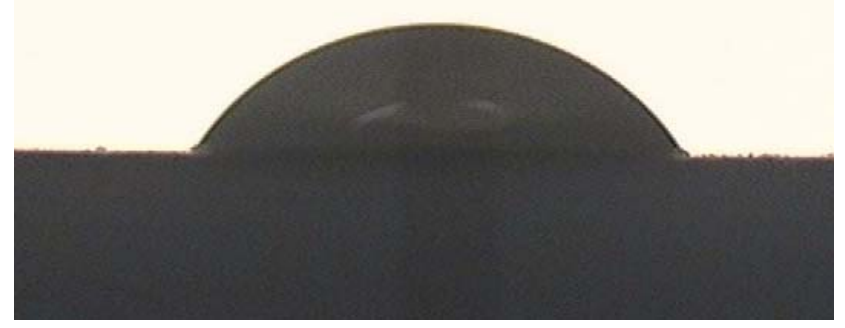

(c)

Figura 35. Imagens captadas com câmera CCD para medição do ângulo de contato, entre o líquido e o material não impregnado: água e tubo não impregnado (a); óleo e tubo não impregnado (b); emulsão e tubo impregnado (c).

Se ângulo de contato interfere na tensão superficial e para formar uma emulsão é necessário diminuir a tensão superficial entre as fases, para desemulsificar o contrário também ocorre. Neste caso, a maior tensão superficial é obtida para a fase aquosa (maior ângulo de contato), por isso no processo de desemulsificação em estudo, obtémse um permeado praticamente isento de óleo para todos os tubos (exceto o tubo impregnado duas vezes em que os valores de TOC foram maiores). De modo que o meio micro-poroso filtrante funciona como um meio hidrofóbico que retém o óleo e repele a água. 


\section{CONCLUSÕES E PLANOS FUTUROS}

A partir deste trabalho de pesquisa do processo de micro-filtração tangencial aplicado na desemulsificação de emulsões água-óleo de girassol com tubos cerâmicos micro-porosos, foi possível concluir o seguinte:

O método de impregnação de zircônia mostrou-se eficaz através da análise de microscopia eletrônica de varredura (MEV) na micro-estrutura cerâmica. Foi constatada a presença de nano partículas dispersas em grande parte do suporte micro-poroso (alumina).

Quanto aos resultados experimentais da análise do processo de micro filtração, um bom desempenho pôde ser observado para todos os tubos testados, mas em especial para o tubo impregnado uma vez e queimado a $900^{\circ} \mathrm{C}$. Isso indica que tanto a concentração de zircônia impregnada no tubo, como as temperaturas usadas durante o tratamento térmico (após a impregnação), podem influenciar no desempenho do processo quanto ao fluxo trans-membrana. Variações nos parâmetros fluidodinâmicos também foram estudadas, e constatou-se que os maiores fluxos foram obtidos nos maiores Reynolds e nas maiores pressões trans-membrana.

Uma influência menos favorável no desempenho da desemulsificação foi observada nos tubos micro-porosos com maior concentração de zircônia. Os resultados indicaram neste caso os menores valores de fluxo trans-membrana e na qualidade do permeado, os maiores valores de TOC.

Em relação ao processo de transferência de massa analisado através do adimensional de Sherwood (Sh), observou-se que os maiores valores de "Sh" entre os tubos impregnados uma e duas vezes e queimados a 600 e $900^{\circ} \mathrm{C}$, o tubo impregnado e queimado a $900^{\circ} \mathrm{C}$ obteve os maiores valores de Sh. Portanto, a temperatura após impregnação pode ser considerada um fator relevante no transporte de massa durante o 
processo de separação, devido a propriedades físico-químicas superficiais do meio micro-poroso ou a efeitos de superfície entre a mistura e a zircônia impregnada. Parâmetros como o número de Reynolds e a pressão trans-membrana influenciaram nos valores de Sh, sendo que para a maioria dos tubos ensaiados os maiores valores de Sh foram alcançados nas maiores pressões trans-membrana e maiores Reynolds.

Com respeito à qualidade do permeado pôde ser observado através das análises de TOC que o melhor resultado para o processo dinâmico foi obtido para o tubo impregnado e queimado a $600^{\circ} \mathrm{C}$, e para o processo estático a $900^{\circ} \mathrm{C}$. Portanto, é possível concluir que os tubos que foram impregnados com zircônia podem influenciar positivamente no processo de separação de misturas água-óleo vegetal, dentro das condições estudadas. Uma mudança na temperatura durante o tratamento térmico (de $600^{\circ} \mathrm{C}$ para $900^{\circ} \mathrm{C}$ ), pode ser responsável pela melhora na desemulsificação, devido à mudança na estrutura cristalina da zircônia, conforme comprovado pela análise de difratometria de raios-X.

As análises de $\mathrm{pH}$ e condutividade elétrica demonstraram que a qualidade do permeado para os tubos impregnados uma vez foram melhores do que a do tubo sem impregnação e a do tubo impregnado duas vezes, pois os valores de $\mathrm{pH}$ encontrados foram próximos de 7,00 ( $\mathrm{pH}$ neutro) e muito próximos do $\mathrm{pH}$ da água de torneira (em torno de 6,00). Assim como os valores de condutividade elétrica, que se mostraram menores para o tubo impregnado uma vez e queimado a $600^{\circ} \mathrm{C}$ e maiores para o tubo impregnado duas vezes e queimado a $600^{\circ} \mathrm{C}$. Isso indica que uma baixa condutividade implica numa baixa concentração de íons dissolvidos no permeado, talvez devido a interações físico-químicas entre a estrutura do tubo e a mistura, conduzindo a um permeado menos concentrado de íons ou sais, porém de excelente qualidade para reuso.

Devido aos resultados apresentados neste trabalho, conclui-se que os tubos impregnados uma vez e queimados a $600^{\circ} \mathrm{C}$ e $900^{\circ} \mathrm{C}$, mostraram um comportamento hidrofóbico, retendo uma quantidade significativa de óleo (quase 100\%) em comparação com outros ensaiados e a membrana comercial. Em particular a membrana comercial com tamanho de poros $(0,6 \mu \mathrm{m})$ muito próximo aos tubos micro-porosos. $(0,5$ $\mu \mathrm{m})$ não apresentou bons resultados, devido a grande concentração de óleo no permeado.

Como planos de futuras pesquisas que podem dar continuidade no tema deste trabalho, pode-se indicar: 
i) desenvolver a técnica de impregnação, em busca da formação de um filme fino de óxido de zircônio sobre a superfície cerâmica micro-porosa. Analisar o desempenho da presença do filme de zircônia, usando como objeto de separação uma mistura água-óleo mineral e água e óleo-vegetal em concentrações diferentes;

ii) avaliar o efeito causado no processo de desemulsificação por filtração tangencial e a mudança na estrutura cristalina da zircônia, já que os tubos impregnados a $900^{\circ} \mathrm{C}$ apresentaram duas estruturas diferentes (monoclínica e cúbica). É de interesse verificar se os resultados obtidos são referentes à existência dessas duas estruturas juntas ou somente da estrutura cúbica (que só aparece quando o material é impregnado e queimado a $900^{\circ} \mathrm{C}$ e não a $600^{\circ} \mathrm{C}$ ).

iii) Sintetizar na matriz cerâmica dispersões de pequenas quantidades de zircônia nanométrica, propiciando a inibição do crescimento de grãos durante a sinterização, e também, a tendência das nanopartículas formarem aglomerados (PIERRI et al, 2005). Essa matéria-prima seria produto para a fabricação de tubos que seriam testados no processo de desemulsificação de misturas água-óleo mineral. 


\section{REFERÊNCIAS BIBLIOGRÁFICAS}

ABOISSA ÓLEOS VEGETAIS. Informações sobre a semente e o óleo de girassol. Disponível em: <http://www.aboissa.com.br>. Acesso em: mai. 2005.

BELFORT, G., DAVIS, R. H. e ZYDNEY, A. L. (1994). The behavior of suspensions and macromolecular solutions in crossflow microfiltration. Journal of Membrane Science, 96. p. 1-58.

BENITO, J. M. et al. (1999). Integrated process for the removal of emulsified oils from effluents in the steel industry. Separation Science and Technology, 34(15). p. 3031-43.

CASTELlAN, G. (1986). Fundamentos de Físico-Química. LTC-Livros Técnicos e Científicos Editora S.A. Rio de Janeiro-RJ. $1^{\circ}$ Edição.

OLIVEIRA, A. G. et al. (2004). Microemulsões: Estrutura e Aplicações como sistema de liberação de fármacos. Revista Química Nova, 27(1). p. 131-38.

CHANG, C. -H., GOPALAN, R. e LIN, Y. S. (1994). A comparative study on thermal and hydrothermal stability of alumina, titania, and zirconia membranes, Journal of Membrane Science, 91. p. 27-45.

CHERYAN, M. (1998). Ultrafiltration and Microfiltration - Handbook. Technomic Publishing Company, Lancaster, Pennsylvania.

CZEKAJ, P., LÒPEZ, F. e GÜELL, C. (2000). Membrane fouling by turbidity constituents of beer and wine: characterization and prevention by means of infrasonic pulsing. Journal of Food Engineering. 49. p. 25-36. 
CHO, C. W., LEE, D. Y. e KIM, C. W. (2003). Concentration and purification of soluble pectin from mandarin peels using crossflow microfiltration system, Carbohydrate Polymers, 54. p. 21-26.

DE LANGE, R. S. A. et al. (1995). Journal Membrane Science, 99(27).

DEEN, W. M. (1998). Analysis of Transport Phenomena, Oxford University Press, New York.

FONTES, S. R. (2005). Mass transfer in microfiltration with laminar and turbulent flow of macromolecular solutions, Journal of Membrane Science, 249. p. 207-211.

FORTULAN, C. A. e PURQUEIRO, B. de M. (1995). Seleção, propriedades e processamento de materiais não metálicos para projetos mecânicos. Serviço gráfíco EESC-USP. São Carlos, 1995. p. 51-53.

HONG, A., FANE, A.G. e BURFORD, R. (2003). Factors affecting membrane coalescence of stable oil-in-water emulsions, Journal of Membrane Science, 222. p. 1939.

HOTRUM, N. E. et al. (2004). Spreading of partially crystallized oil droplets on air/water interface, Colloids and Surfaces A: Physicochem. Eng. Aspects, 240. p. 83-92.

HYUN, S. H. e KIM, G. T. (1997). Synthesis of Ceramic Microfiltration Membranes for Oil/Water Separation, Separation Science and Technology, 32(18). p. 2927-2943.

JOSCELYNE, S. M. e TRÄGARDH, G. (2000). Membrane emulsification - a literature review, Journal of Membrane Science, 169. p. 107-117.

KINUGASA, T. e WATANABE, K. (1996). An evaluation of effective diffusivity in (w/o) emulsion drops. Chemical Engineering Science, 52(8). p. 1393-1397.

KOLTUNIEWICZ, A.B. e FIELD, R. W. (1996). Process factors during removal of oilwater emulsions with cross-flow microfiltration. Desalination, 105 (1-2). p. 79-89. 
KOLTUNIEWICZ, A. B., FIELD, R. W. e ARNOT, T. C. (1995). Cross-flow and deadend microfiltration of oily-water emulsion. Part I: Experimental study and analysis of flux decline, Journal of Membrane Science, 102. p. 193-207.

KÖSEOGLU, S. S., LAWHON, J. T. e LUSAS, E. W. (1990). Membrane processing of crude vegetable oils: pilot plant scale removal of solvent from oil micellas. Journal Am. Oil Chemist's Soc. 67(5) 315.

LOPEZ, R. V., ELMALEH, S. e GHAFFOR, N. (1995). Cross-flow Ultrafiltration of Hydrocarbon Emulsions. Journal of Membrane Science, 102. p. 55-64.

MENON, V.B., WASAN, D.T. (1985). Demulsification, in: P. Becher (Ed.), Encyclopedia of Emulsification Technology, Marcel Dekker, New York, p. 1-75.

MISHCHUK, N. A., SANFELD, A. e STEINCHEN, A. (2004). Interparticle interactions in concentrate water-oil emulsions, Advances in Colloid and Interface Science, 112. p. 129-157.

MICROMETICS BRASIL. Porosimetria por intrusão de mercúrio. Disponível em: http://www.micrometics.com.br. Acesso em: jun. 2005.

MOREIRA, J. C. (1994). Formação de emulsões e microemulsões do tipo óleo em água (o/a) com óleo de soja/ José Carlos Moreira. Monografia. Instituto de Química de São Carlos, Universidade de São Paulo, São Carlos. 1994. Monografia

NABI, N., AIMAR, P. e MEIRELES, M. (2000). Utrafiltration of an olive oil emulsion stabilized by an anionic surfactant, Journal of Membrane Science, 166. p. 177-188.

NAZZAL, F. F., WIESNER, M. R. (1996). Microfiltration of oil-water emulsions. Water Environment Research, 68(7). p. 1187-91.

OHLWEILER, O. A. (1976). Química analítica quantitativa. Rio de Janeiro: Livros Técnicos e Científicos. Vol. 1. $2^{\circ}$ ed. 
OLIVEIRA, A. G. et al. (2004). Microemulsões: estrutura e aplicações como sistema de liberação de fármacos, Química Nova, 27(1). p. 131-138.

PARIS, J. et al. (2002). Transport Phenomena in ultrafiltration: a new two-dimensional model compared with classical model, Journal of Membrane Science, 207. p. 43-58.

PIERRI, J. J. et al. (2005). Dispersão de nanopartículas de $\mathrm{ZrO}_{2}$ visando produção de nanocompósitos de $\mathrm{ZrO}_{2}$ em matriz de $\mathrm{AlO}_{3}$. Associação Brasileira de Cerâmica, 51. p. 08-12.

PSOCH, C. et al. (2004). Waste oil conditioning via microfiltration with ceramic membranes in cross flow, Journal of Membrane Science 245. p. 113-121.

QUEIROZ, V. M. S. (2004). Estudo experimental do escoamento e da concentração de mistura no processo de filtração tangencial de suspensões macromoleculares. Dissertação (mestrado em Engenharia Mecânica) - Escola de Engenharia de São Carlos, Universidade de São Paulo, São Carlos. 2004.

RADHARANI DAS e DUTTA, B. K. (1999). Permeation and Separation Characteristics of Supported Alumina and Titania Membranes, Separation Science and Technology, 34(4). p. 609-625.

RICHERSON, D. W. (1992). Modem ceramic engineering. Properties, Processing, and Use in Design. Ed. MARCEL DEKKER, INC. New York, USA.

RIPPERGER, S. e ALTMANN, J. (2002). Crossflow microfiltration - state of the art. Separation and Purification Thecnology, 26, p. 19-31.

SCOTT, K. (1995). Handbook of industrial membranes. Elsevier Science Publishers, Oxford.

SONDHI, R. et al. (2003). Applications and benefits of ceramic membranes, Membrane Technology. Pall Corp, 1750. Filter Drive, De Land, Florida, USA. 
SRIJAROONRAT, P., JULIEN, E., AURELLE, Y. (1999). Unstable secondary oil/water emulsion treatment using ultrafiltration: fouling control by backflushing, Journal of Membrane Science, 159. p. 11-20.

STOPKA, J. et al..Microfiltration of beer yeast suspensions through stamped ceramic membranes. Separation and Purification and Technology, v.25, p.535-543.

TEIXEIRA, V. G. et al. (2001). Principais métodos de caracterização da porosidade de resinas à base de divinilbenzeno, Química Nova 24(6). p. 808-818.

TING, J. K. e WU, J. C. S. (1999). Cross-Flow Ultrafiltration of Oil/Water Emulsions Using Porous Ceramic Membrane, Journal of the Chinese Institute of Chemical Engineers, 30(3). p. 207-214.

TSURU, T., SUDOH, T., YOSHIOKA, T. e ASAEDA, M. (2001). Nanofiltration in non-aqueous solutions by porous silica-zirconia membranes, Journal of Membrane Science, 185. p. 253-261.

VIOTTO, L. A. e RIZVI, S. H. S. (1998). Produção de Concentrado de Caseína Diafiltrada (CCD) pelo Processo Cascata usando Membranas Cerâmicas. Revista do Instituto de Laticínios, 53(304). p. 251-263.

VIVIANI, E. (1992). Estudo Experimental da curva de distribuição de vazios de geotexteis não tecidos. Dissertação (mestrado em Engenharia de Estruturas) - Escola de Engenharia de São Carlos, Universidade de São Paulo, São Carlos, 1992.

VENTURINI, V., DORNIER, M. e BELLEVILLE, M. P. (2000). Otimização da microfiltração de suco de laranja em piloto de bancada. In: SINERGIA- II Simpósio em Energia na Agricultura, Botucatu, Unesp/FCA, v.1. p. 267-76.

WU, J. C.S. e LEE, E. H. (1999). Ultrafiltration of soybean oil/hexane extract by porous ceramic membranes, Journal of Membrane Science, 154. p. 251-259.

XIA, L., LU, S. e CAO, G. (2004). Stability and demulsification of emulsions stabilized by asphaltenes or resins, Journal of Colloid and Interface Science, 271. p. 504-506. 
YANG, C., ZHANG, G., XU, N. e SHI, J. (1998). Preparation and application in oilwater separation of $\mathrm{ZrO}_{2} / \alpha-\mathrm{Al}_{2} \mathrm{O}_{3}$ MF membrane, Journal of Membrane Science, 142. p. 235-243.

ZEMAN, L. J. e ZYDNEY, A. L. (1996). Microfiltration and Ultrafiltration - Principles and Applications. Marcel Dekker, New York. 